Keywords: $D W P F, S B 6, H g$, ammonia, hydrogen

Retention: Permanent

\title{
Sludge Batch 6/Tank 40 Simulant Chemical Process Cell Simulations
}

D. C. Koopman

April 2010

Savannah River National Laboratory Savannah River Nuclear Solutions Aiken, SC 29808

Prepared for the U.S. Department of Energy under contract number DE-AC09-08SR22470.

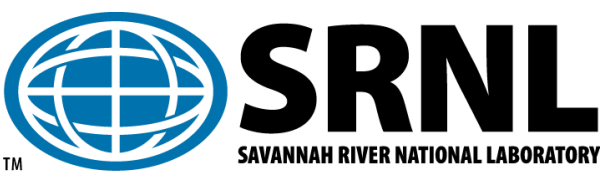


SRNL-STI-2010-00212

Revision 0

\section{DISCLAIMER}

This work was prepared under an agreement with and funded by the U.S. Government. Neither the U.S. Government or its employees, nor any of its contractors, subcontractors or their employees, makes any express or implied:

1. warranty or assumes any legal liability for the accuracy, completeness, or for the use or results of such use of any information, product, or process disclosed; or

2. representation that such use or results of such use would not infringe privately owned rights; or

3. endorsement or recommendation of any specifically identified commercial product, process, or service.

Any views and opinions of authors expressed in this work do not necessarily state or reflect those of the United States Government, or its contractors, or subcontractors.

\section{Printed in the United States of America \\ Prepared for \\ U.S. Department of Energy}


SRNL-STI-2010-00212

Revision 0

\section{REVIEWS AND APPROVALS}

AUTHORS:

D. C. Koopman, Process Technology Programs

Date

TECHNICAL REVIEW:

M. E. Stone, Process Technology Programs

Date

B. R. Pickenheim, Process Technology Programs

Date

APPROVAL:

C. C. Herman, Manager

Date

Process Technology Programs

S.L. Marra, Manager

Date

Environmental \& Chemical Process Technology Research Programs

J. E. Occhipinti, Manager

Date

Waste Solidification Engineering 
SRNL-STI-2010-00212

Revision 0

\section{EXECUTIVE SUMMARY}

Phase III simulant flowsheet testing was completed using the latest composition estimates for SB6/Tank 40 feed to DWPF. The goals of the testing were to determine reasonable operating conditions and assumptions for the startup of SB6 processing in the DWPF. Testing covered the region from 102-159\% of the current DWPF stoichiometric acid equation.

Nitrite ion concentration was reduced to $90 \mathrm{mg} / \mathrm{kg}$ in the SRAT product of the lowest acid run. The $159 \%$ acid run reached $60 \%$ of the DWPF Sludge Receipt and Adjustment Tank (SRAT) limit of $0.65 \mathrm{lb} \mathrm{H}_{2} / \mathrm{hr}$, and then sporadically exceeded the DWPF Slurry Mix Evaporator (SME) limit of $0.223 \mathrm{lb} \mathrm{H}_{2} / \mathrm{hr}$. Hydrogen generation rates peaked at $112 \%$ of the SME limit, but higher than targeted wt\% total solids levels may have been partially responsible for rates seen. A stoichiometric factor of $120 \%$ met both objectives. A processing window for SB6 exists from $102 \%$ to something close to $159 \%$ based on the simulant results. An initial recommendation for SB6 processing is at $115-120 \%$ of the current DWPF stoichiometric acid equation. The addition of simulated Actinide Removal Process (ARP) and Modular Caustic Side Solvent Extraction Unit (MCU) streams to the SRAT cycle had no apparent impact on the preferred stoichiometric factor.

Hydrogen generation occurred continuously after acid addition in three of the four tests. The three runs at $120 \%, 118.4 \%$ with $\mathrm{ARP} / \mathrm{MCU}$, and $159 \%$ stoichiometry were all still producing around $0.1 \mathrm{lb}$ hydrogen/hr at DWPF scale after 36 hours of boiling in the SRAT. The $120 \%$ acid run reached $23 \%$ of the SRAT limit and $37 \%$ of the SME limit. Conversely, nitrous oxide generation was subdued compared to previous sludge batches, staying below $29 \mathrm{lb} / \mathrm{hr}$ in all four tests or about a fourth as much as in comparable SB4 testing.

Two processing issues, identified during SB6 Phase II flowsheet testing and qualification simulant testing, were monitored during Phase III. Mercury material balance closure was impacted by acid stoichiometry, and significant mercury was not accounted for in the highest acid run. Coalescence of elemental mercury droplets in the mercury water wash tank (MWWT) appeared to degrade with increasing stoichiometry. Observations were made of mercury scale formation in the SRAT condenser and MWWT. A tacky mercury amalgam with $\mathrm{Rh}, \mathrm{Pd}$, and $\mathrm{Cu}$, plus some $\mathrm{Ru}$ and $\mathrm{Ca}$ formed on the impeller at $159 \%$ acid. It contained a significant fraction of the available $\mathrm{Pd}, \mathrm{Cu}$, and $\mathrm{Rh}$ as well as about $25 \%$ of the total mercury charged. Free (elemental) mercury was found in all of the SME products.

Ammonia scrubbers were used during the tests to capture off-gas ammonia for material balance purposes. Significant ammonium ion formation was again observed during the SRAT cycle, and ammonia gas entered the off-gas as the $\mathrm{pH}$ rose during boiling. Ammonium ion production was lower than in the SB6 Phase II and the qualification simulant testing. Similar ammonium ion formation was seen in the ARP/MCU simulation as in the $120 \%$ flowsheet run. A slightly higher $\mathrm{pH}$ caused most of the ammonium to vaporize and collect in the ammonia scrubber reflux solution.

Two periods of foaminess were noted. Neither required additional antifoam to control the foam growth. A steady foam layer formed during reflux in the $120 \%$ acid run. It was about an inch thick, but was 2-3 times more volume of bubbles than is typically seen during reflux. A similar foam layer also was seen during caustic boiling of the simulant during the ARP addition. While frequently seen with the radioactive sludge, foaminess during caustic boiling with simulants has been relatively rare. 
Two further flowsheet tests were performed and will be documented separately. One test was to evaluate the impact of process conditions that match current DWPF operation (lower rates). The second test was to evaluate the impact of SRAT/SME processing on the rheology of a modified Phase III simulant that had been made five times more viscous using ultrasonication. 


\section{TABLE OF CONTENTS}

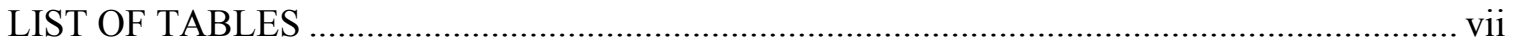

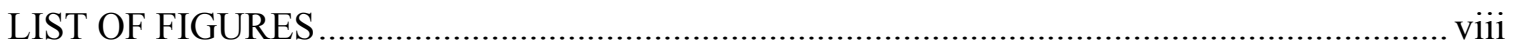

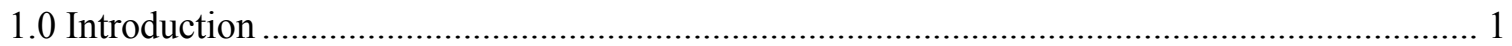

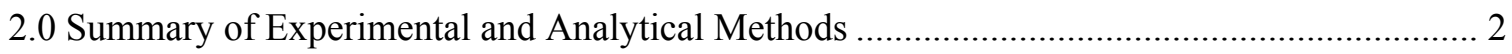

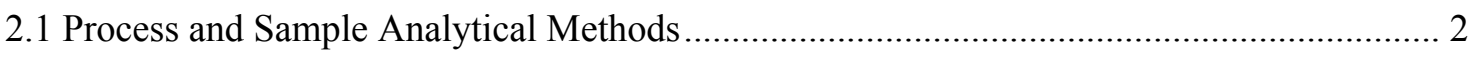

2.2 Simulant Preparation and Characterization..................................................................... 3

2.3 Chemical Process Cell Simulation Details ...................................................................... 5

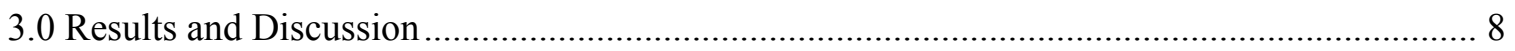

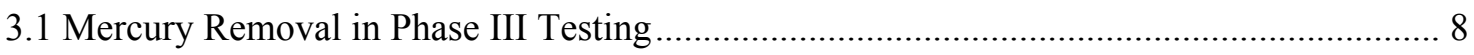

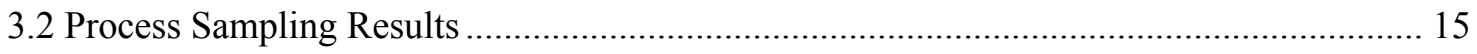

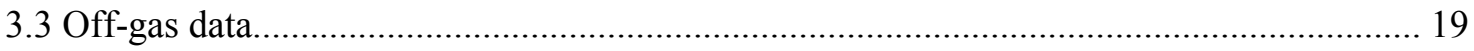

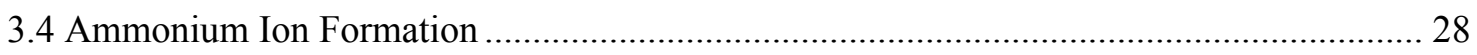

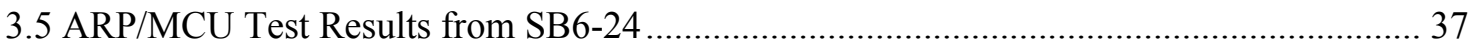

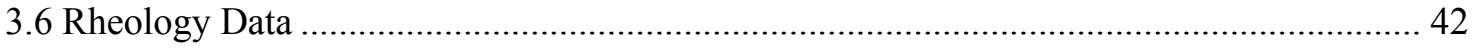

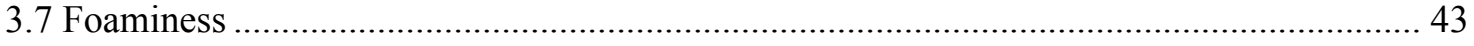

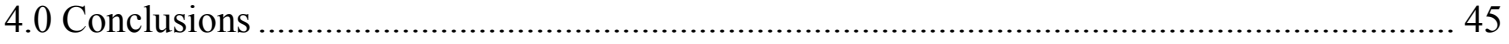

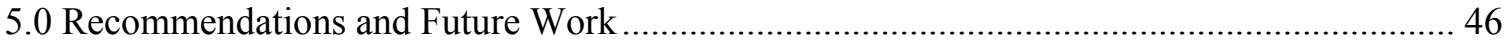

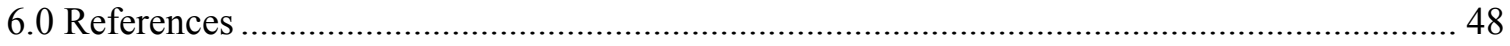

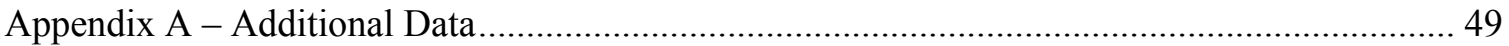




\section{LIST OF TABLES}

Table 1. Selected comparisons of SB6-G blend simulant to previous batches ............................ 2

Table 2. Elemental composition of simulants calcined at $1100^{\circ} \mathrm{C}$, wt $\%$..................................... 4

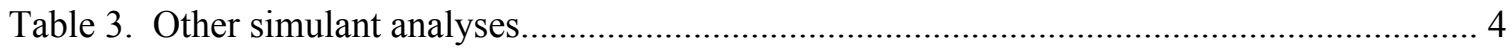

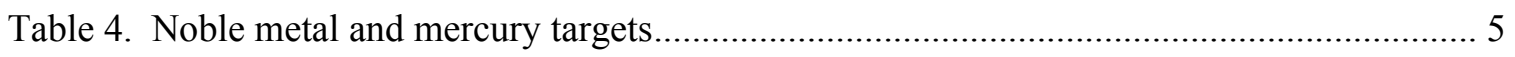

Table 5. Stoichiometric acid calculation results, moles acid/L slurry ......................................... 7

Table 6. Elements dissolved from agitator impeller deposits, $\mathrm{mg} / \mathrm{L}$ acid ................................. 11

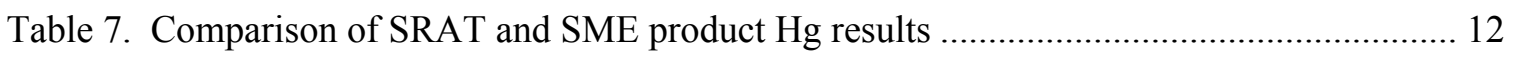

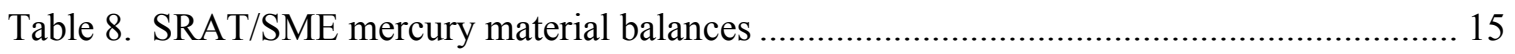

Table 9. Percentages of selected elements in supernate after acid addition ............................... 15

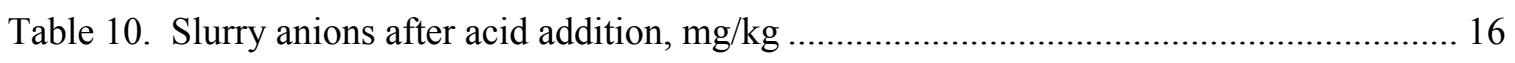

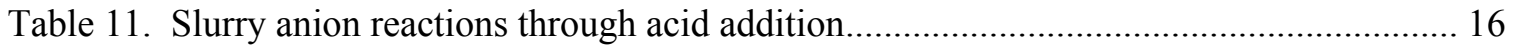

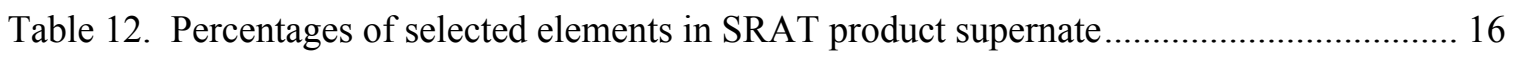

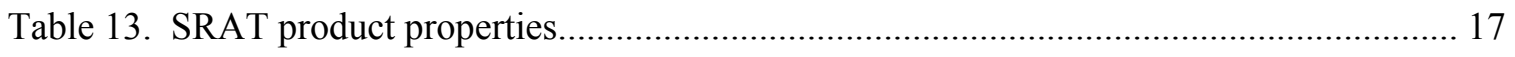

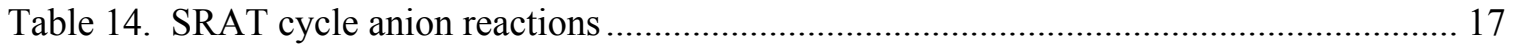

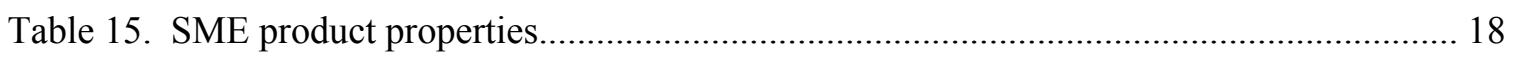

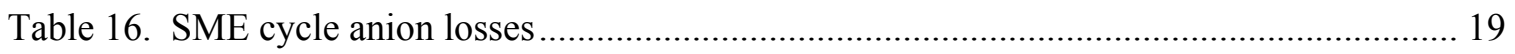

Table 17. Percentages of selected elements in SME product supernate ..................................... 19

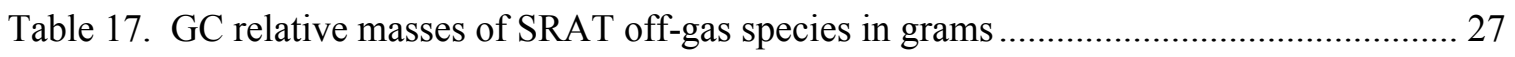

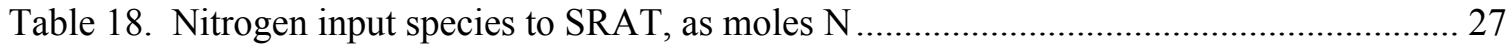

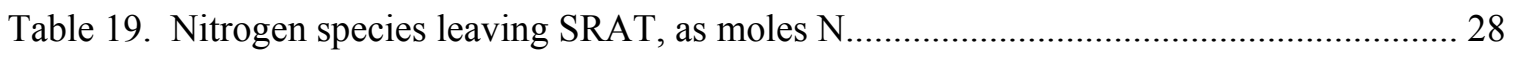

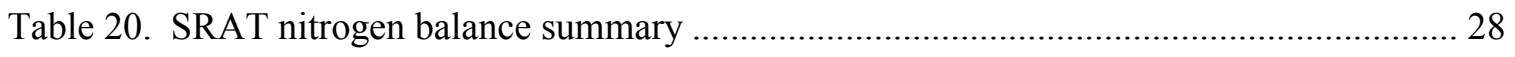

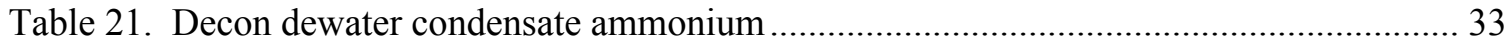

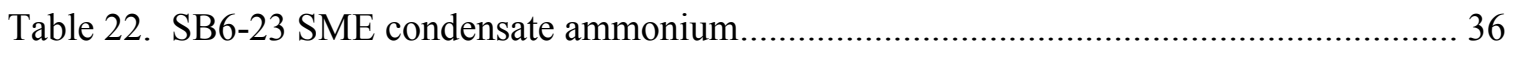

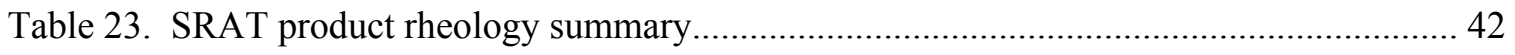

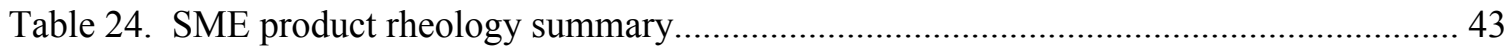

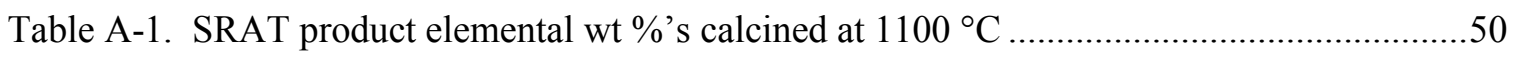

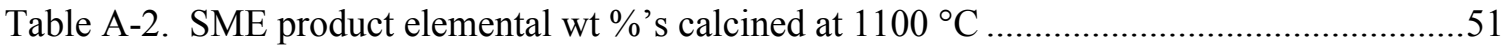


SRNL-STI-2010-00212

Revision 0

\section{LIST OF FIGURES}

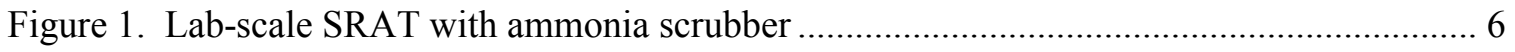

Figure 2. SB6-21 Hg (left), SB6-23 (middle), and SB6-22 Hg (right) ………........................... 8

Figure 3. Mercury collected from the MWWT of SB6-24 (ARP/MCU) ……............................ 9

Figure 4. SB6-23 MWWT mercury-rich deposits ....................................................................... 9

Figure 5. Slurry mercury concentration as a function of time ................................................. 10

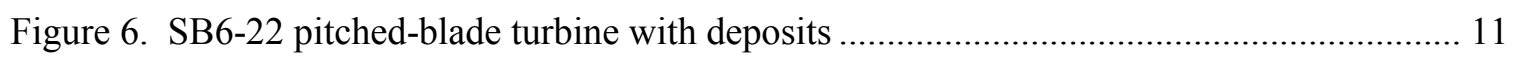

Figure 7. A dried portion of SB6-23 SME product slurry ...................................................... 13

Figure 8. A dried portion of SB6-21 SME product slurry ….................................................. 14

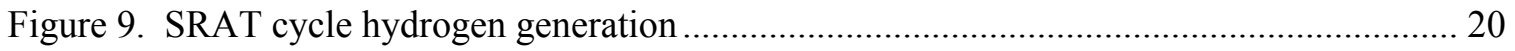

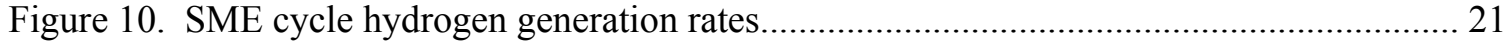

Figure 11. Carbon dioxide during acid addition, dewatering, and early reflux........................... 22

Figure 12. Carbon dioxide generation following formic acid addition ........................................ 23

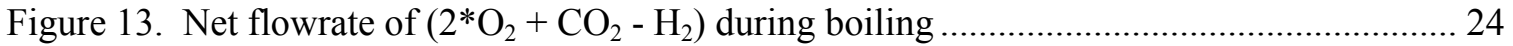

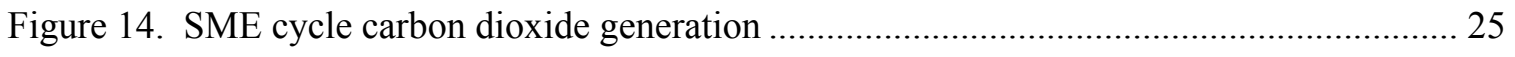

Figure 15. Nitrous oxide during SRAT acid addition and dewatering ..................................... 26

Figure 16. Net flowrate of $\left(2 * \mathrm{O}_{2}+\mathrm{CO}_{2}-\mathrm{H}_{2}\right)$ during boiling in SB6-22 ................................ 30

Figure 17. Expanded timeline development for SB6-22 ammonia ............................................. 31

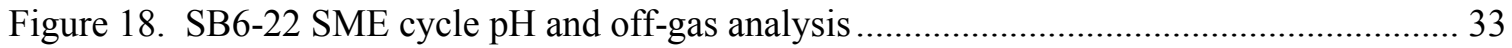

Figure 19. SB6-23 SRAT timeline for nitrate consumption/ammonium formation..................... 35

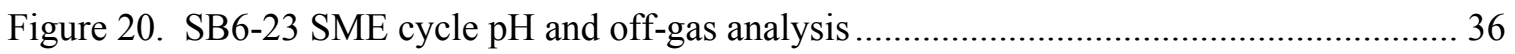

Figure 21. Change in slurry $\mathrm{Hg}$ concentration during SRAT ................................................... 38

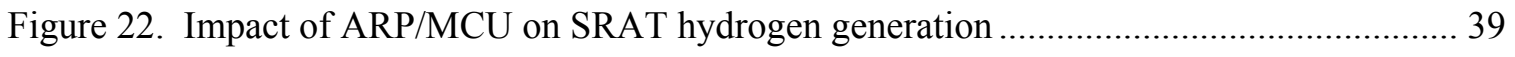

Figure 23. Impact of ARP on $\mathrm{CO}_{2}$ generation during acid addition........................................ 40

Figure 24. Impact of $\mathrm{ARP} / \mathrm{MCU}$ on $\mathrm{CO}_{2}$ generation during boiling ..................................... 40

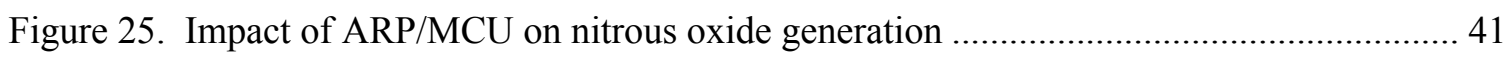

Figure 26. SME cycle hydrogen with and without ARP/MCU ............................................... 42 


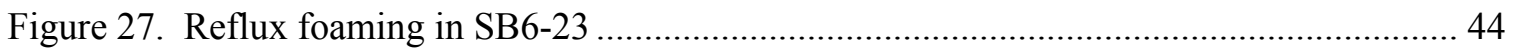

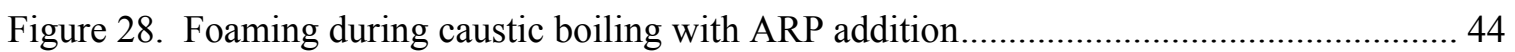

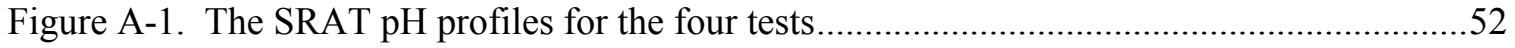

Figure A-2. The ammonia scrubber $\mathrm{pH}$ profiles for the final tests............................................53

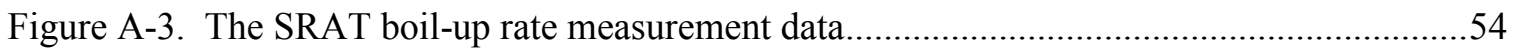

Figure A-4. SB6-21 SRAT product flow curves (duplicate) ........................................................54

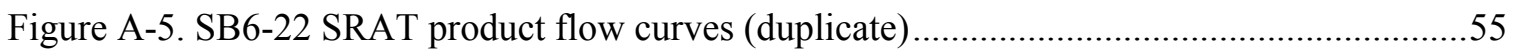

Figure A-6. SB6-23 SRAT product flow curves (duplicate) ........................................................55

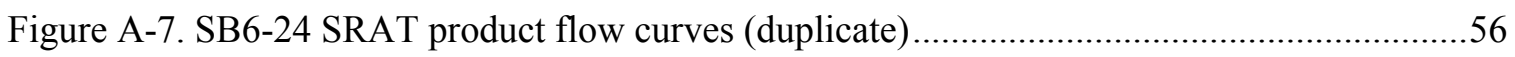

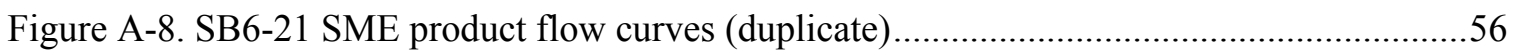

Figure A-9. SB6-22 SME product flow curves (duplicate) .....................................................57

Figure A-10. SB6-23 SME product flow curves (duplicate) ......................................................57

Figure A-11. SB6-24 SME product flow curves (duplicate) ........................................................58 


\section{LIST OF ABBREVIATIONS}

ACTL

$\mathrm{AD}$

CPC

CSTR

CV-AA

DWPF

E\&CPT

FAVC

GC

IC

ICP-AES

MWWT

PSAL

REDOX

SBn

SRAT

SRNL

SMECT

SME

TT\&QAP

TTR
Aiken County Technology Laboratory

Analytical Development

Chemical Process Cell

Continuous Stirred Tank Reactor

Cold Vapor Atomic Absorption

Defense Waste Processing Facility

Environmental and Chemical Process Technology

Formic Acid Vent Condenser (chilled water condenser)

Gas Chromatography

Ion Chromatography

Inductively Coupled Plasma-Atomic Emission Spectroscopy

Mercury Water Wash Tank

Process Science Analytical Laboratory

Reduction/Oxidation Potential

Sludge Batch n, e.g. SB2 is Sludge Batch 2, SB6 is Sludge Batch 6

Sludge Receipt and Adjustment Tank

Savannah River National Laboratory

Slurry Mix Evaporator Condensate Tank

Slurry Mix Evaporator

Task Technical and Quality Assurance Plan

Technical Task Request 


\subsection{Introduction}

The Defense Waste Processing Facility (DWPF) will transition from Sludge Batch 5 (SB5) processing to Sludge Batch 6 (SB6) processing in the latter half of fiscal year 2010. Phase IIITank 40 Chemical Process Cell (CPC) flowsheet simulations were conducted by the Savannah River National Laboratory (SRNL) using a non-radioactive simulant of the revised SB6/Tank 40 composition based on the November, 2009 composition projections for Tank 40 following the transfer from Tank 51. The Phase III test program was conducted to meet the objectives in the Technical Task Request (TTR). ${ }^{1}$ The testing followed the guidelines of a Task Technical and Quality Assurance Plan (TT\&QAP). ${ }^{2}$

The primary objective for the Phase III simulant testing was the determination of initial processing conditions for the DWPF transition from SB5 to SB6. A new SB6 simulant (SB6-G) was prepared for Phase III simulant testing. The composition was based on updated analyses of the qualification sample from Tank 51 plus revised projections for the wash endpoint and the Tank 51-to-40 transfer date. Updated values for mercury and noble metals from the qualification sample were also used compared to Phase II flowsheet testing. The updates included a reduced mercury value of $2.79 \mathrm{wt} \%$ in the total solids compared to $3.50 \mathrm{wt} \%$ in Phase II. SRAT cycles were performed at three different acid stoichiometries to evaluate the available acid addition window. The HM-rich waste in SB6 was relatively high in noble metal concentrations following sludge mass reduction, so hydrogen generation had been an issue in earlier SB6 simulations. SME cycles were conducted with two frit slurry additions and five canister decontamination water-frit additions at all three acid stoichiometries.

In addition to the stoichiometric acid window study, a fourth SRAT/SME simulation was performed to evaluate the incorporation of ARP and MCU streams into the current DWPF flowsheet. The acid addition was chosen to be comparable to the $120 \%$ acid stoichiometry case from the acid window study. Simulated ARP slurry was added during caustic boiling of the sludge simulant at a volumetric ratio of 7,000/6,000 relative to SB6 simulant. Solvent-free MCU solution was added during SRAT cycle boiling following acid addition and normal dewatering at a volume ratio of 8,000/6,000 relative to the SB6 simulant. The SME cycle simulated two fritformic slurry additions. This approach is believed to be sufficient to bound SME cycle hydrogen generation for the ARP/MCU test.

Off-gas data were obtained to evaluate hydrogen generation as well as $\mathrm{CO}_{2}$ and $\mathrm{N}_{2} \mathrm{O}$ generation. Profiles of slurry $\mathrm{pH}$ were obtained. Samples were taken following formic acid addition to check for nitrite ion concentration, metal dissolution, ammonium ion, and mercury. Slurry samples were taken periodically after acid addition to monitor the rate of mercury loss from the bulk slurry and to characterize the period of ammonium ion formation. Samples of each of the four SRAT and four SME products were used to measure the rheological properties of the eight product slurries. Reflux plus dewatering (or total time at boiling) in the SRAT cycle lasted about 35 hours and was done at the scaled DWPF design maximum boil-up rate of 5,000 $\mathrm{lbs} / \mathrm{hr}$ of steam. The 35 hour boiling period was calculated to be sufficient to meet the current DWPF SRAT cycle mercury specification of $0.45 \mathrm{wt} \% \mathrm{Hg}$ in the total solids at a stripping rate of $750 \mathrm{lb} \mathrm{steam} / \mathrm{lb} \mathrm{Hg}$.

SB6 contains a high concentration of mercury combined with high concentrations of Rh and Ru in the solids. A comparison of the trimmed Phase III SB6-G/Tank 40 blend simulant to the previous five qualification sludge batches (Tank 51 slurries) tested in the SRNL Shielded Cells is given in Table 1. The "Acid" row in Table 1 is $100 \%$ of the predicted acid stoichiometry by the 
current DWPF equation (Hsu/Marek equation), while actual acid row gives the actual quantity (or quantities) of acid used in the lab-scale SRAT cycle demonstration (in moles acid/L slurry). Additional explanation of nomenclature follows the table.

Table 1. Selected comparisons of SB6-G blend simulant to previous batches

\begin{tabular}{|l|c|c|c|c|c|c|}
\hline & SB2 & SB3 & $\begin{array}{c}\text { SB4 } \\
\text { (SC-3) }\end{array}$ & $\begin{array}{c}\text { SB5 } \\
\text { (SC-6) }\end{array}$ & $\begin{array}{c}\text { SB6 } \\
\text { (SC-9) }\end{array}$ & $\begin{array}{c}\text { SB6-G } \\
\text { (blend) }\end{array}$ \\
\hline Wt\% TS & 18.4 & 27.2 & 19.5 & 17.1 & 15.1 & 17.8 \\
\hline Base, M & 0.308 & 0.577 & 0.316 & 0.739 & 0.58 & 0.839 \\
\hline TIC, mg/kg & 866 & 1,260 & 2,510 & 1,280 & 913 & 1,050 \\
\hline Nitrite, $\mathrm{mg} / \mathrm{kg}$ & 7,529 & 25,300 & 20,500 & 8,660 & 10,000 & 13,950 \\
\hline $\mathrm{Mn}, \mathrm{wt} \%$ & 3.21 & 3.98 & 1.94 & 3.66 & 4.15 & 4.82 \\
\hline $\mathrm{Hg}, \mathrm{wt} \%$ & 0.195 & 0.0654 & 2.57 & 2.2 & 3.12 & 2.79 \\
\hline $\mathrm{Rh}, \mathrm{wt} \%$ & 0.00777 & 0.0071 & 0.0124 & 0.0250 & 0.0187 & 0.0177 \\
\hline $\mathrm{Ru}, \mathrm{wt} \%$ & 0.0332 & 0.0362 & 0.0529 & 0.110 & 0.0924 & 0.0846 \\
\hline Acid, mols/L & 0.751 & 1.63 & 1.30 & 1.32 & 1.12 & 1.49 \\
\hline Actual acid & 0.939 & 2.30 & 1.46 & 1.72 & 1.29 & $1.5-2.4$ \\
\hline
\end{tabular}

$\S$ - acid addition actually made after applying the stoichiometric factor in moles acid/L slurry; for SB6-G the range tested in this study is given.

SC-3, 6, and 9 are Shielded Cells nomenclature for their SRAT/SME simulations since SB3. The main reason for the SB6-G actual acid range being higher than the SB6 qualification test, SC-9, was that SB6-G was less washed and consequently contained more sodium hydroxide and nitrite. $\mathrm{Wt} \% \mathrm{TS}$ is weight percent total solids. Elemental wt \%'s are on a total solids basis. TIC is total inorganic carbon in $\mathrm{mg}$ carbon $/ \mathrm{kg}$ slurry. Base is the equivalent hydroxide molarity of the slurry titrated to $\mathrm{pH}$ 7. Nitrite is in $\mathrm{mg}$ nitrite/kg slurry. Actual acid in the SB6-G testing varied from $96-150 \%$ of the stoichiometric acid requirement determined using the new Koopman minimum acid equation. Stoichiometric factors were calculated using the Koopman and current DWPF stoichiometric acid equations. (The Koopman minimum acid equation predicted $6.5 \%$ more acid than the current DWPF acid equation at a 100\% factor.) Reports for the historical data are found in the Reference Section. 3, 4, 5,

\subsection{Summary of Experimental and Analytical Methods}

\subsection{Process and Sample Analytical Methods}

The automated data acquisition system developed for the 4-L SRAT rigs was used to collect electronic data on a computer. Collected data included SRAT slurry temperature, bath temperatures for the cooling water to the SRAT condenser and Formic Acid Vent Condenser (FAVC), slurry $\mathrm{pH}$, SRAT mixer speed and torque, air and helium purge flows (helium is used as an internal standard and is set to $0.5 \%$ of the nominal SRAT air purge flow). Cumulative acid addition volume data were collected from the automated dispensers using an algorithm that matches the indicated total on the dispenser. Some $\mathrm{pH}$ data were obtained for the nitric acid reservoir that supplied the reflux flow to the ammonia scrubbers. Raw GC chromatographic data were acquired on separate computers dedicated to each instrument.

The chilled off-gas leaving the FAVC was passed through a Nafion dryer in counter-current flow with a dried air stream to reduce the moisture content at the GC inlet. Agilent 3000A micro GC's were used on all four runs. The GC's were baked out before and between runs. Column-A can 
collect data related to $\mathrm{He}, \mathrm{H}_{2}, \mathrm{O}_{2}, \mathrm{~N}_{2}, \mathrm{NO}$, and $\mathrm{CO}$, while column-B can collect data related to $\mathrm{CO}_{2}, \mathrm{~N}_{2} \mathrm{O}$, and water. GC's were calibrated with a standard calibration gas containing 0.499 vol $\% \mathrm{He}, 1.000$ vol $\% \mathrm{H}_{2}, 20.00$ vol $\% \mathrm{O}_{2}, 51.511$ vol $\% \mathrm{~N}_{2}, 24.49$ vol $\% \mathrm{CO}_{2}$ and $2.50 \mathrm{vol} \% \mathrm{~N}_{2} \mathrm{O}$. The calibration was verified prior to starting the SRAT cycle and after completing the SME cycle. Room air was used to give a two point calibration for $\mathrm{N}_{2}$. No evidence for $\mathrm{CO}$ generation was obtained while examining the region of the chromatogram where it would elute.

Process samples were analyzed by various methods. Slurry and supernate elemental compositions were determined by inductively coupled plasma-atomic emission spectroscopy (ICP-AES) at the Process Science Analytical Laboratory (PSAL). Slurry samples were calcined at $1100^{\circ} \mathrm{C}$. The main advantage of this approach is to permit easier comparisons between SRAT product elements and sludge elements. Noble metals and mercury are trimmed uniquely to each SRAT, and their concentrations are known more accurately from material balance considerations than they could be from ICP-AES analyses.

Soluble slurry anions were determined by ion chromatography (IC) on 100-fold weighted dilutions of slurry with water followed by filtration to remove the remaining insoluble solids. SRAT cycle, SME cycle, and SRAT product slurry samples were either submitted to Analytical Development (AD) for mercury analysis by cold vapor atomic absorption (CV-Hg) or to PSAL for analysis by ICP-AES. Selected dewatering condensate samples were checked for dissolved mercury by ICP-AES. An SB6-G simulant sample and a SRAT receipt sample following ARP addition in SB6-24 were submitted to AD for total inorganic carbon analysis of both the starting slurry and the supernate. These two slurries were analyzed by PSAL for slurry and supernate density using the Anton-Parr instrument. Starting sludges were titrated to $\mathrm{pH} 7$ using the PSAL auto-titrator to determine the base equivalents for input into the stoichiometric acid equation. Samples of SRAT cycle slurries, SRAT and SME product slurries, and SRAT and SME cycle condensates were analyzed by AD using cation chromatography for ammonium ion.

\subsection{Simulant Preparation and Characterization}

The SB6-G simulant was prepared using the current continuous stirred tank reactor (CSTR) precipitation method. $^{7}$ This method involved the following processing steps:

- A slurry of precipitated $\mathrm{MnO}_{2}$ was prepared.

- An acidic metal nitrate solution was prepared.

- The two were combined and fed to the CSTR along with a $50 \mathrm{wt} \%$ sodium hydroxide solution to produce a caustic slurry of hydrous metal oxide and hydroxide solids in a sodium nitrate solution at a $\mathrm{pH}$ of about 9.5 .

- The slurry was contacted with sodium carbonate to permit conversion of some of the hydroxides to carbonates.

- The slurry was decanted and washed until the nitrate concentration was below the target supernate nitrate concentration.

- The slurry was concentrated to a point consistent with the targeted total solids value for the final slurry.

- Silica, $\mathrm{TiO}_{2}$, and sodium salts were added to complete the preparation.

Table 2 presents the average elemental results of duplicate analyses of two slurry samples from the SB6-G simulant calcined at $1100^{\circ} \mathrm{C}$. Results for the SB6-24 SRAT receipt sample are also given. The SB6-24 SRAT receipt sample includes the contribution from the ARP slurry, the most significant of which is from the MST. Results were generally as expected. 
Table 2. Elemental composition of simulants calcined at $1100^{\circ} \mathrm{C}, \mathrm{wt} \%$

\begin{tabular}{|c|c|c|}
\hline Element & SB6-G & $\begin{array}{c}\text { SB6-24 SRAT } \\
\text { receipt with ARP }\end{array}$ \\
\hline $\mathrm{Al}$ & 13.0 & 11.8 \\
\hline $\mathrm{Ba}$ & 0.13 & 0.12 \\
\hline $\mathrm{Ca}$ & 0.63 & 0.71 \\
\hline $\mathrm{Ce}$ & 0.20 & 0.16 \\
\hline $\mathrm{Cr}$ & 0.17 & 0.14 \\
\hline $\mathrm{Cu}$ & 0.10 & 0.09 \\
\hline $\mathrm{Fe}$ & 20.6 & 17.4 \\
\hline $\mathrm{K}$ & 0.08 & 0.07 \\
\hline $\mathrm{La}$ & 0.10 & 0.08 \\
\hline $\mathrm{Mg}$ & 0.50 & 0.55 \\
\hline $\mathrm{Mn}$ & 6.2 & 5.2 \\
\hline $\mathrm{Na}$ & 17.6 & 18.6 \\
\hline $\mathrm{Ni}$ & 2.8 & 2.3 \\
\hline $\mathrm{P}$ & $<0.1$ & $<0.1$ \\
\hline $\mathrm{Pb}$ & $<0.01$ & 0.02 \\
\hline $\mathrm{S}$ & 0.39 & 0.45 \\
\hline $\mathrm{Si}$ & 1.26 & 1.17 \\
\hline $\mathrm{Ti}$ & 0.03 & 2.97 \\
\hline $\mathrm{Zn}$ & 0.09 & 0.09 \\
\hline $\mathrm{Zr}$ & 0.26 & 0.25 \\
\hline
\end{tabular}

Table 3 presents results for total, insoluble, soluble and calcined wt $\%$ solids, slurry and supernate density, slurry base equivalent molarity, slurry and supernate total inorganic carbon (TIC), and the slurry anion results from IC.

Table 3. Other simulant analyses

\begin{tabular}{|l|c|c|}
\hline & SB6-G & $\begin{array}{c}\text { SB6-24 SRAT } \\
\text { receipt }\end{array}$ \\
\hline Total solids, $\mathrm{wt} \%$ & 17.7 & 18.4 \\
\hline Insoluble solids, wt\% & 10.9 & 10.3 \\
\hline Soluble solids, $\mathrm{wt} \%$ & 6.9 & 8.1 \\
\hline Calcined solids, wt\% & 13.9 & 13.4 \\
\hline Slurry density, g/mL & 1.149 & 1.152 \\
\hline Supernate density, g/mL & 1.062 & 1.067 \\
\hline Slurry base equiv., mol/kg & 0.839 & 0.657 \\
\hline Nitrite, $\mathrm{mg} / \mathrm{kg}$ & 13,950 & 13,650 \\
\hline Nitrate, $\mathrm{mg} / \mathrm{kg}$ & 8,030 & 14,200 \\
\hline Sulfate, $\mathrm{mg} / \mathrm{kg}$ & 1820 & 2390 \\
\hline Oxalate, $\mathrm{mg} / \mathrm{kg}$ & 550 & 3800 \\
\hline Chloride, $\mathrm{mg} / \mathrm{kg}$ & 244 & 408 \\
\hline Slurry TIC, $\mathrm{mg} / \mathrm{kg}$ slurry & 1047 & 1129 \\
\hline Supernate $\mathrm{TIC}, \mathrm{mg} / \mathrm{L}$ supernate & 916 & 1180 \\
\hline
\end{tabular}


The SB6-G tests had 3,200 g of starting sludge (before trim chemicals and rinse water) except for the ARP/MCU test which started with 2,570 $\mathrm{g}$ of SB6-G simulant. The quantity of ARP slurry added to the SB6-G simulant had a solids mass equivalent to that in $630 \mathrm{~g}$ of SB6-G. Therefore, the ARP/MCU test was comparable in size and solids mass to the other three tests following ARP addition and dewatering.

Rhodium was trimmed as a solution of $\mathrm{Rh}\left(\mathrm{NO}_{3}\right)_{3}$ containing $4.93 \mathrm{wt} \%$ rhodium. Ruthenium was added as the dry trivalent chloride salt at a purity of $41.73 \mathrm{wt} \% \mathrm{Ru}$. Palladium was trimmed as a solution of $\mathrm{Pd}\left(\mathrm{NO}_{3}\right)_{2}$ containing $15.27 \mathrm{wt} \%$ palladium. Silver was added as the dry nitrate salt $\mathrm{AgNO}_{3}$. Mercury was trimmed as dry HgO. Targets for the SB6-G testing are given in Table 4 along with the reported values for the SC-6 (SB-5) and SC-9 (SB-6) SRAT receipt sample from the Shielded Cells qualification runs for comparison., ${ }^{3,8}$ SB6-24 was trimmed for mercury and noble metals assuming that the ARP solids were 50\% MST and 50\% SB6-G entrained sludge. This resulted in concentrations in the SB6-24 total solids that were $89.1 \%$ those of SB6-G.

Table 4. Noble metal and mercury targets

\begin{tabular}{|l|c|c|c|c|}
\hline & $\begin{array}{c}\text { SC-6 (Tank } \\
\text { 51/SB5) }\end{array}$ & $\begin{array}{c}\text { SC-9 (Tank } \\
\text { 51/SB6) }\end{array}$ & $\begin{array}{c}\text { SB6-G } \\
\text { (Tank 40) }\end{array}$ & $\begin{array}{c}\text { SB6-24 } \\
\text { (with ARP) }\end{array}$ \\
\hline $\mathrm{Rh}, \mathrm{wt} \%$ & 0.025 & 0.0187 & 0.0177 & 0.0158 \\
\hline $\mathrm{Ru}, \mathrm{wt} \%$ & 0.110 & 0.0924 & 0.0845 & 0.0753 \\
\hline $\mathrm{Hg}, \mathrm{wt} \%$ & 2.22 & 3.12 & 2.79 & 2.49 \\
\hline $\mathrm{Pd}, \mathrm{wt} \%$ & 0.0040 & 0.0030 & 0.0028 & 0.0025 \\
\hline $\mathrm{Ag}, \mathrm{wt} \%$ & 0.0135 & 0.0138 & 0.0142 & 0.0127 \\
\hline
\end{tabular}

SB5 in Tank 40 as processed (blended with the SB4 heel) actually had lower noble metal concentrations than the SC-6 qualification sample from Tank 51. SB6-G behavior was expected to be very similar to that of the SC-6 and 9 radioactive waste slurries.

\section{3 $\underline{\text { Chemical Process Cell Simulation Details }}$}

The trimmed SRAT receipt volume was about 2.9 L. The 4-L lab-scale SRAT equipment was used for these tests. A photo of the modified 4-L rig with the ammonia scrubber is shown in Figure 1. 


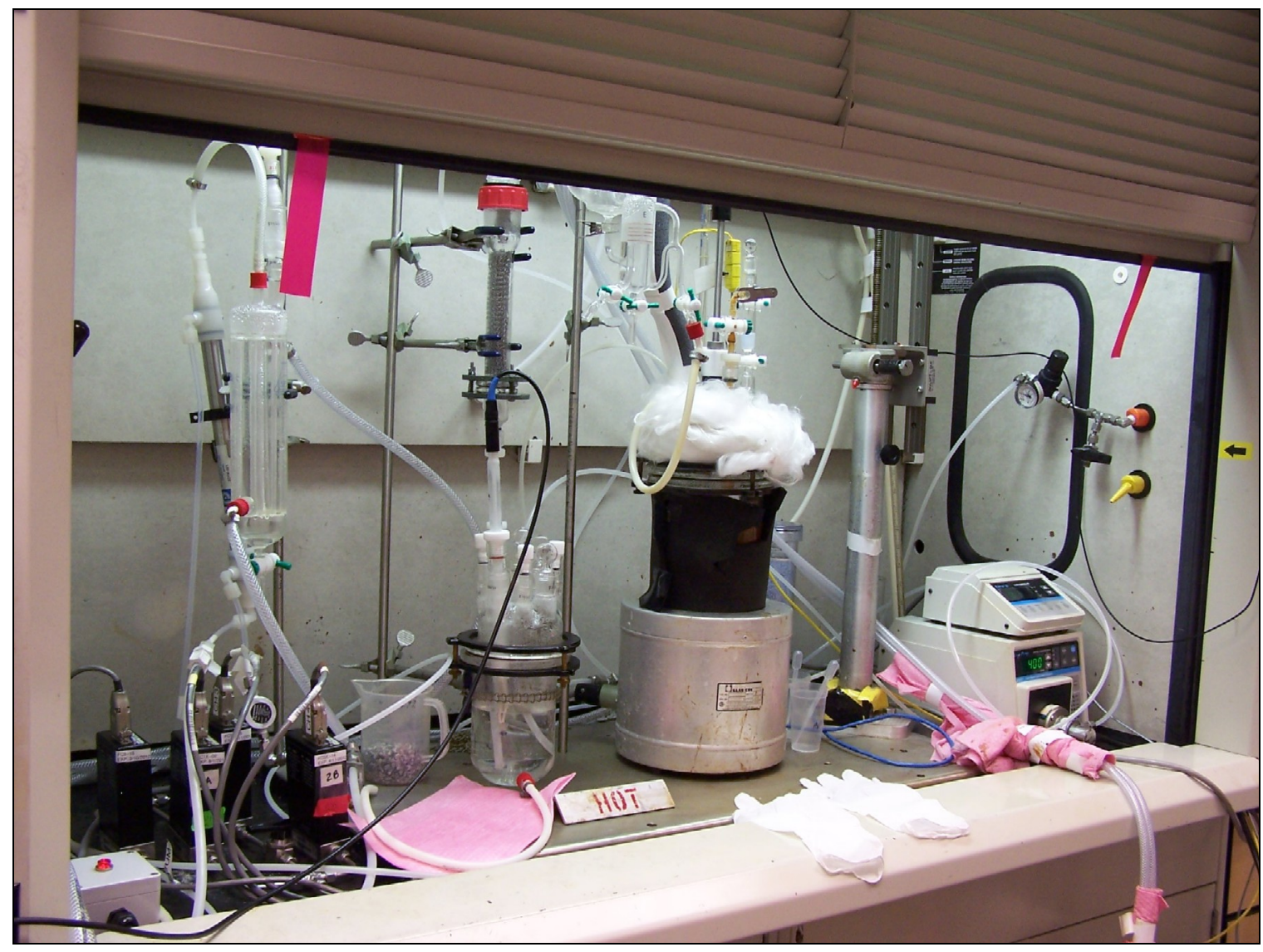

Figure 1. Lab-scale SRAT with ammonia scrubber

The reservoir below the ammonia scrubber was charged with a solution of $749 \mathrm{~g}$ of de-ionized water and $1 \mathrm{~g}$ of $50 \mathrm{wt} \%$ nitric acid. This solution was recirculated by a MasterFlex driven Micropump gear pump at about $300 \mathrm{~mL}$ per minute to a spray nozzle at the top of the packed section. The addition of the scrubber to the off-gas system added to back-pressure on the SRAT vessel and led to an increase in fugitive emissions at the various fittings (increased the uncontrolled loss of water vapor from the system).

Initial acid calculations were based on the new Koopman minimum acid requirement equation. ${ }^{9}$

$$
\frac{\text { moles acid }}{\text { L slurry }}=\text { base equivalents }+H g+\text { soluble } T I C+1.5 *(C a+M g)+1.0 * \text { nitrite }+1.5 * M n
$$

Three different stoichiometric factors were used in the three non-ARP/MCU acid calculations, $96 \%, 113 \%$, and $150 \%$. The ARP/MCU run was matched to the intermediate, or $113 \%$, case. Acid calculations were also performed using the current DWPF algorithm for comparison: ${ }^{10}$

$$
\frac{\text { moles acid }}{L \text { slurry }}=\text { base equivalents }+2 * \text { total TIC }+0.75 * \text { nitrite }+1.2 * \mathrm{Mn}+\mathrm{Hg}
$$

The results of these two calculations for the Phase II (SB6-D) and Phase III (SB6-G) simulants are summarized in Table 5. The table also includes the actual acid additions made based on 
$150 \%$ of the Koopman minimum acid equation (maximum acid) and the equivalent DWPF stoichiometric factors (percent) to go from the DWPF acid equation values to the actual acid additions.

Table 5. Stoichiometric acid calculation results, moles acid/L slurry

\begin{tabular}{|l|c|c|c|c|}
\hline & $\begin{array}{c}\text { DWPF Eqn. } \\
\text { moles/L }\end{array}$ & $\begin{array}{c}\text { Koopman Min. } \\
\text { moles/L }\end{array}$ & $\begin{array}{c}\text { Actual addition at } \\
\mathbf{1 5 0 \%} \text {, moles/L }\end{array}$ & $\begin{array}{c}\text { Equivalent } \\
\text { DWPF factor }\end{array}$ \\
\hline Phase II & 1.43 & 1.46 & 2.20 & $153 \%$ \\
\hline Phase III & 1.49 & 1.59 & 2.38 & $159 \%$ \\
\hline
\end{tabular}

Total acid was partitioned between formic and nitric acids using the latest RedOx equation. ${ }^{11}$ Assumptions of $20-35 \%$ formate loss and of $10 \%$ to $-10 \%$ nitrite-to-nitrate conversions were also made to enable this calculation to be performed based on prior experience with the SB6-D and SB6-E simulants. These assumptions gave the fraction of the total acid moles that was formic acid in the range of $0.86-0.91$.

Scaled design basis DWPF SRAT/SME processing conditions were generally used. The SRAT and SME cycles, however, did not have a heel from a prior batch.

- The SRAT air purge scaled to $230 \mathrm{scfm}$ in DWPF.

- A 200 ppm antifoam addition was made prior to nitric acid addition.

- A 100 ppm antifoam addition was made prior to formic acid addition.

- Nitric and formic acid addition were made at $93^{\circ} \mathrm{C}$.

- Acids were added at two gallons per minute scaled from 6,000 gallons to $2.5 \mathrm{~L}$.

- A $500 \mathrm{ppm}$ antifoam addition was made prior to going to boiling following acid addition.

- Boiling assumed a condensate production rate of 5,000 lbs/hr at DWPF scale.

- SRAT dewatering took about 3.2-3.7 hours to produce a $25 \mathrm{wt} \%$ total solids slurry.

- Reflux followed dewatering. The end of the 32-hour reflux period defined the end of the SRAT cycle.

- The SME air purge scaled to $74 \mathrm{scfm}$ in DWPF.

- A 100 ppm antifoam addition was made at the start of the SME cycle.

- Five water additions equivalent to 1000 gallons each were made to simulate canister decontamination water additions and dewaterings.

- Two frit-water-formic acid additions were made targeting 34\% waste loading.

- The SME was dewatered following each frit slurry addition.

- The final SME solids target was $48 \mathrm{wt} \%$.

Fifteen to twenty samples were taken during the SRAT cycle to monitor major reactions. Major species were checked immediately after acid addition. Samples were pulled during boiling to monitor suspended and dissolved mercury in the SRAT slurry. These samples were pulled directly into digestion vials to eliminate potential segregation of mercury during subsampling/aliquoting steps. The SRAT and SME product slurries were sampled similarly while the vessel contents were still mixing once they had cooled to $90^{\circ} \mathrm{C}$.

Additional SRAT product samples were taken for compositional and solids analyses after the product had cooled further. The MWWT and FAVC were drained and the condensates weighed after both the SRAT and SME cycle. The MWWT was temporarily removed from the apparatus after the SRAT cycle, and as much free mercury as possible was collected for weighing. The MWWT was re-installed for the SME but not refilled. The SRAT cycle FAVC condensate was 
submitted for ammonium ion analysis as a check on the performance of the new ammonia scrubbers. Selected SME dewatering condensate samples were also submitted for ammonium ion analysis.

\subsection{Results and Discussion}

The sections below summarize the results for off-gas analysis, sample analyses, determination of formate lost and nitrite converted to nitrate, etc. Two issues had emerged in the course of earlier SB6 testing, however, that are noteworthy and will be discussed in separate sections. The two issues were mercury removal and ammonium ion generation. Complete SRAT and SME elemental analyses, simulation $\mathrm{pH}$ profiles, boil-up rate profiles, and product sample rheological data were placed in Appendix A.

\subsection{Mercury Removal in Phase III Testing}

The starting SB6-G sludge solids were trimmed with $\mathrm{Hg}$ prior to SRAT simulations. An assumed stripping efficiency of $1 \mathrm{~g} \mathrm{Hg} / 750 \mathrm{~g}$ water boiled yielded an estimated stripping time of just over 35 hours at the lab-scale boil-up rate equivalent to 5,000 lb/hr in DWPF. The boiling time was split approximately into 3 hours of dewatering plus 32 hours of reflux. The actual time from the end of formic acid addition to the start of reflux varied from 4.1-4.4 hours. This time includes the time to bring the SRAT to boiling. All four tests had 32 hours of reflux time. The boil-up rate was checked periodically during reflux and was within $\pm 10 \%$ of the target.

Elemental mercury collected in the center drain tee of the lab-scale MWWT. The appearance of the mercury varied from test to test, see Figure 2, generally appearing more ragged as acid stoichiometry increased. A dark impurity was present in the high acid run. It was visible as dark spots mixed in with the mercury (arrow hi-lites).

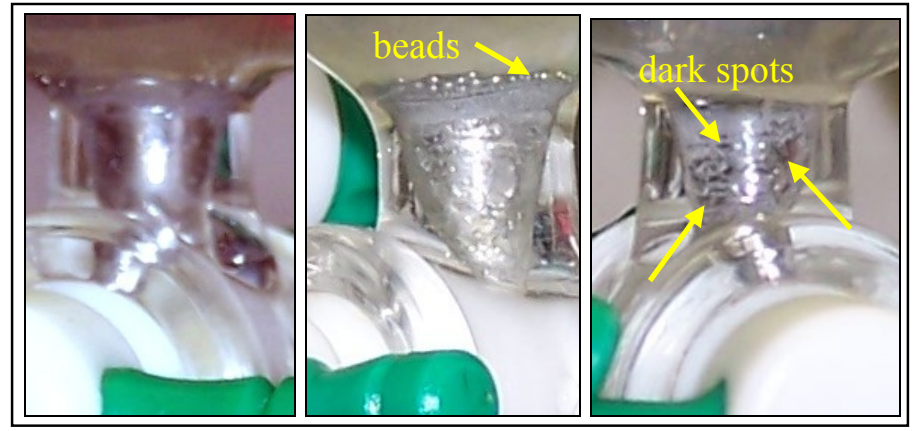

Figure 2. SB6-21 Hg (left), SB6-23 (middle), and SB6-22 Hg (right)

The individual frames are enlarged several-fold (relative to $8 \frac{1}{2}$ by 11 -inch paper) to show details. The mercury appeared to form a single homogeneous liquid phase in the low acid run, SB6-21, on the left. Individual small beads showed no tendency to coalesce together in the other three runs. After the SRAT cycle was completed, the elemental mercury was collected in a $30-\mathrm{mL}$ sample bottle for weighing.

Several large beads formed along with dozens of smaller beads that would not coalesce into the large beads when the SB6-24 (ARP/MCU) run MWWT mercury was isolated from the aqueous phase, Figure 3. 


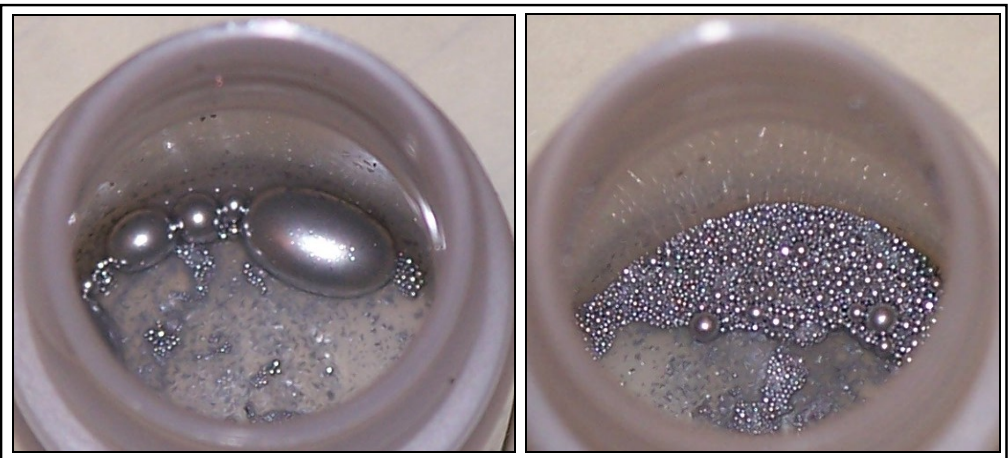

Figure 3. Mercury collected from the MWWT of SB6-24 (ARP/MCU)

The largest beads visible in the left-hand image were free to roll around inside the bottle, while the smaller beads were stuck to the bottom. The three larger beads would roll right over the top of the smaller beads without incorporating them.

Scale-like deposits of mercury formed on the walls of some of the off-gas system glassware. A stretched color image, Figure 4, of the MWWT after the SME cycle of SB6-23 (120\%) was prepared to enhance details of the deposits (marked by arrows) on the vessel wall.

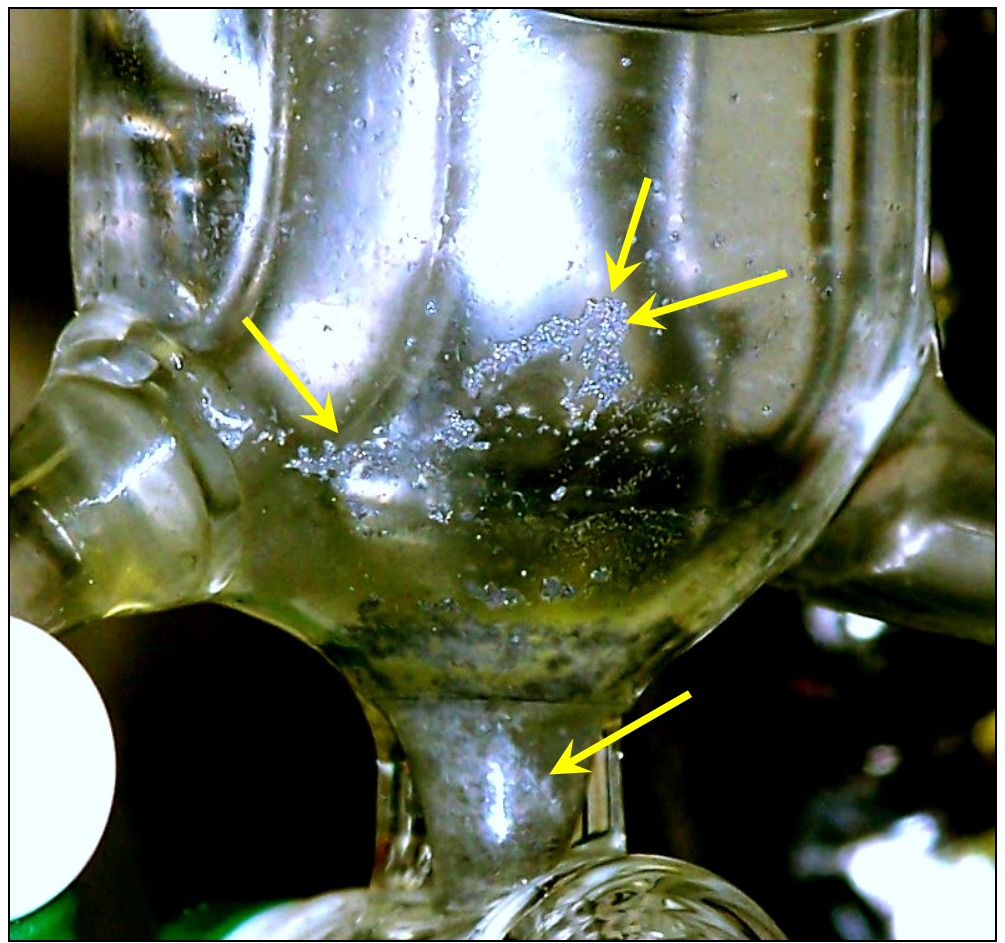

Figure 4. SB6-23 MWWT mercury-rich deposits

Deposits were also seen in the SRAT condenser and the small diameter glass tube that condensate from the SRAT condenser uses to drain into the MWWT. Deposits were generally a dull gray color (not the light blue-gray in Figure 4) suggestive of mercury that has lost its shine. Deposits were not limited to SB6-23. 
Mixing speeds in the SRAT were increased relative to earlier SB6 simulations in an attempt to keep the mercury dispersed better and longer into the cycle. Profiles of SRAT slurry mercury concentration versus time after acid addition were developed for the four SRAT/SME simulations. These are given in Figure 5. Stoichiometries for the runs are by the Koopman minimum acid equation (corresponding to 102, 120 and $159 \%$ by the DWPF equation). The points at 46 hours are from the samples following canister decon dewaterings, and the samples at 54 hours are from the SME product.

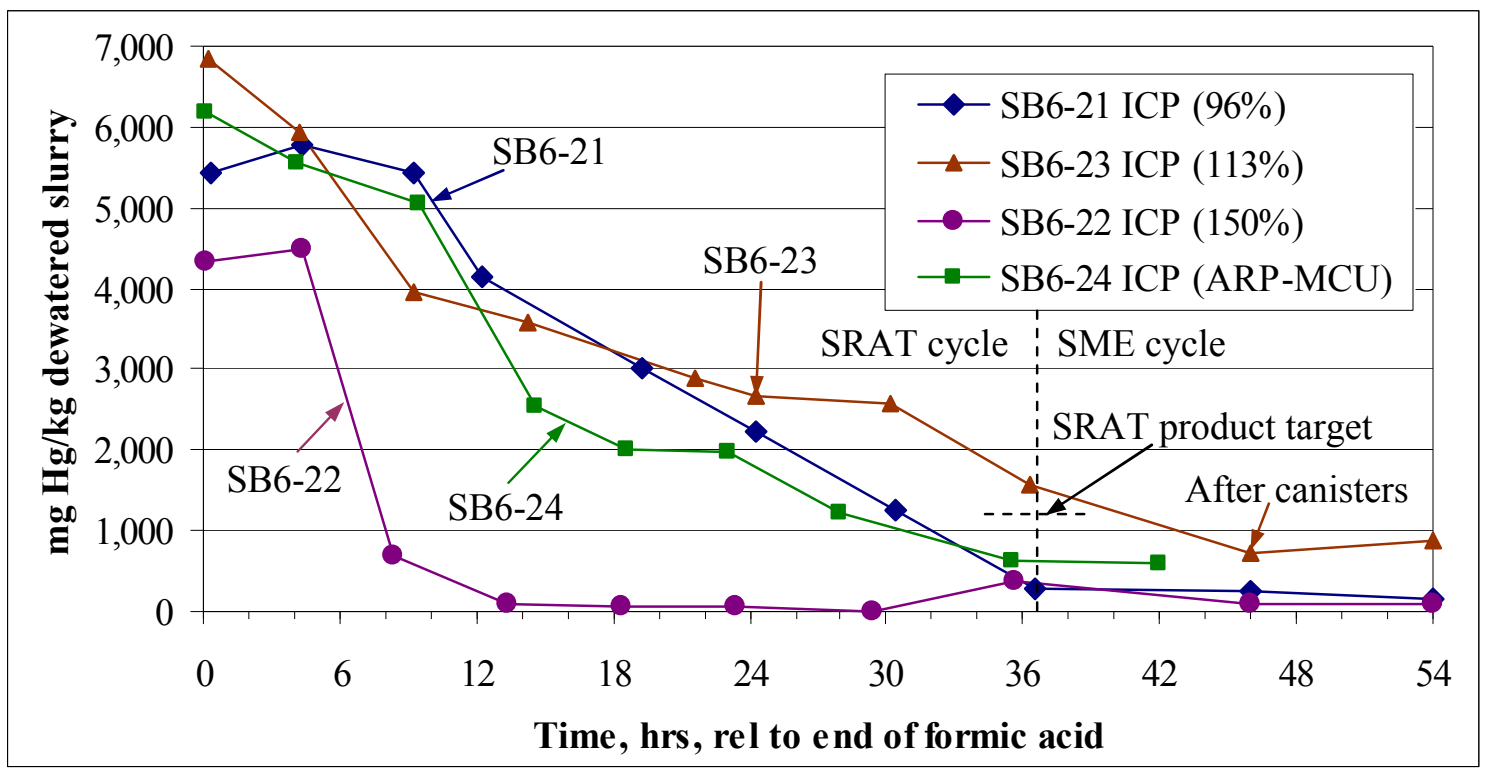

Figure 5. Slurry mercury concentration as a function of time

SB6-21, 23, and 24 followed generally similar trends, although SB6-23 seemed to fall behind the other two about 25 hours after formic acid addition. SB6-21, 22, and 24 SRAT product samples were in the $0.11-0.21 \mathrm{wt} \% \mathrm{Hg}$ range on a total solids basis, while SB6-23 was at $0.59 \mathrm{wt} \% \mathrm{Hg}$. The analytical results are likely to be lower bounds on the actual mercury remaining in the SRAT.

A SME slurry sample was obtained following the five canister dewaterings during SB6-21 to 23. The mercury results for SB6-21 and 22 were consistent with the SRAT product results, but the result for SB6-23 indicated a further factor of two reduction in mercury concentration relative to the SRAT product concentration, i.e. this run was considerably closer in $\mathrm{Hg}$ concentration to SB6-21 and 22 mid-way through the SME cycle than it was at the end of the SRAT cycle.

SB6-22, the high acid run, had a very rapid drop in slurry mercury concentration shortly after reflux was initiated. Some of this mercury was found after the run was over. Mercury-rich deposits with a clay-like consistency were found on the impeller blades in SB6-22, Figure 6 (enclosed in ovals). 


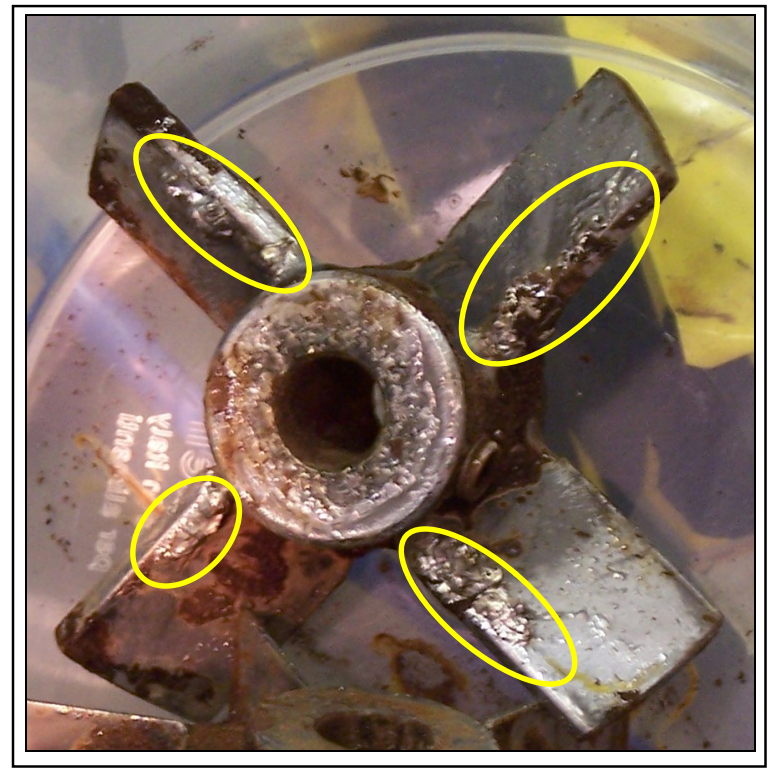

Figure 6. SB6-22 pitched-blade turbine with deposits

The deposits were somewhat reflective, but not the highly mirrored surface characteristic of pure elemental mercury. The deposits were also not remotely droplet shaped, or even rounded. Instead they were clay-like, having a lot of surface texture, and were spread out along the edges of the blades. Immersing the impeller in about $9 \mathrm{M}$ nitric acid solution caused $5.26 \mathrm{~g}$ of material to come off of the blades (relative to about $16 \mathrm{~g}$ of elemental $\mathrm{Hg}$ added to the run). The volume of material would scale up to about 1.5-2 gallons at DWPF-scale.

Additional mercury equivalent to twice the mass in the impeller deposits was unaccounted for in SB6-22. It is possible that additional mercury-rich material had been on the lower Rushton impeller at the end of the SME cycle (it was much cleaner than the upper pitched blade turbine when both were inspected later). Some deposits may have been inadvertently scraped off by the technicians as they were removing the impellers and shaft from the vessel as part of the post-run cleaning process.

The mercury-rich deposits that dissolved off of the SB6-22 impellers were analyzed by ICP-AES to get an elemental analysis. The results are given in Table 6 . Unexpectedly high values (relative to SB6-G simulant) are bolded for emphasis.

Table 6. Elements dissolved from agitator impeller deposits, $\mathrm{mg} / \mathrm{L}$ acid

\begin{tabular}{|c|c|c|c|c|c|c|c|}
\hline $\mathrm{Al}$ & $\mathrm{Ba}$ & $\mathrm{Ca}$ & $\mathrm{Ce}$ & $\mathrm{Cr}$ & $\mathrm{Cu}$ & $\mathrm{Fe}$ & $\mathrm{Hg}$ \\
\hline 140 & 0.65 & 8.95 & 1.5 & 1.68 & $\mathbf{3 5 9}$ & 149 & $\mathbf{6 9 8 0}$ \\
\hline \hline $\mathrm{K}$ & $\mathrm{La}$ & $\mathrm{Mg}$ & $\mathrm{Mn}$ & $\mathrm{Na}$ & $\mathrm{Ni}$ & $\mathrm{P}$ & $\mathrm{Pb}$ \\
\hline 1.4 & 0.8 & 5.5 & 56 & 95 & 23 & $<0.1$ & 4.7 \\
\hline \hline $\mathrm{Pd}$ & $\mathrm{Rh}$ & $\mathrm{Ru}$ & $\mathrm{S}$ & $\mathrm{Si}$ & $\mathrm{Ti}$ & $\mathrm{Zn}$ & $\mathrm{Zr}$ \\
\hline $\mathbf{1 9}$ & $\mathbf{6 5}$ & $\mathbf{1 1}$ & 2.8 & 15 & $<0.01$ & 1.8 & 1.9 \\
\hline
\end{tabular}

The deposits were also essentially free of frit (no B, no increased level of Si or Li, etc.). Mercury made up $88 \%$ of the cation content, and it was assumed that roughly $80 \%$ of the solids mass of the deposits was elemental $\mathrm{Hg}$ for use in the mercury material balances (based on assuming that 
the majority of the other solids were present as sludge compounds). The mercury in the impeller deposits corresponded to about a quarter of the starting mercury mass.

Further analysis of the sample results was made under the assumption that the deposits were essentially a mixture of a mercury-rich amalgam and SRAT product insoluble solids combined with a small amount of supernate (since the solids were clearly still moist at the start of the preanalysis acid dissolution). Subtracting out SB6-G simulant-based insoluble and supernate solids led to the following relative breakdown of elements in the amalgam: $93 \% \mathrm{Hg}, 5 \% \mathrm{Cu}, 1 \% \mathrm{Rh}$, $0.5 \% \mathrm{Ru}, 0.25 \% \mathrm{Pd}$, and $0.07 \% \mathrm{Ca}$. $\mathrm{Cu}, \mathrm{Rh}$, and $\mathrm{Pd}$ were enriched in the amalgam by over a factor of 200 relative to the respective sludge solid concentrations, while $\mathrm{Ru}$ was enriched by about a factor of 30 and $\mathrm{Ca}$ by a factor of 6 . Based on the mass of solids on the impeller and the composition, it was possible to calculate that about $50 \%$ of the $\mathrm{Rh}$ and $\mathrm{Cu}$ in the trimmed starting sludge had been incorporated into the deposit. Potentially $100 \%$ of the initial Pd and $5 \%$ of the initial $\mathrm{Ru}$ were also in the deposit. The fact that $95 \%$ of the $\mathrm{Ru}$ was still free may partially explain the ability of the system to sustain hydrogen generation.

Mercury-noble metal amalgams were made 25 years ago during some scoping tests in the lab related to using mercury to recover the noble metals in the sludge waste. The expected form of the noble metals in the mercury amalgam is as metal atoms. It is postulated that the copper in the amalgam may also be elemental. Elemental $\mathrm{Hg}-\mathrm{Cu}$ redox reactions are well known. One explanation for the formation of elemental copper is that dissolved $\mathrm{Cu}$ (II) ions were chemically reduced to $\mathrm{Cu}(\mathrm{I})$ ions. Pairs of $\mathrm{Cu}(\mathrm{I})$ ions subsequently reacted together to form a $\mathrm{Cu}(\mathrm{II})$ ion and elemental copper (perhaps at the surface of the deposit). This amalgam could be partially responsible for catalyzing the ammonium ion formation reaction sequence (especially since it has incorporated a lot of the available noble metals into it).

Two SME product slurry samples were obtained from each run and digested and analyzed similarly to the SRAT samples. The measured mass of the SME product slurry and the calculated mass of the SRAT product slurry after sampling were within 5\% for each of the four tests. The SME product mass essentially consisted of $25 \%$ frit and $75 \%$ concentrated SRAT product. SME and SRAT product results are compared in Table 7.

Table 7. Comparison of SRAT and SME product Hg results

\begin{tabular}{|l|l|c|c|c|c|}
\hline Run & $\begin{array}{l}\text { Acid by } \\
\text { DWPF eqn. }\end{array}$ & $\begin{array}{c}\text { SRAT } \\
\text { mg Hg/kg }\end{array}$ & $\begin{array}{c}\text { SRAT, wt\% } \\
\text { Hg in TS }\end{array}$ & $\begin{array}{c}\text { SME } \\
\text { mg Hg/kg }\end{array}$ & $\begin{array}{c}\text { SME, wt\% } \\
\text { Hg in TS }\end{array}$ \\
\hline SB6-21 & $102 \%$ & 286 & 0.11 & 165 & 0.03 \\
\hline SB6-23 & $120 \%$ & 1,580 & 0.59 & 884 & 0.17 \\
\hline SB6-22 & $159 \%$ & 367 & 0.15 & 89 & 0.02 \\
\hline SB6-24 & ARP (119\%) & 614 & 0.21 & 594 & 0.11 \\
\hline
\end{tabular}

The slurry concentration data generally indicate further successful removal of $\mathrm{Hg}$ from the bulk slurry during the SME cycle. Little change was seen in the APR/MCU run. The ARP/MCU run, however, had roughly one-third the SME cycle boiling time of the others, since it did not have the five canister dewaterings. The canister decon additions were eliminated from SB6-24 to offset the caustic boiling time associated with ARP addition so that the test ended close to the same time as SB6-23. The results for $\mathrm{wt}^{\%} \mathrm{Hg}$ in the SRAT product, given in the table, are based on the sample analyses. Significant mercury was unaccounted for at higher acid stoichiometries. Therefore, the SB6-22 sample result of $0.15 \%$ could potentially be much larger than $0.6 \mathrm{wt} \%$ if the missing mercury was still in the SRAT vessel. 
Portions of each SME product were poured into pans and allowed to dry for visual examinations for the presence of unusual mercury content. Small beads of mercury were found embedded in some of the dried SME product, but no really unusual concentrations of mercury were seen. For example, SB6-23, which had considerable retained mercury according to analysis looked like Figure 7.

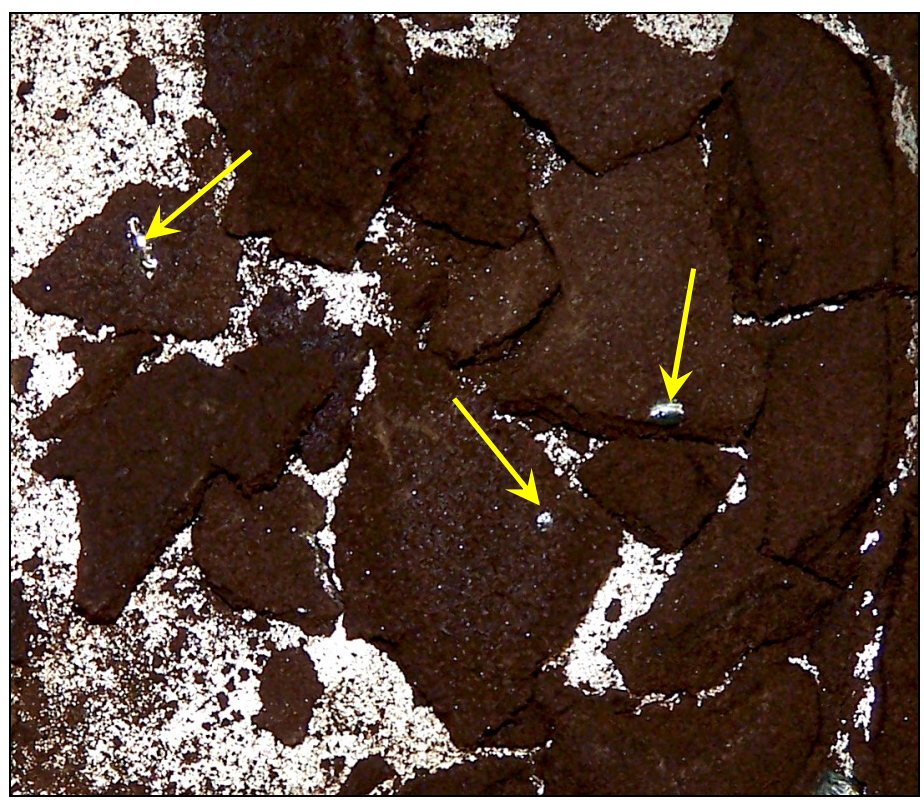

Figure 7. A dried portion of SB6-23 SME product slurry

The SB6-23 SME product did have some patches of mercury on some of the dried solids in addition to the finely dispersed small droplets that are nearly invisible at the scale of Figure 7. One similar patch and one small bead were found in the SB6-24 dried SME product along with some of the finely dispersed small droplets. It was impossible to quantify any differences that might have existed between the four SME products. Here is a photo from SB6-21 which had the best mercury material balance closure, Figure 8 . 


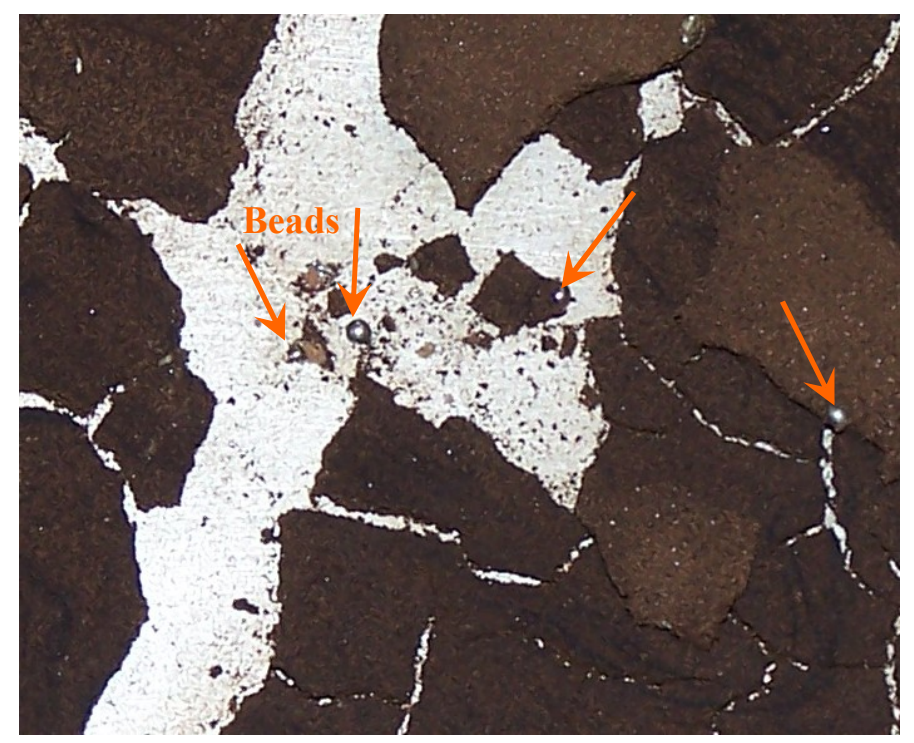

Figure 8. A dried portion of SB6-21 SME product slurry

Two small beads of mercury and a small patch are visible in the drying pan that could easily include more mercury than was found visually in SB6-23.

Mass balances on mercury were prepared as part of the SRAT Hg removal analysis. Since SME cycles were performed during these four tests, the material balances were performed across the combined SRAT and SME cycles. Four terms were included in the mercury balance: feed mercury, slurry mercury, mercury in the condensates from dewatering, and elemental mercury. The $17.67 \mathrm{~g}$ of $\mathrm{HgO}$ added to SB6-21 to 23 gave $16.36 \mathrm{~g}$ of elemental $\mathrm{Hg}$ fed. The ARP/MCU run, SB6-24, had $14.86 \mathrm{~g}$ of elemental $\mathrm{Hg}$ fed.

Mercury left the SRAT/SME vessel in several ways: 1) in slurry form, 2) in dissolved form, or 3) in elemental form. In the slurry form, potential pathways included SRAT cycle samples, SRAT product samples, and SME product samples. SME product samples, however, came after the mass of total SME product was determined. The SRAT product $\mathrm{Hg}$ analysis was used to calculate the Hg in the SRAT product samples. Samples prior to the end of the SRAT cycle were presumed to take a proportional quantity of the starting mercury with them (conservatively high estimate of $\mathrm{Hg}$ lost in samples).

Mercury left in dissolved form with various condensates (SRAT dewater, SME dewater, MWWT aqueous phase). All condensates from SB6-23, the 120\% acid case, were analyzed for dissolved $\mathrm{Hg}$ which may partly explain why it had the largest total amount of $\mathrm{Hg}$ found in the condensates. Condensate dissolved $\mathrm{Hg}$ only accounted for $2.2 \%$ of the $\mathrm{Hg}$ in SB6-23, however, so the condensates from the other tests were only selectively characterized for $\mathrm{Hg}$.

Mercury captured in elemental form (beads of $\mathrm{Hg}$ in the MWWT, in the dewater condensates, etc.) formed a third countable group. Mercury material balance results are summarized in Table 8 . 
Table 8. SRAT/SME mercury material balances

\begin{tabular}{|l|c|c|c|c|c|c|}
\hline Run & $\begin{array}{c}\text { Acid by } \\
\text { DWPF eqn. }\end{array}$ & $\begin{array}{c}\text { Slurry Hg } \\
\text { removals, } \\
\text { g }\end{array}$ & $\begin{array}{c}\text { All } \\
\text { Condensate } \\
\text { Hg, g }\end{array}$ & $\begin{array}{c}\text { MWWT } \\
\text { elemental } \\
\text { Hg, g }\end{array}$ & $\begin{array}{c}\text { Grams Hg } \\
\text { accounted } \\
\text { for }\end{array}$ & $\begin{array}{c}\text { \% Hg } \\
\text { accounted } \\
\text { for }\end{array}$ \\
\hline SB6-21 & $102 \%$ & 1.10 & 0.33 & 12.62 & 14.05 & $86 \%$ \\
\hline SB6-23 & $120 \%$ & 3.45 & 0.37 & 9.55 & 13.37 & $82 \%$ \\
\hline SB6-22 & $159 \%$ & 1.02 & 0.001 & $7.23^{\S}$ & 8.26 & $50 \%$ \\
\hline SB6-24 & $\begin{array}{c}\text { ARP } \\
(119 \%)\end{array}$ & 2.81 & 0.12 & 7.99 & 10.29 & $69 \%$ \\
\hline
\end{tabular}

$\S$ - this values includes $\sim 4.2 \mathrm{~g}$ recovered from deposits on the SRAT impeller blades

Mercury material balance closure was better than in recent SB6 testing in part due to the more thorough sampling and probably also to the increased vessel agitation levels. The trend in material balance closure versus acid stoichiometry was similar to recent SB6 data sets where higher acid stoichiometries correlated with more unidentified mercury losses.

Furthermore, $79 \%$ of the mercury in SB6-21 was found outside of the SRAT vessel, so at most $21 \%$ remained in the vessel (at most $3.41 \mathrm{~g} \mathrm{Hg}$ relative to about 2,320 $\mathrm{g}$ of SME product, or about $0.3 \mathrm{wt} \%$ in the SME total solids). The discovery and quantification of the mercury deposits on the SB6-22 impeller contributed greatly to accounting for more mercury in that test, even though only half of the initial mercury was located. The deposits accounted for half of the mercury that was found. As much as 80\% of the mercury in SB6-22 (highest acid) could still have been in the vessel at the end of the SME cycle.

\subsection{Process Sampling Results}

Samples were pulled following acid addition to characterize the slurry anion and supernate cation concentrations. Table 9 gives the percentages of elements that were essentially insoluble in the SB6-G simulant that partially dissolved during acid addition. The $\mathrm{pH}$ at the end of acid addition is also given as a benchmark, since some of the solubilities are believed to be driven by supernate $\mathrm{pH}$.

Table 9. Percentages of selected elements in supernate after acid addition

\begin{tabular}{|l|c|r|c|c|c|c|c|c|c|c|c|}
\hline Run & Acid & Ca & La & Mg & Mn & Ni & Rh & Ru & S & Si & pH \\
\hline SB6-21 & $102 \%$ & 100 & 1.6 & 35 & 52 & 12 & 59 & 10 & 65 & 1.1 & 4.47 \\
\hline SB6-23 & $120 \%$ & 97 & 3.2 & 46 & 68 & 23 & 77 & 20 & 75 & 0.9 & 4.55 \\
\hline SB6-22 & $159 \%$ & 100 & 9.0 & 53 & 92 & 46 & 9 & 16 & 73 & 1.8 & 4.07 \\
\hline SB6-24 & $\begin{array}{c}\text { ARP } \\
(119 \%)\end{array}$ & 45 & 2.8 & 49 & 72 & 14 & 49 & 11 & 91 & 1.1 & 4.99 \\
\hline
\end{tabular}

The species $\mathrm{La}, \mathrm{Mg}, \mathrm{Mn}$, and Ni showed increasing solubility with increasing acid stoichiometry (decreasing $\mathrm{pH}$ ), consistent with the results from the recent SRAT chemistry study, except for Mg. The previous SRAT chemistry testing with a simulant made with $\mathrm{Mg}(\mathrm{OH})_{2}$ showed nearly complete $\mathrm{Mg}$ dissolution prior to the end of acid addition that persisted into the reflux period. SB6-G simulant contains precipitated $\mathrm{Mg}$ salts, which were presumed to be $\mathrm{Mg}(\mathrm{OH})_{2}$, but which may be a mixture of multiple species. Oxalate in the ARP may have contributed to suppressing $\mathrm{Ca}$ dissolution in the ARP run. 
Two samples were pulled after acid addition for IC. Anions by IC from weighted dilutions of the SRAT slurry are given in Table 10.

Table 10. Slurry anions after acid addition, $\mathrm{mg} / \mathrm{kg}$

\begin{tabular}{|l|c|c|c|c|c|c|}
\hline Run & Acid & Nitrite & Nitrate & Formate & Sulfate & Chloride \\
\hline SB6-21 & $102 \%$ & 6,900 & 15,300 & 46,600 & 500 & 500 \\
\hline SB6-23 & $120 \%$ & 4,100 & 21,900 & 49,100 & 200 & 200 \\
\hline SB6-22 & $159 \%$ & $<400$ & 27,200 & 61,300 & 300 & 400 \\
\hline SB6-24 & $\begin{array}{c}\text { ARP } \\
(119 \%)\end{array}$ & 6,100 & 17,600 & 49,900 & 1,400 & 200 \\
\hline
\end{tabular}

The second IC sample after formic acid addition was used to check for ammonium ion. Less than detectable quantities of ammonium ion were found $(<5 \mathrm{mg} / \mathrm{L})$ in all four runs.

Anion reaction extents at the end of formic acid addition are given in Table 11. Nitrite lost is the percentage of the SB6-G nitrite destroyed by the end of acid addition. Nitrate gain/loss is the change in mass of total nitrate at the end of acid addition relative to the nitrate added as SB6-G simulant, $\mathrm{Pd}$ and $\mathrm{Rh}$ nitrate solutions, $\mathrm{AgNO}_{3}$, and nitric acid. Formate lost is the percentage of the formic acid addition formate no longer present at the end of acid addition.

Table 11. Slurry anion reactions through acid addition

\begin{tabular}{|l|c|c|c|c|}
\hline Run & $\begin{array}{c}\text { Acid by } \\
\text { DWPF eqn }\end{array}$ & $\begin{array}{c}\text { Nitrite } \\
\text { Lost }\end{array}$ & $\begin{array}{c}\text { Nitrate } \\
\text { Gain }\end{array}$ & $\begin{array}{c}\text { Formate } \\
\text { Lost }\end{array}$ \\
\hline SB6-21 & $102 \%$ & $44 \%$ & $6 \%$ & $6 \%$ \\
\hline SB6-23 & $120 \%$ & $67 \%$ & $19 \%$ & $11 \%$ \\
\hline SB6-22 & $159 \%$ & $>96 \%$ & $23 \%$ & $13 \%$ \\
\hline SB6-24 & ARP $(119 \%)$ & $41 \%$ & $14 \%$ & $3 \%$ \\
\hline
\end{tabular}

The small formate loss for SB6-24 is not realistic.

SRAT product supernate was analyzed for comparison to end of acid addition supernate. The extents of dissolution of selected elements are given in Table 12 as percentages of the total element slurry mass found in the supernate phase.

Table 12. Percentages of selected elements in SRAT product supernate

\begin{tabular}{|l|c|c|c|c|c|c|c|c|c|c|}
\hline Run & Acid & Ca & La & Mg & Mn & Ni & Rh & Ru & S & Si \\
\hline SB6-21 & $102 \%$ & 36 & $<0.1$ & 4 & 0.5 & $<0.1$ & 1.2 & $<0.1$ & 55 & 1.0 \\
\hline SB6-23 & $120 \%$ & 51 & $<0.1$ & 6 & 1.5 & $<0.1$ & 3.3 & $<0.1$ & 59 & 0.4 \\
\hline SB6-22 & $159 \%$ & 90 & $<0.1$ & 51 & 34 & $<0.1$ & 1.6 & 2 & 55 & 1.2 \\
\hline SB6-24 & $\begin{array}{c}\text { ARP } \\
(119 \%)\end{array}$ & 0.7 & $<0.1$ & 0.4 & 0.01 & $<0.1$ & 1.3 & $<0.1$ & 98 & 0.8 \\
\hline
\end{tabular}

Some unexpected results were obtained in the ARP/MCU run relative to the sludge-only runs. Virtually complete precipitation of $\mathrm{Ca}, \mathrm{Mg}$, and $\mathrm{Mn}$ occurred during reflux (see Table 9 for the end of acid where all of these elements were still soluble). In SB6-21 to 23, the solubilities of Ca, $\mathrm{Mg}$, and Mn tracked with the acid stoichiometry. Sulfur, presumably sulfate ion, was $50-60 \%$ soluble in the three regular runs and essentially $100 \%$ soluble in the ARP/MCU run. This shift in sulfate solubility, combined with the additional precipitation seen for $\mathrm{Ca}, \mathrm{Mg}$, and $\mathrm{Mn}$, suggests 
that some precipitated species shifted from sulfates to oxalates once sufficient oxalate was available (from the ARP).

General SRAT product properties and anion concentrations are given in Table 13. The calcined solid percent was determined after bringing the sample to $1100^{\circ} \mathrm{C}$. The $\mathrm{pH}$ was measured on room temperature samples.

Table 13. SRAT product properties

\begin{tabular}{|l|c|c|c|c|}
\hline & SB6-21 & SB6-22 & SB6-23 & SB6-24 \\
\hline $\mathrm{wt} \%$ total solids & 27.2 & 25.3 & 27.0 & 29.2 \\
\hline $\mathrm{wt} \%$ insoluble solids & 16.0 & 14.0 & 14.2 & 16.0 \\
\hline $\mathrm{wt} \%$ soluble solids & 11.2 & 11.3 & 12.8 & 13.2 \\
\hline $\mathrm{wt} \%$ calcined solids & 17.7 & 16.0 & 17.3 & 18.8 \\
\hline \hline Slurry density, g/mL & 1.191 & 1.188 & 1.266 & 1.222 \\
\hline Supernate density, $\mathrm{g} / \mathrm{mL}$ & 1.067 & 1.091 & 1.089 & 1.104 \\
\hline \hline $\mathrm{pH}$ at $25^{\circ} \mathrm{C}$ & 9.47 & 8.45 & 9.28 & 10.21 \\
\hline Fluoride, $\mathrm{mg} / \mathrm{kg}$ & $<100$ & $<100$ & $<100$ & $<100$ \\
\hline Chloride, $\mathrm{mg} / \mathrm{kg}$ & 440 & 600 & 550 & 550 \\
\hline Nitrite, $\mathrm{mg} / \mathrm{kg}$ & 90 & $<90$ & $<90$ & $<90$ \\
\hline Nitrate, $\mathrm{mg} / \mathrm{kg}$ & 22,000 & 26,300 & 28,000 & 27,100 \\
\hline Sulfate, $\mathrm{mg} / \mathrm{kg}$ & 700 & 520 & 640 & 2450 \\
\hline Formate, $\mathrm{mg} / \mathrm{kg}$ & 47,200 & 40,000 & 41,800 & 49,900 \\
\hline Phosphate, $\mathrm{mg} / \mathrm{kg}$ & $<100$ & $<100$ & $<100$ & $<100$ \\
\hline Ammonium, $\mathrm{mg} / \mathrm{L}$ & $<10$ & 591 & 25 & $<10$ \\
\hline
\end{tabular}

Total slurry elemental analysis for the four SRAT and four SME products are tabulated in Appendix A. The SRAT product anions were used to determine the percent formate loss, percent nitrite loss, and the net nitrite-to-nitrate conversion for the SRAT cycle. These quantities are summarized in Table 14. Formate lost is the difference between moles of SRAT product formate and moles of formic acid added, divided by moles of formic acid added. Nitrate gain/loss is moles of SRAT product nitrate minus all sources of nitrate addition (excluding nitrite-to-nitrate conversion), divided by the sources of nitrate addition.

Table 14. SRAT cycle anion reactions

\begin{tabular}{|l|c|c|c|c|c|c|}
\hline Run & $\begin{array}{c}\text { Acid by } \\
\text { DWPF eqn. }\end{array}$ & $\begin{array}{c}\text { Nitrite } \\
\text { Lost }\end{array}$ & $\begin{array}{c}\text { Net Nitrite- } \\
\text { to-Nitrate }\end{array}$ & $\begin{array}{c}\text { Nitrate } \\
\text { gain/(loss) }\end{array}$ & $\begin{array}{c}\text { Formate } \\
\text { Lost }\end{array}$ & $\begin{array}{c}\text { Formate } \\
\text { Lost, } \mathbf{g}\end{array}$ \\
\hline SB6-21 & $102 \%$ & $99.5 \%$ & $6 \%$ & $7 \%$ & $33 \%$ & 59 \\
\hline SB6-23 & $120 \%$ & $>99.5 \%$ & $9 \%$ & $8 \%$ & $46 \%$ & 93 \\
\hline SB6-22 & $159 \%$ & $>99.5 \%$ & $-15 \%$ & $(11 \%)$ & $58 \%$ & 153 \\
\hline SB6-24 & ARP (119\%) & $>99.5 \%$ & $2 \%$ & $2 \%$ & $38 \%$ & 71 \\
\hline
\end{tabular}

Nitrite was detected at $\sim 90 \mathrm{mg} / \mathrm{kg}$ in the SB6-21 SRAT product indicating that it was very close to the minimum stoichiometric acid requirement for successful nitrite destruction. Grams formate lost is given (at lab-scale) in addition to the percent, since progressively more formic acid was added as the stoichiometric factor increased. This column shows that while the relative formate loss from $113 \%$ to $150 \%$ acid increased by $26 \%,(58 \%-46 \%) / 46 \%$, the actual formate mass loss increased by $65 \%,(153-93) / 93$. Nitrate gain/loss was given in addition to the nitrite-to-nitrate conversion, since the negative nitrite-to-nitrate conversion lacked physical significance. 
The SRAT losses all have uncertainty due to the calculation of the SRAT product mass. The addition of the ammonia scrubber increased system pressure and led to increased fugitive moisture losses during the simulations, making the back calculation of the SRAT product mass more uncertain than it has been in the past. There is additional uncertainty in the formate results, since the samples sat in diluted form for about three weeks before they were analyzed. Dilute formate standard solutions are not stable over that period of time, but the diluted samples were at somewhat higher concentrations. The SRAT product mass was calculated using the weighed SME product mass plus the SME frit slurry addition masses, dewatering masses, sample masses, etc. and allowing for some losses to the off-gas during the SME cycle.

General SME product properties and anion concentrations are given in Table 15. The calcined solid percent was determined after bringing the sample to $1100{ }^{\circ} \mathrm{C}$. SME vessel pHs at $102{ }^{\circ} \mathrm{C}$ at the end of final dewatering ranged from 6.95 in SB6-22 to 8.31 in SB6-24. Anions were measured by AD, except for the formate ion in SB6-23 which was measured by PSAL.

Table 15. SME product properties

\begin{tabular}{|l|c|c|c|c|}
\hline & SB6-21 & SB6-22 & SB6-23 & SB6-24 \\
\hline wt\% total solids & 50.3 & 49.9 & 51.5 & 55.0 \\
\hline $\mathrm{wt} \%$ insoluble solids & 39.8 & 39.2 & 39.4 & 43.7 \\
\hline $\mathrm{wt} \%$ soluble solids & 10.5 & 10.7 & 12.1 & 11.3 \\
\hline $\mathrm{wt} \%$ calcined solids & 42.4 & 41.6 & 43.4 & 46.3 \\
\hline Slurry density, g/mL & 1.43 & 1.44 & 1.44 & 1.50 \\
\hline Supernate density, g/mL & 1.112 & 1.118 & 1.118 & 1.134 \\
\hline \hline $\mathrm{pH}$ at $25^{\circ} \mathrm{C}$ & 8.70 & 8.23 & 8.91 & 8.65 \\
\hline Fluoride, $\mathrm{mg} / \mathrm{kg}$ & $<100$ & $<100$ & $<100$ & $<100$ \\
\hline Chloride, $\mathrm{mg} / \mathrm{kg}$ & 450 & 450 & 440 & 470 \\
\hline Nitrite, $\mathrm{mg} / \mathrm{kg}$ & $<100$ & $<100$ & $<100$ & $<100$ \\
\hline Nitrate, $\mathrm{mg} / \mathrm{kg}$ & 19,000 & 23,200 & 23,600 & 21,600 \\
\hline Sulfate, $\mathrm{mg} / \mathrm{kg}$ & $<100$ & $<100$ & 119 & 171 \\
\hline Formate, $\mathrm{mg} / \mathrm{kg}$ & 39,900 & 45,000 & 45,900 & 40,900 \\
\hline Phosphate, $\mathrm{mg} / \mathrm{kg}$ & $<100$ & $<100$ & $<100$ & $<100$ \\
\hline
\end{tabular}

It is interesting that the SME product $\mathrm{pH}$ values were lower than the SRAT product $\mathrm{pH}$ values. Process $\mathrm{pH}$ data at boiling showed that the $\mathrm{pH}$ stayed fairly constant during the SME, perhaps falling by a tenth or two during the frit-formic slurry additions near the end of the SME. The $\mathrm{pH}$ readings at boiling were in the 6.9-8.3 range at the end of the SME (SB6-22 was lowest, and SB624 was highest).

The SME product wt \% total solids all exceeded the target of $48 \mathrm{wt} \%$. Investigation showed that this was caused by loss of water mass, and that the calcined solids masses of the four SME products were essentially as expected. The SME cycle nitrate and formate losses are given in Table 16. 
Table 16. SME cycle anion losses

\begin{tabular}{|l|c|c|c|}
\hline Run & $\begin{array}{c}\text { Acid by } \\
\text { DWPF eqn. }\end{array}$ & $\begin{array}{c}\text { Nitrate } \\
\text { Lost }\end{array}$ & $\begin{array}{c}\text { Formate } \\
\text { Lost }\end{array}$ \\
\hline SB6-21 & $102 \%$ & $4 \%$ & $14 \%$ \\
\hline SB6-23 & $120 \%$ & $13 \%$ & $-3 \%$ \\
\hline SB6-22 & $159 \%$ & $8 \%$ & -8 \\
\hline SB6-24 & ARP $(119 \%)$ & $17 \%$ & $22 \%$ \\
\hline
\end{tabular}

The SME cycle anion losses were subject to the uncertainty in the estimation of the SRAT product mass. Increasing the estimated SRAT product mass would move loss from the SME cycle to the SRAT cycle, while decreasing the estimated SRAT product mass would have the opposite effect. When combined with the normal analytical uncertainties, the nitrate and formate loss values presented have considerable accumulated potential uncertainty. In addition to normal analytical uncertainties, there are potential issues with sample degradation. Weighted dilutions of the SME cycle were held for about three weeks before analysis by AD. PSAL formate standards show degradation over similar time periods. Consequently, the formate results are not interpreted to mean that new formate ion was made in two of the SME cycles. It is more likely that the SRAT and/or SME results have larger error bars than normal.

The 17\% SME cycle nitrate loss in the ARP/MCU run is unusual and does not appear to be associated with an artificially high SRAT product analysis. Only $4.4 \mathrm{~g}$ of $\mathrm{CO}_{2}$ were detected in the SB6-24 SME cycle while the IC data from the SRAT and SME indicate $22 \mathrm{~g}$ of formate lost (which typically goes to $\mathrm{CO}_{2}$ ). It is possible that the SRAT formate loss was larger than indicated by the SRAT analysis, or that there was actually more formate in the SME product than indicated (or both). The low $\mathrm{CO}_{2}$ production is also inconsistent with the converting $17 \%$ of the nitrate in the SME to ammonium ion.

The extents of dissolution of selected elements at the end of the SME cycle are given in Table 17 as percentages of the total slurry element mass found in the supernate phase.

Table 17. Percentages of selected elements in SME product supernate

\begin{tabular}{|l|c|c|c|c|c|c|c|c|c|c|}
\hline Run & Acid & Ca & Li & Mg & Mn & Ni & Rh & Ru & S & Si \\
\hline SB6-21 & $102 \%$ & 55 & 1.7 & 12 & 3 & $<0.1$ & 1 & $<0.1$ & 71 & $<0.1$ \\
\hline SB6-23 & $120 \%$ & 35 & 1.2 & 5 & 2 & $<0.1$ & 2 & $<0.1$ & 73 & $<0.1$ \\
\hline SB6-22 & $159 \%$ & 78 & 1.5 & 42 & 31 & $<0.1$ & 1 & $<0.1$ & 68 & $<0.1$ \\
\hline SB6-24 & $\begin{array}{c}\text { ARP } \\
(119 \%)\end{array}$ & 1 & 2.2 & 1 & $<0.1$ & $<0.1$ & 1 & $<0.1$ & 100 & $<0.1$ \\
\hline
\end{tabular}

Clear trends were not as evident as in the SRAT products.

\subsection{Off-gas data}

Gas chromatography was used to analyze the composition of the off-gas downstream of the chilled condenser (FAVC). Because of the length of the SRAT cycle and the presence of a SME cycle, several different time axes were created to facilitate data comparisons. SRAT cycle hydrogen data are given in Figure 9 for the three different acid stoichiometries (values shown are from the Koopman minimum acid equation in this section). 
SRNL-STI-2010-00212

Revision 0

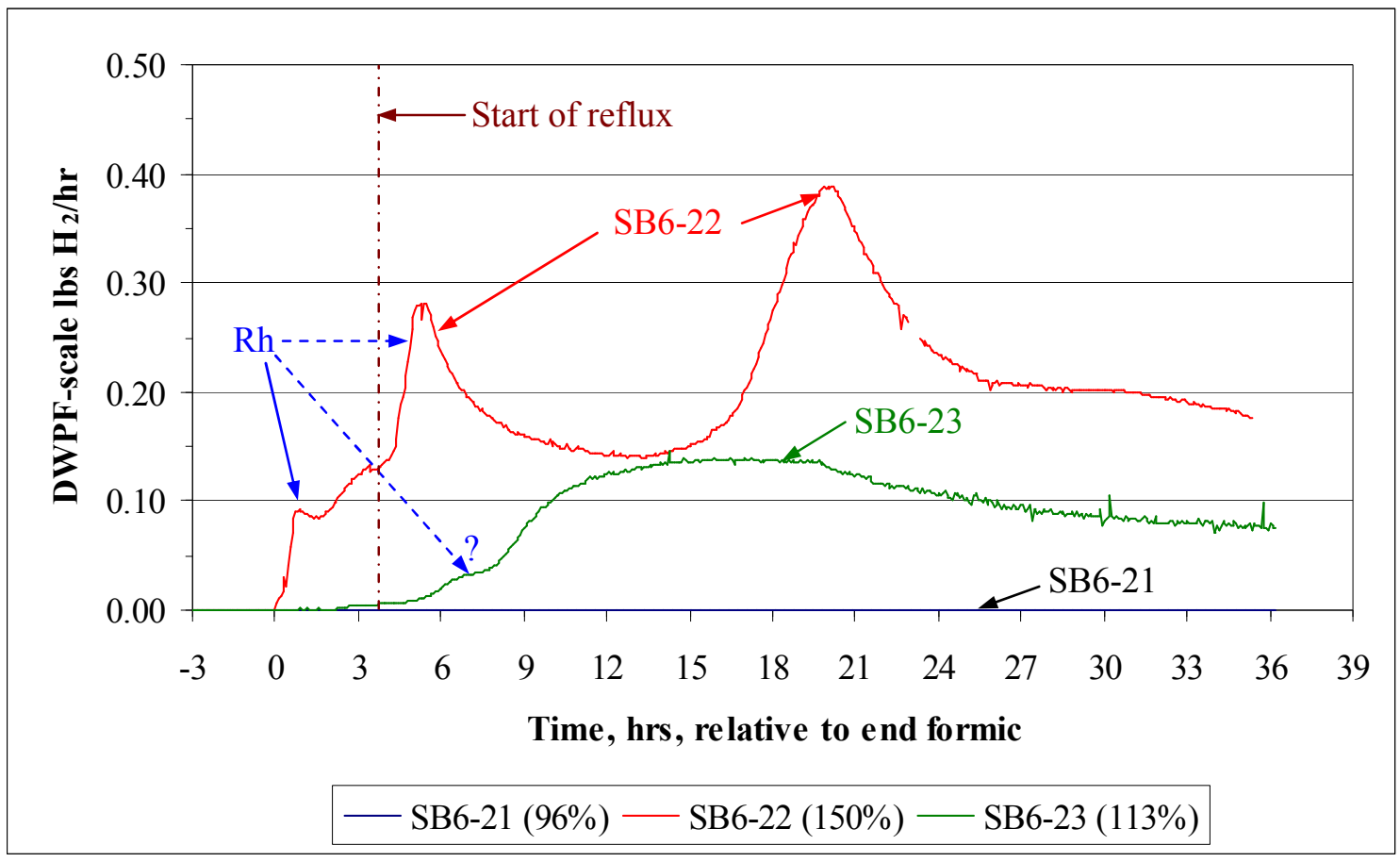

Figure 9. SRAT cycle hydrogen generation

The $150 \%$ acid stoichiometry run had two distinct peaks in hydrogen generation. The first came shortly after the start of reflux. This peak does not appear to have been a reinvigoration of Rh by nitrite accumulated in the MWWT during dewatering, since analysis of the dewatered condensate showed $<100 \mathrm{mg}$ nitrite/L. The second peak about 20 hours after the end of formic acid was presumably linked to the $\mathrm{Ru}$. The intermediate acid run had a single hydrogen peak about 16 hours after formic acid that was presumably due to $\mathrm{Ru}$. A shoulder on the SB6-23 curve at about 7 hours after formic acid corresponds with the period near the end of nitrite destruction based on the $\mathrm{NO}_{\mathrm{x}}$ data, and could be a failed attempt at a Rh-based hydrogen peak. The low acid run never produced detectable hydrogen generation even after nitrite destruction.

Hydrogen data from the SME cycle converted to DWPF-scale lbs/hr are given in Figure 10. 
SRNL-STI-2010-00212

Revision 0

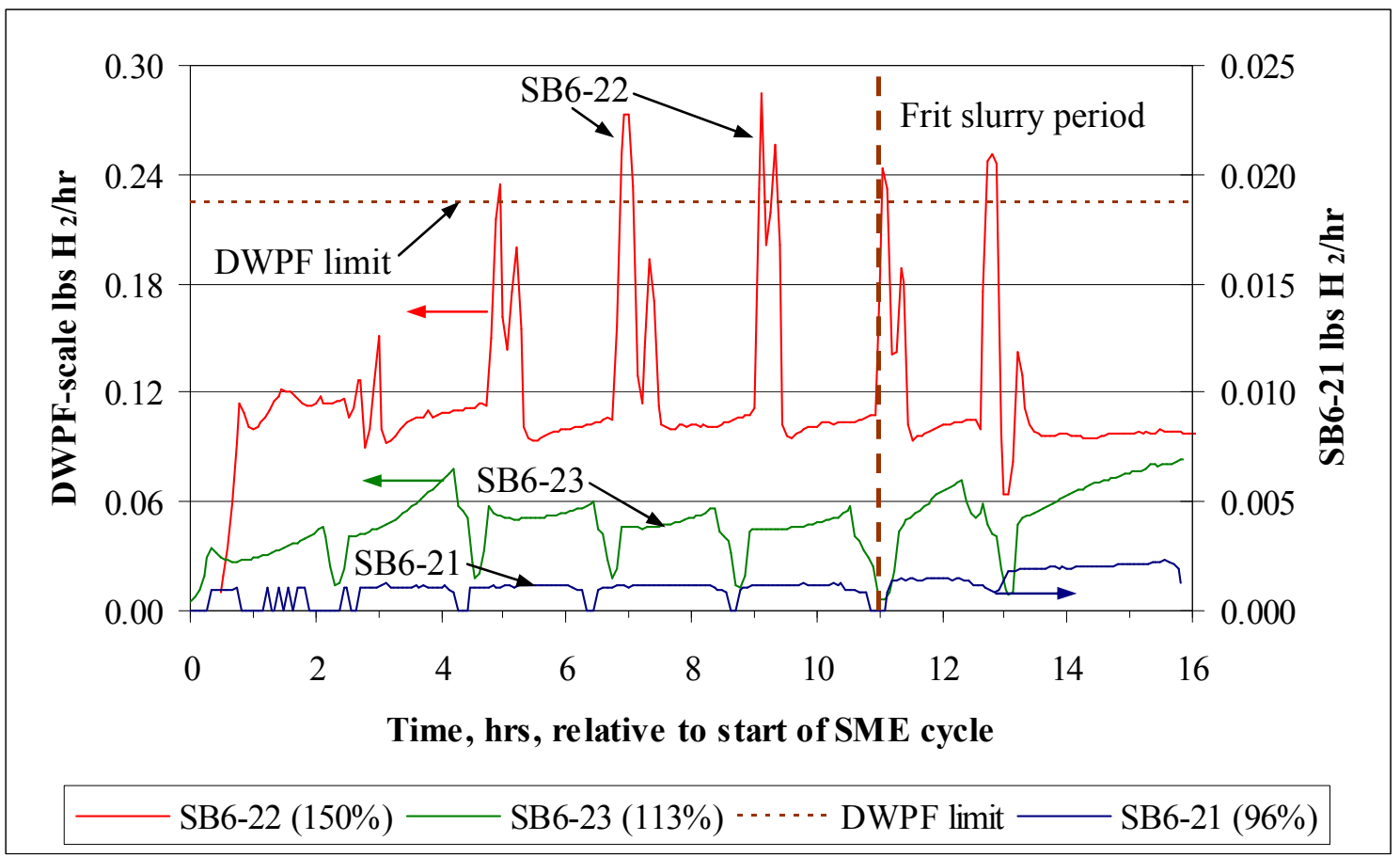

Figure 10. SME cycle hydrogen generation rates

Detectable hydrogen was finally seen in SB6-21 during the SME cycle, although a rescaled axis was needed to show the detail in the data. SB6-22 (150\%) had five brief surges above the DWPF SME cycle limit while decon water additions or frit slurry additions were being made. It is not clear whether or not the magnitude of the lab-scale surges was prototypical of the impact of DWPF SME cycle additions on off-gas concentrations. Generally SB6-22 stayed near half the DWPF SME cycle limit except during those five periods. The SB6 Shielded Cells SME cycle from SC-9 resembled the SB6-23 data in appearance. If necessary, DWPF could potentially increase acid stoichiometry above $120 \%$ by the DWPF acid equation if plant-scale experimentation showed that the observed surges are either absent or much less significant than in the lab-scale tests. SB6-23 with intermediate acid stoichiometry exhibited intermediate hydrogen generation rates. Hydrogen generation rates between bursts triggered by fresh additions to the SME held fairly constant except during the final dewatering of SB6-23.

SRAT cycle carbon dioxide data are given in Figure 11. 
SRNL-STI-2010-00212

Revision 0

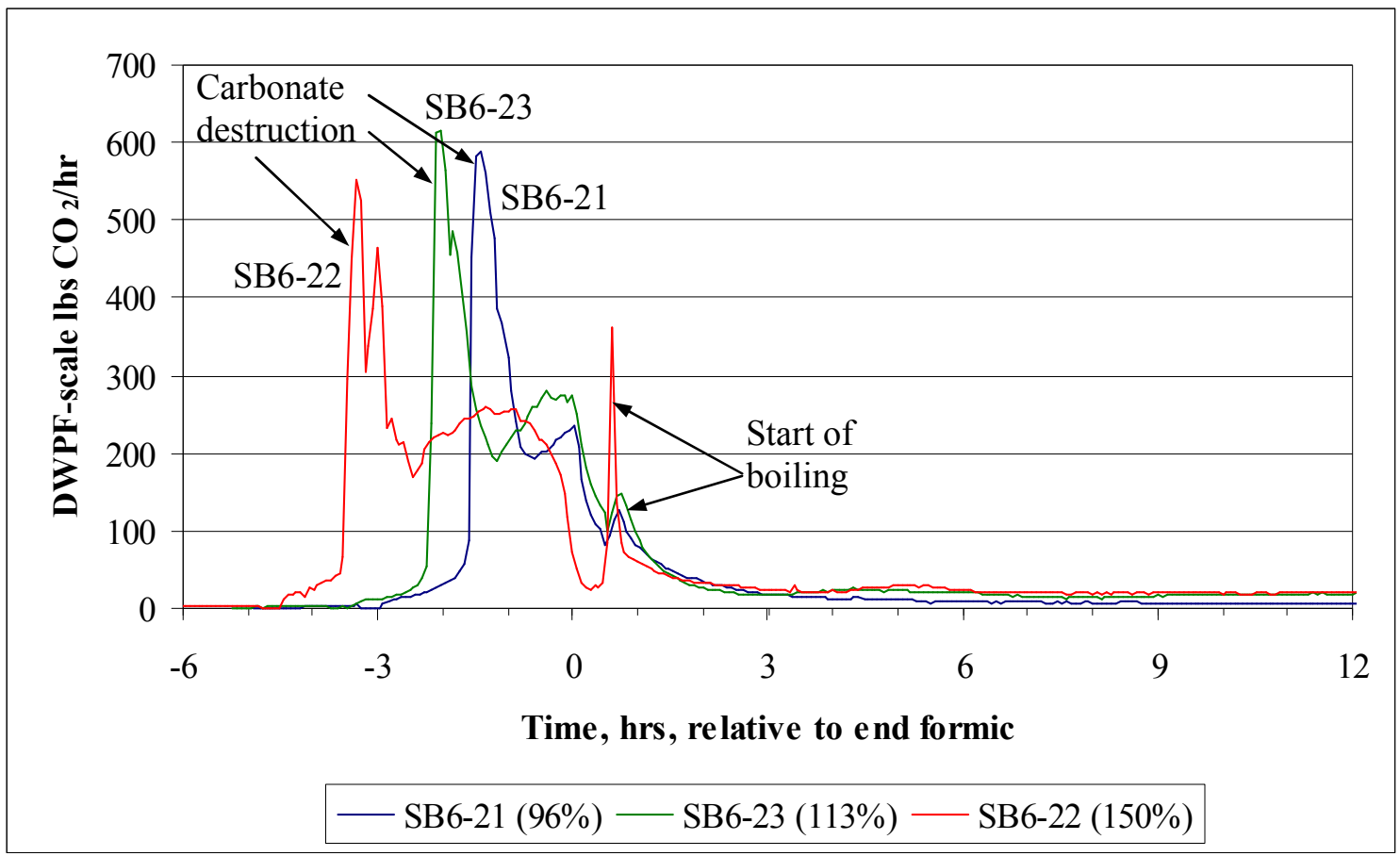

Figure 11. Carbon dioxide during acid addition, dewatering, and early reflux

Carbonate destruction included a split peak in SB6-22, a single peak in SB6-21, and a slightly split peak in SB6-23. The splits were not associated with the break between nitric acid and formic acid addition. The split may be associated with the duration and timing of mercury reduction in some fashion.

The $\mathrm{CO}_{2}$ generation following formic acid addition through reflux is shown in Figure 12. 


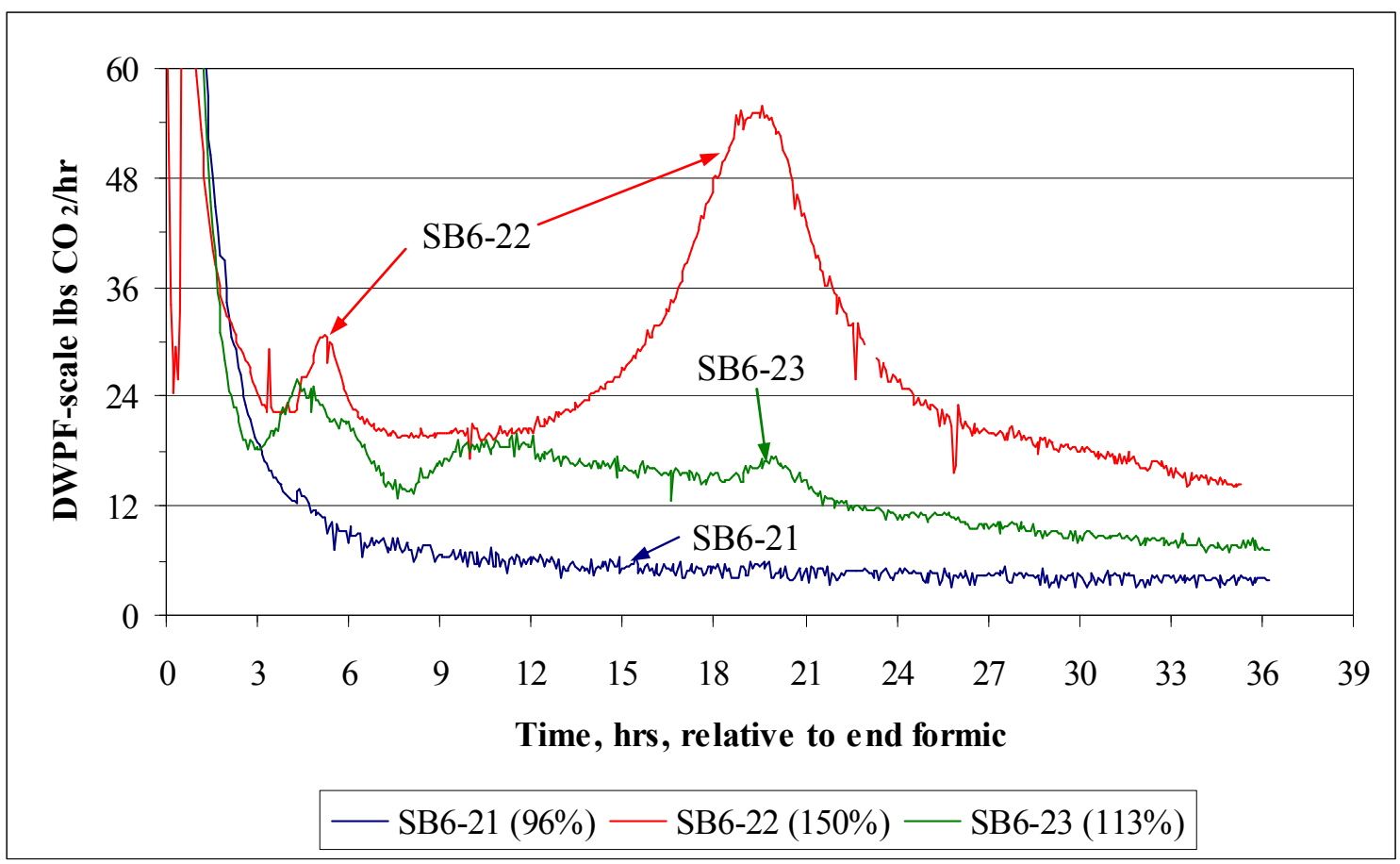

Figure 12. Carbon dioxide generation following formic acid addition

The two large peaks in $\mathrm{CO}_{2}$ production in SB6-22 aligned with the two main hydrogen generation rate peaks in Figure 9. SB6-21 $\mathrm{CO}_{2}$ production appeared to be in a near exponential decline following acid addition. SB6-21 data were probably from the slow destruction of nitrite ion combined with $\mathrm{CO}_{2}$ in the air purge. There was a lot of temporal structure in the SB6-23 data that was difficult to interpret (there were more large scale ups and downs than in the hydrogen data).

Formic acid can be destroyed by oxidation and decomposition (as well as other reactions). The two reactions are given by:

$$
\begin{aligned}
& \mathrm{HCOOH}+1 / 2 \mathrm{O}_{2} \rightarrow \mathrm{CO}_{2}+\mathrm{H}_{2} \mathrm{O} \\
& \mathrm{HCOOH} \rightarrow \mathrm{CO}_{2}+\mathrm{H}_{2}
\end{aligned}
$$

Forming a group containing twice the $\mathrm{O}_{2}$ flowrate plus the $\mathrm{CO}_{2}$ flowrate should give a constant flowrate if the only reaction impacting formic acid is oxidation. Similarly, forming a group containing the $\mathrm{CO}_{2}$ flowrate minus the $\mathrm{H}_{2}$ flowrate should give a constant (zero) flowrate if the only reaction impacting formic acid is decomposition. Forming the flowrate group $\left(2 * \mathrm{O}_{2}+\mathrm{CO}_{2}\right.$ $\mathrm{H}_{2}$ ) should give a constant flowrate if oxidation and decomposition are the only two reactions impacting formic acid. The data for SB6-21 and SB6-23 are given in Figure 13 in net moles/minute at lab scale. The actual plotted points are moving averages of five points centered at the time shown, two from just before the time, two from just after the time, and one from the same time. Averaging was done to smooth the curves, which otherwise are fairly noisy due to the accumulation of small random fluctuations in all three quantities in the sum. These two runs were paired because they used the same GC and MKS flow controllers. 
SRNL-STI-2010-00212

Revision 0

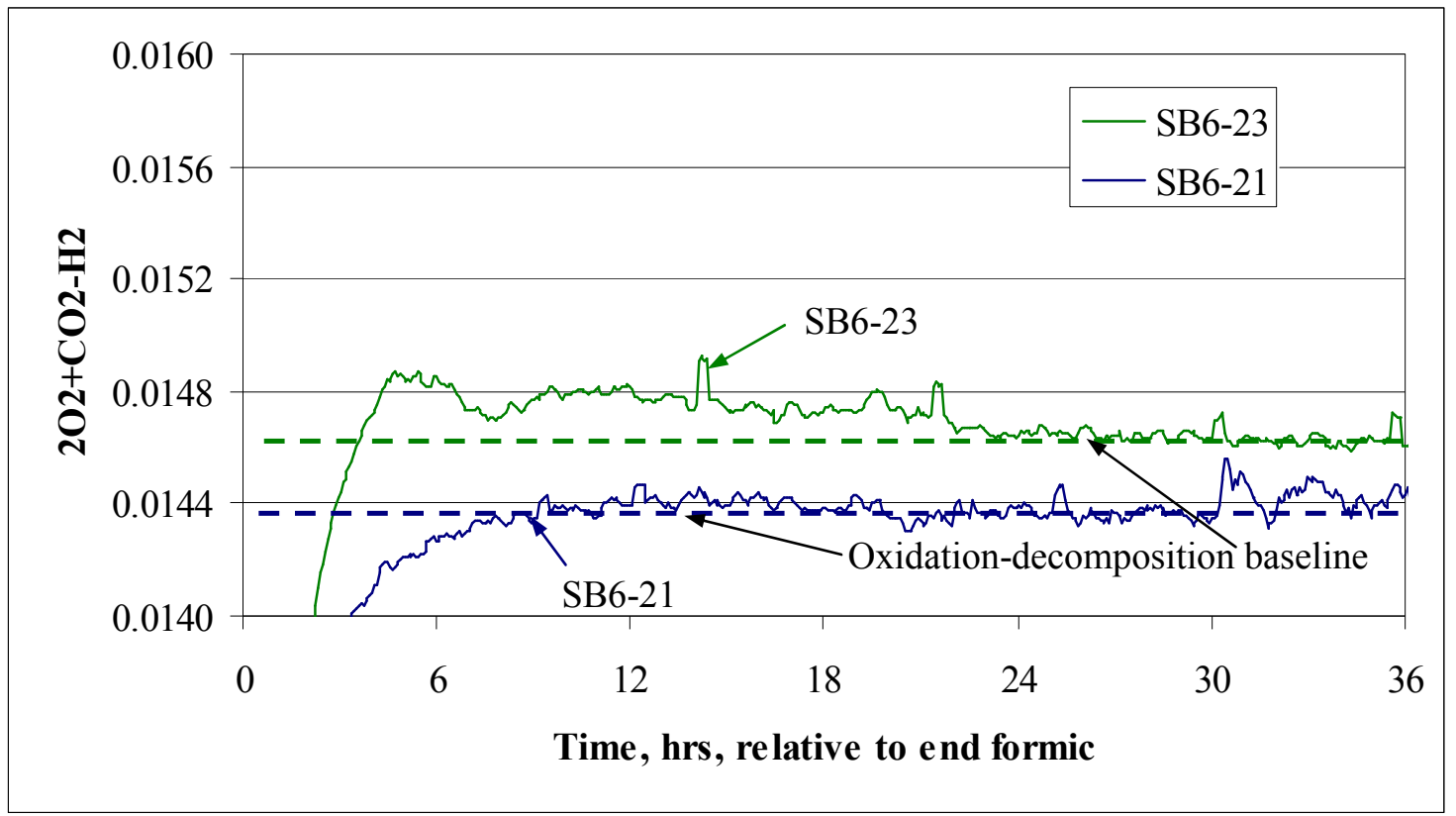

Figure 13. Net flowrate of $\left(2 * \mathrm{O}_{2}+\mathrm{CO}_{2}-\mathrm{H}_{2}\right)$ during boiling

Negligible deviation from a baseline set to the end of SRAT flowrate was seen in SB6-21 (low acid). Some excess $\mathrm{CO}_{2}$ production was indicated from about 4-24 hours after the end of formic acid addition in SB6-23 which may be associated with ammonium ion formation. A more comprehensive workup of the data from SB6-22 and SB6-23 is given in the ammonium ion discussion in Section 3.4.

$\mathrm{CO}_{2}$ production was seen during the SME cycles, and the data, converted to equivalent DWPFscale $\mathrm{lbs} / \mathrm{hr}$, are given in Figure 14. 


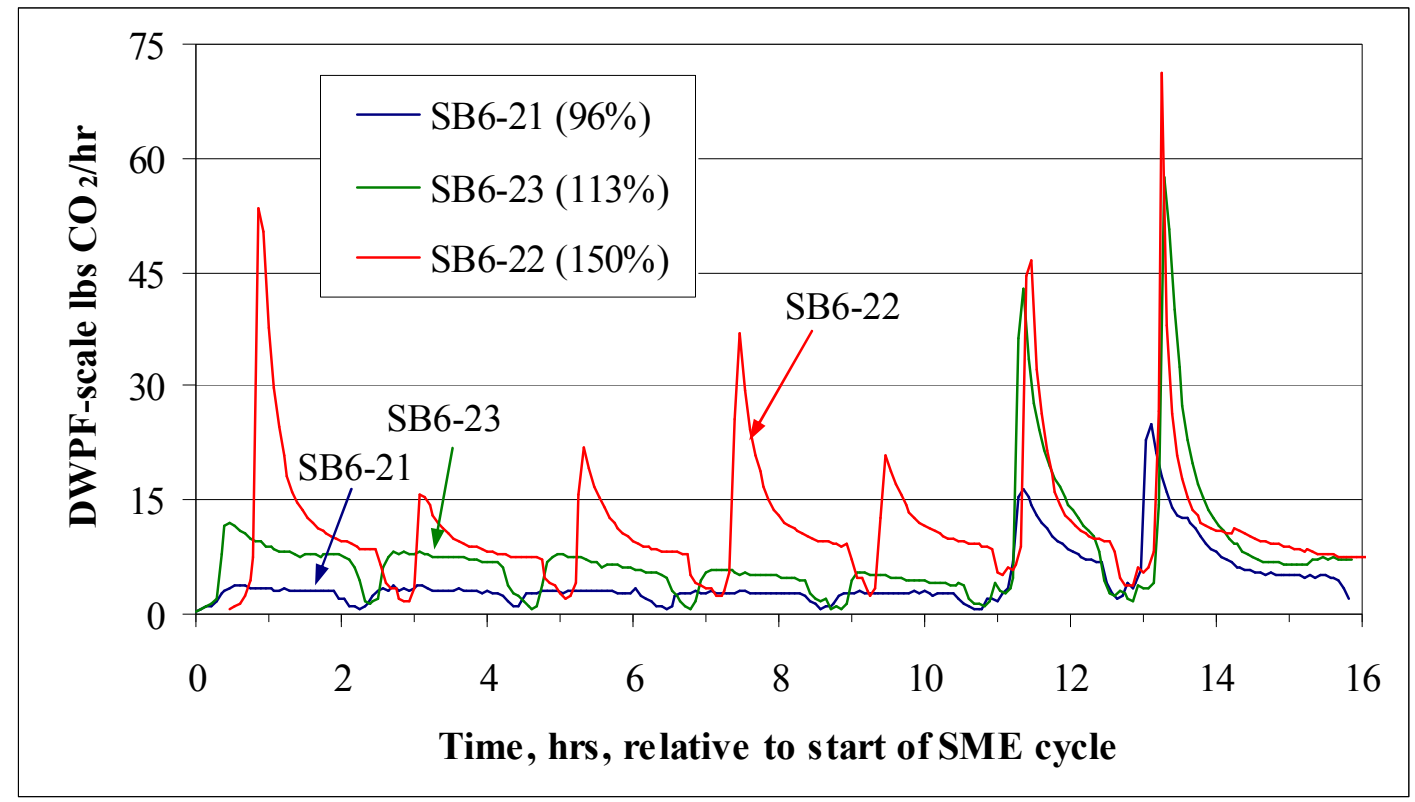

Figure 14. SME cycle carbon dioxide generation

The SME cycle carbon dioxide data appeared to be fairly typical of past SME simulations. Note that the SB6-22 $\mathrm{CO}_{2}$ peaks were not split into double peaks like the hydrogen peaks were. An explanation is still being sought for this difference. It is worth noting that $\mathrm{CO}_{2}$ generation picked up significantly in SB6-23 (113\%) following the two frit slurry additions that contained $1.5 \mathrm{wt} \%$ formic acid. Apparently, insufficient residual acid from the SRAT was present to trigger much catalytic activity during the five canister dewaterings that preceded the addition of the formic acid in the frit slurry.

The $\mathrm{N}_{2} \mathrm{O}$ generation rates during the early SRAT cycle are compared in Figure 15 . 
SRNL-STI-2010-00212

Revision 0

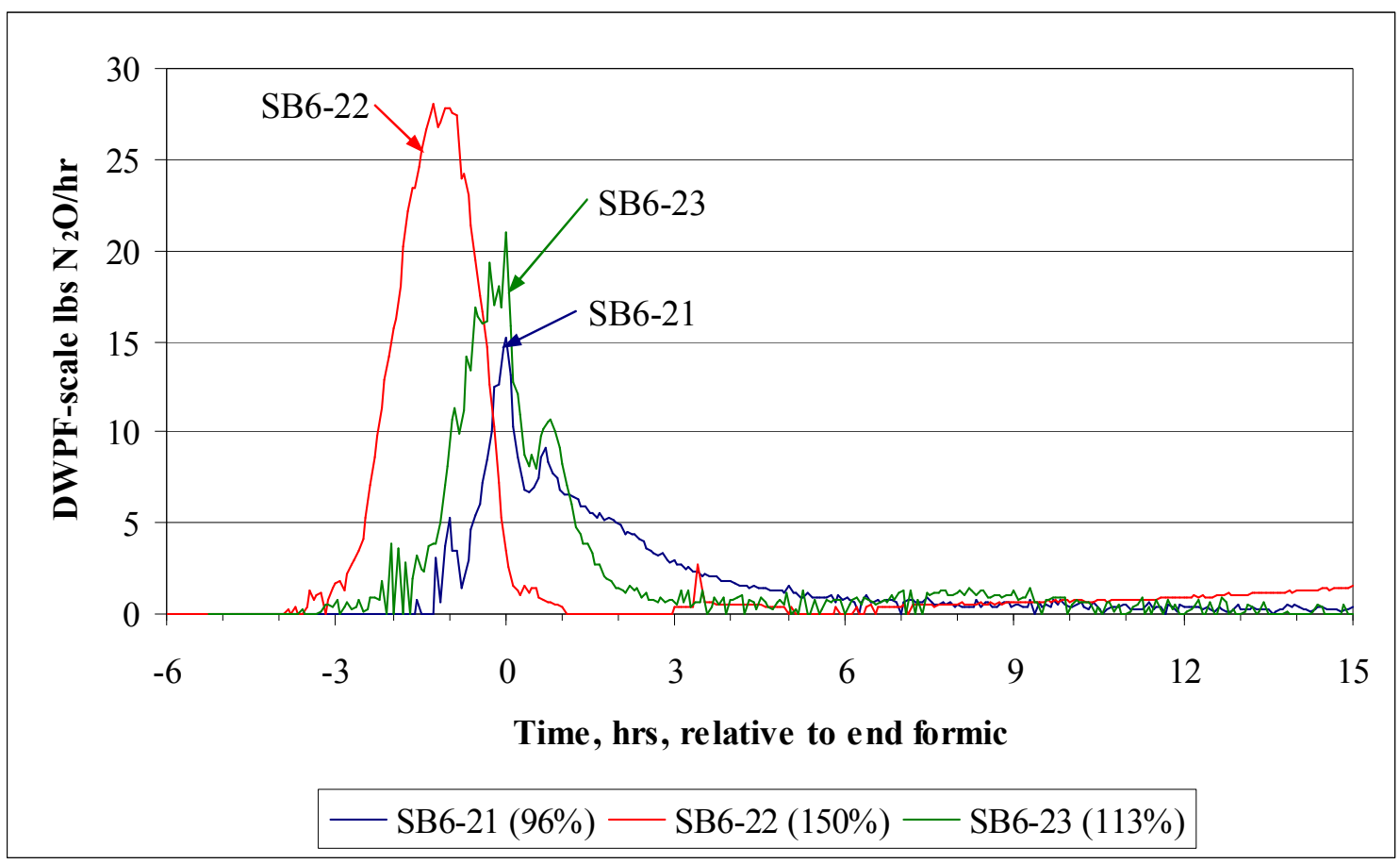

Figure 15. Nitrous oxide during SRAT acid addition and dewatering

The SB6-21 $\mathrm{N}_{2} \mathrm{O}$ production rate was in a nearly exponential decline following acid addition similar to the $\mathrm{CO}_{2}$ behavior in that run. Since nitrite was found in the SRAT product, it is likely that both the $\mathrm{N}_{2} \mathrm{O}$ and $\mathrm{CO}_{2}$ were associated with the declining rate of nitrite destruction as the acid and nitrite present at the end of acid addition were gradually consumed during boiling.

The amount of $\mathrm{N}_{2} \mathrm{O}$ produced in the Phase III SB6 simulant tests was low compared to earlier sludge batches such as SB4, but comparable to earlier SB6 work. The SB4 qualification simulant block of four SRAT simulations had peak $\mathrm{N}_{2} \mathrm{O}$ generation rates of $87-103 \mathrm{lb} / \mathrm{hr}$, versus the 14-28 $\mathrm{lb} / \mathrm{hr}$ range here. ${ }^{12}$ SB5 qualification simulant SRAT simulations had peaks in $\mathrm{N}_{2} \mathrm{O}$ of 45-55 $\mathrm{lbs} / \mathrm{hr} .{ }^{13}$ The difference is attributed to mercury, which has been shown to catalyze the conversion of nitrite to $\mathrm{NO}$ at the expense of $\mathrm{N}_{2} \mathrm{O}$ formation. Changes in noble metals also impact the results in different sludge batches. These changes impact the acid consumed to destroy nitrite ion (consumption increases as the catalytic reactions drive more of the destruction.)

The GC data were combined with the He internal standard flowrate and integrated over the SRAT cycle to produce total masses. Semi-quantitative estimates for $\mathrm{NO}_{2}$ and $\mathrm{NO}$ were prepared using oxygen consumption as a basis for $\mathrm{NO}_{2}$, and the historical ratio of $\mathrm{NO} / \mathrm{He}$ calibration factors to integrate the relatively small NO peaks. 
Table 18. GC relative masses of SRAT off-gas species in grams

\begin{tabular}{|l|c|l|c|c|c|c|}
\hline Run & $\begin{array}{c}\text { Acid - } \\
\text { Koopman }\end{array}$ & $\mathbf{H}_{\mathbf{2}}$ & $\mathbf{C O}_{\mathbf{2}}$ & $\mathbf{N}_{\mathbf{2}} \mathbf{O}$ & $\mathbf{N O}_{\mathbf{2}}$ & NO \\
\hline SB6-21 & $96 \%$ & 0.0 & 53.1 & 2.43 & 41 & 1.3 \\
\hline SB6-23 & $113 \%$ & 0.176 & 79.2 & 2.38 & 48 & 1.3 \\
\hline SB6-22 & $150 \%$ & 0.402 & 108.2 & 3.76 & 42 & 1.4 \\
\hline
\end{tabular}

There were some weak trends in the $\mathrm{N}_{2} \mathrm{O}$ data. Previous SB6 results had shown $\mathrm{N}_{2} \mathrm{O}$ production increasing as the acid stoichiometric factor increased. This trend generally signifies increasing catalytic attack on nitrite by mercury and noble metals as the quantity of formic acid added increases.

The range in total mass of carbon dioxide generated in the SRAT was large and consistent with the results seen in earlier SB6 testing. More than twice as much $\mathrm{CO}_{2}$ was produced at $150 \%$ acid compared to $96 \%$ acid (2.04 times as much). An increase in $\mathrm{CO}_{2}$ with increasing stoichiometry was expected here, since an increase by a factor of 2.13 was seen from $100 \%$ to $150 \%$ in the qualification simulant testing. ${ }^{15}$ The likely explanation is the additional $\mathrm{CO}_{2}$ produced during ammonia formation. The $\mathrm{CO}_{2}$ masses are smaller than the formate losses. This, along with the $\mathrm{pH}$ data around seven during reflux, typically indicates that there was carbonate formation in the SRAT during reflux in which formate converted to $\mathrm{CO}_{2}$ was absorbed into the slurry supernate as either carbonate or bicarbonate.

Hydrogen mass data were as expected. More hydrogen was produced as the stoichiometric factor increased. SB6-21 was essentially at minimum acid, since the GC data indicated nitrite destruction was still occurring at the end of the SRAT cycle. Detectable hydrogen did not appear until the SME cycle.

The cation, anion and GC data were combined to prepare a molar balance for nitrogen (excluding $\mathrm{N}_{2}$ gas). Table 18 summarizes the nitrogen inputs to the SRAT. The nitrite and nitrate include analytical uncertainties of about $10 \%$ from the IC analysis, or about \pm 0.11 moles in the sum.

Table 19. Nitrogen input species to SRAT, as moles $\mathbf{N}$

\begin{tabular}{|l|c|c|c|c|c|c|}
\hline Run & $\begin{array}{c}\text { Acid - } \\
\text { Koopman }\end{array}$ & $\begin{array}{c}\text { Sludge } \\
\text { Nitrate }\end{array}$ & $\begin{array}{c}\text { Trim } \\
\text { Nitrate }\end{array}$ & $\begin{array}{c}\text { Sludge } \\
\text { Nitrite }\end{array}$ & $\begin{array}{c}\text { Nitric } \\
\text { Acid }\end{array}$ & Sum In \\
\hline SB6-21 & $96 \%$ & 0.414 & 0.004 & 0.970 & 0.420 & 1.808 \\
\hline SB6-23 & $113 \%$ & 0.414 & 0.004 & 0.970 & 0.667 & 2.055 \\
\hline SB6-22 & $150 \%$ & 0.414 & 0.004 & 0.970 & 0.917 & 2.305 \\
\hline
\end{tabular}

Table 19 contains terms for measured nitrogen species leaving the SRAT. Nitrate plus nitrite includes the sum of the two species in the SRAT product along with the SRAT dewater condensate. Ammonium includes ammonium ion in both the SRAT product, FAVC condensate, and scrubber reservoir. These terms and the off-gas $\mathrm{N}_{2} \mathrm{O}$ have analytical uncertainties of order $10 \%$ or \pm 0.1 moles. The $\mathrm{NO}+\mathrm{NO}_{2}$ term has uncertainty estimated to be of order $20 \%$ or \pm 0.20 moles. A small amount of nitrate in the FAVC was not quantified, but could easily be of order 0.1 mole. 
Table 20. Nitrogen species leaving SRAT, as moles $\mathbf{N}$

\begin{tabular}{|l|c|c|c|c|c|c|}
\hline Run & $\begin{array}{c}\text { Acid - } \\
\text { Koopman }\end{array}$ & $\begin{array}{c}\text { Nitrate }+ \\
\text { nitrate }\end{array}$ & $\mathbf{N H}_{\mathbf{4}}{ }^{+}$ & $\mathbf{N}_{\mathbf{2}} \mathbf{O}$ & $\begin{array}{c}\mathbf{N O}_{\mathbf{2}}{ }^{+} \\
\text {NO }\end{array}$ & Sum Out \\
\hline SB6-21 & $96 \%$ & 0.903 & 0.001 & 0.110 & 0.935 & 2.029 \\
\hline SB6-23 & $113 \%$ & 1.174 & 0.062 & 0.108 & 1.087 & 2.440 \\
\hline SB6-22 & $150 \%$ & 1.187 & 0.132 & 0.171 & 0.948 & 2.438 \\
\hline
\end{tabular}

The inputs and outputs are combined in Table 20. Uncertainty in the inputs and outputs are cumulative, or of order 0.37 moles nitrogen per run, which tends to overwhelm the nitrogen material balance closure estimation. Delta is ((moles in - moles out $) /($ moles in $))^{*} 100 \%$.

Table 21. SRAT nitrogen balance summary

\begin{tabular}{|l|c|c|c|c|}
\hline Run & $\begin{array}{c}\text { Acid - } \\
\text { Koopman }\end{array}$ & Moles In & Moles Out & Delta \\
\hline SB6-21 & $96 \%$ & 1.808 & 2.029 & $-12.2 \%$ \\
\hline SB6-23 & $113 \%$ & 2.055 & 2.440 & $-18.7 \%$ \\
\hline SB6-22 & $150 \%$ & 2.305 & 2.438 & $-5.8 \%$ \\
\hline
\end{tabular}

In all three cases, the summation of outlet nitrogen exceeded the sum of input terms. This trend may indicate that the SB6-G sludge nitrite and/or nitrate values are biased low. Another possibility is that the estimates for nitrogen bearing species concentrations in the SRAT slurry samples were too high. The SB6-23 difference was just larger than the expected uncertainty in the measurements. Another possibility is that the calculated $\mathrm{NO}_{2}$ gas production, which is derived from the consumption of oxygen, is not the only reaction process that is consuming oxygen. An error in this assumption would lead to overstating the quantity of $\mathrm{NO}_{2}$ out. Nitrate and $\mathrm{NO}_{2}$ out are the two major sources of moles nitrogen out, each accounting for about $40-50 \%$ of the total. $\mathrm{NO}, \mathrm{N}_{2} \mathrm{O}$, nitrite ion, and ammonium ion combined made up only about $10-20 \%$ of the total moles out.

\subsection{Ammonium Ion Formation}

Significant ammonium ion content was found in the SB6 Phase II flowsheet study ${ }^{14}$ SRAT run at $150 \%$ acid stoichiometry. The SB6 qualification simulant testing confirmed the formation of significant ammonium ion at the mercury and noble metal levels being used, as well as that the quantity depended on acid stoichiometry. ${ }^{15}$ Runs with significant ammonium ion formation tended to have negative values for the calculated nitrite-to-nitrate conversion percentage, indicating a net loss of nitrate ion. Formate losses and $\mathrm{CO}_{2}$ production were fairly high at the higher acid stoichiometries. SB6-22 at 150\% acid was the primary example in this block of tests.

The formation of ammonia from nitrate is presumed to be a multi-step reaction with the overall stoichiometry below:

$$
5 \mathrm{HCO}_{2} \mathrm{H}+\mathrm{NO}_{3}^{-} \rightarrow \mathrm{NH}_{3}+\mathrm{HCO}_{2}^{-}+4 \mathrm{CO}_{2}+3 \mathrm{H}_{2} \mathrm{O}
$$

An equivalent, alternate form of this equation more appropriate for lower $\mathrm{pH}$ values is:

$$
4 \mathrm{HCO}_{2} \mathrm{H}+\mathrm{HNO}_{3} \rightarrow \mathrm{NH}_{3}+4 \mathrm{CO}_{2}+3 \mathrm{H}_{2} \mathrm{O}
$$


In either case, nitrate to ammonia conversion is a reduction reaction. Nitrogen goes from the +5 oxidation state in nitrate to the -3 oxidation state in ammonia (net change in oxidation state of eight). This is consistent with the conversion of four formic acid molecules to $\mathrm{CO}_{2}$, with a change of two in nitrogen oxidation state for each formic acid molecule destroyed. Literature articles have the nitrate adsorbing onto a catalytic substrate where the oxygen atoms are sequentially stripped and then replaced with hydrogen atoms. The initial overall reaction above can be broken down into at least three sequential reactions:

$$
\begin{aligned}
& \mathrm{HCO}_{2} \mathrm{H}+\mathrm{NO}_{3}^{-} \rightarrow \mathrm{NO}_{2}^{-}+\mathrm{CO}_{2}+\mathrm{H}_{2} \mathrm{O} \\
& 3 \mathrm{HCO}_{2} \mathrm{H}+2 \mathrm{NO}_{2}^{-} \rightarrow 2 \mathrm{NO}+2 \mathrm{HCO}_{2}^{-}+\mathrm{CO}_{2}+2 \mathrm{H}_{2} \mathrm{O} \\
& 5 \mathrm{HCO}_{2} \mathrm{H}+2 \mathrm{NO} \rightarrow 2 \mathrm{NH}_{3}+5 \mathrm{CO}_{2}+2 \mathrm{H}_{2} \mathrm{O}
\end{aligned}
$$

These three reactions sum to the overall reaction above (after dividing through by two). The middle reaction is one of the three reactions normally written for nitrite destruction in the SRAT cycle. In any case, the proposed mechanism has nitrate ion, nitrite ion, neutral $\mathrm{NO}$, and neutral $\mathrm{NH}_{3}$ adsorbed on the catalyst in sequence as the nitrate is converted to $\mathrm{NH}_{3}$. Not all destroyed nitrate ion must end up as $\mathrm{NH}_{3}$. Some of the nitrate could desorb from the catalyst as nitrite ion, $\mathrm{NO}$, or even $\mathrm{N}_{2}$, potentially as:

$$
2 \mathrm{HCO}_{2} \mathrm{H}+2 \mathrm{NO} \rightarrow \mathrm{N}_{2}+2 \mathrm{CO}_{2}+2 \mathrm{H}_{2} \mathrm{O}
$$

Liberation of nitrite ion, $\mathrm{NO}$, or $\mathrm{N}_{2}$ from the catalyst would represent nitrate lost but not converted into ammonia. Contemporary research is focused on developing catalysts for treating nitrate and nitrite waste waters that selectively promote $\mathrm{N}_{2}$ formation over $\mathrm{NH}_{3}$ formation. These papers indicate that simple catalysts generally produce a mixture of both species from adsorbed NO. The analytical test by IC cations is for ammonium ion (as opposed to dissolved molecular ammonia), so the presumed species are ammonium nitrate and formate in the SRAT and SME slurries, ammonium nitrate in the ammonia scrubber acid solution and in the FAVC condensate, and perhaps ammonium hydroxide in the SME condensates.

Ammonium ion formation was again observed in the SB6 Phase III flowsheet testing, but the levels were lower than in the earlier SB6 simulant testing. One likely explanation is the reduced mercury content of the trimmed SB6-G simulant (2.7\% versus $3.5-3.9 \%$ in the earlier testing). Nevertheless, ammonium ion formation was observed in SB6-21 to 24, and the most was found in the high acid run, SB6-22. The analysis of $2 \mathrm{O}_{2}+\mathrm{CO}_{2}-\mathrm{H}_{2}$ demonstrated in Section 3.3 was combined with $\mathrm{pH}$ data and SRAT slurry ammonium ion concentration results to produce Figure 16. The ammonium concentration in the SRAT slurry is given in 100's mg ammonium/ $/ \mathrm{kg}$ slurry, i.e. the maximum measured value was $1,020 \mathrm{mg}$ ammonium $/ \mathrm{kg}$ slurry at 25.34 hours which is shown as 10.2 in Figure 16. 


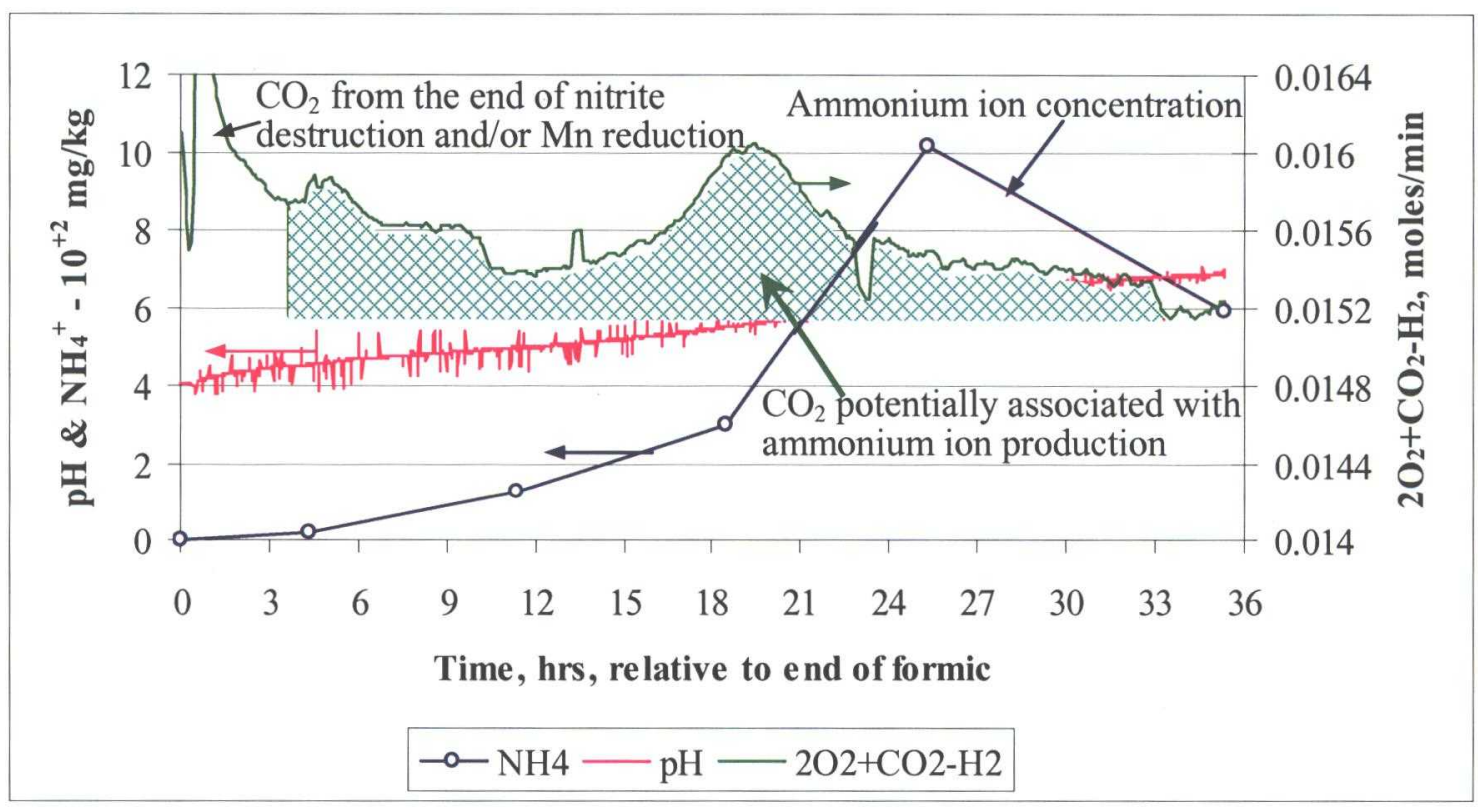

Figure 16. Net flowrate of $\left(2 * \mathrm{O}_{2}+\mathrm{CO}_{2}-\mathrm{H}_{2}\right)$ during boiling in SB6-22

The area of the region between the $2 \mathrm{O}_{2}+\mathrm{CO}_{2}-\mathrm{H}_{2}$ curve and the inferred maximum baseline rate of 0.01513 moles/minute was determined by integration of the $2 \mathrm{O}_{2}+\mathrm{CO}_{2}-\mathrm{H}_{2}$ curve and then subtracting the area under the baseline for the period from 3.8 to 34 hours (the cross-hatched region which was chosen to hopefully exclude $\mathrm{CO}_{2}$ from nitrite destruction or $\mathrm{Mn}$ reduction).

The resulting area was equivalent to 0.963 moles of excess $\mathrm{CO}_{2}$ above the oxidation and decomposition background discussed in Section 3.3. Formation of this quantity of $\mathrm{CO}_{2}$ could occur simultaneously with the formation of $4.34 \mathrm{~g}$ of ammonium ion by the reactions given above. An ammonium ion concentration of $1,638 \mathrm{mg} / \mathrm{kg}$ SRAT reflux slurry could be formed from this mass of ammonium ion. This concentration is $60 \%$ larger than any measured value during SB622. It indicates that the off-gas data are not obviously contradicting the liquid phase results or the presumed reaction pathway for ammonium ion formation. The predicted amount of potential ammonium ion formation could be increased by lowering the horizontal baseline at 0.01513 moles/min. The baseline implicitly assumed that excess $\mathrm{CO}_{2}$ generation stopped about 34 hours after formic acid addition, when in fact excess $\mathrm{CO}_{2}$ production may have been ongoing through to the end of the SRAT. The value chosen was intended to be conservative, that is, to not intentionally overstate the potential amount of $\mathrm{CO}_{2}$ production from ammonium ion formation.

The data analysis in Figure 16 also shows that the slurry ammonium ion concentration began to fall toward the end of the reflux period. It appears that the slurry $\mathrm{pH}$, as measured under temperature (may not be absolutely accurate), was above six and perhaps nearing seven as the ammonium concentration was falling. This period is presumably one during which significant ammonia vapor was released from the SRAT slurry and driven into the off-gas system. The $\mathrm{pH}$ data for this run were somewhat unusual in terms of the amount of recorded noise in the signal which is sometimes associated with ground fault issues with the probe reading (in which case the $\mathrm{pH}$ data may be biased high or low in addition to being noisy). 
Production of ammonium ion apparently started sometime during dewatering. The likely period of Rh dominated hydrogen formation fell in this period also (first six hours after formic acid). Once hydrogen generation shifted from $\mathrm{Rh}$ to $\mathrm{Ru}$ driven catalysis, it appeared that the ammonium ion formation rate increased (based on the rate of increase of ammonium ion in the slurry, since little was apparently being off-gassed at this time based on scrubber data).

$\mathrm{N}_{2} \mathrm{O}$ generation rate data and the time dependent integration of the molar off-gas group, $2 \mathrm{O}_{2}+\mathrm{CO}_{2}-\mathrm{H}_{2}$, were added to Figure 16 to further develop the chemistry of ammonium ion formation, Figure 17. The $\mathrm{N}_{2} \mathrm{O}$ data are in DWPF-scale $\mathrm{lbs} / \mathrm{hr}$ in order to align them to the left axis units.

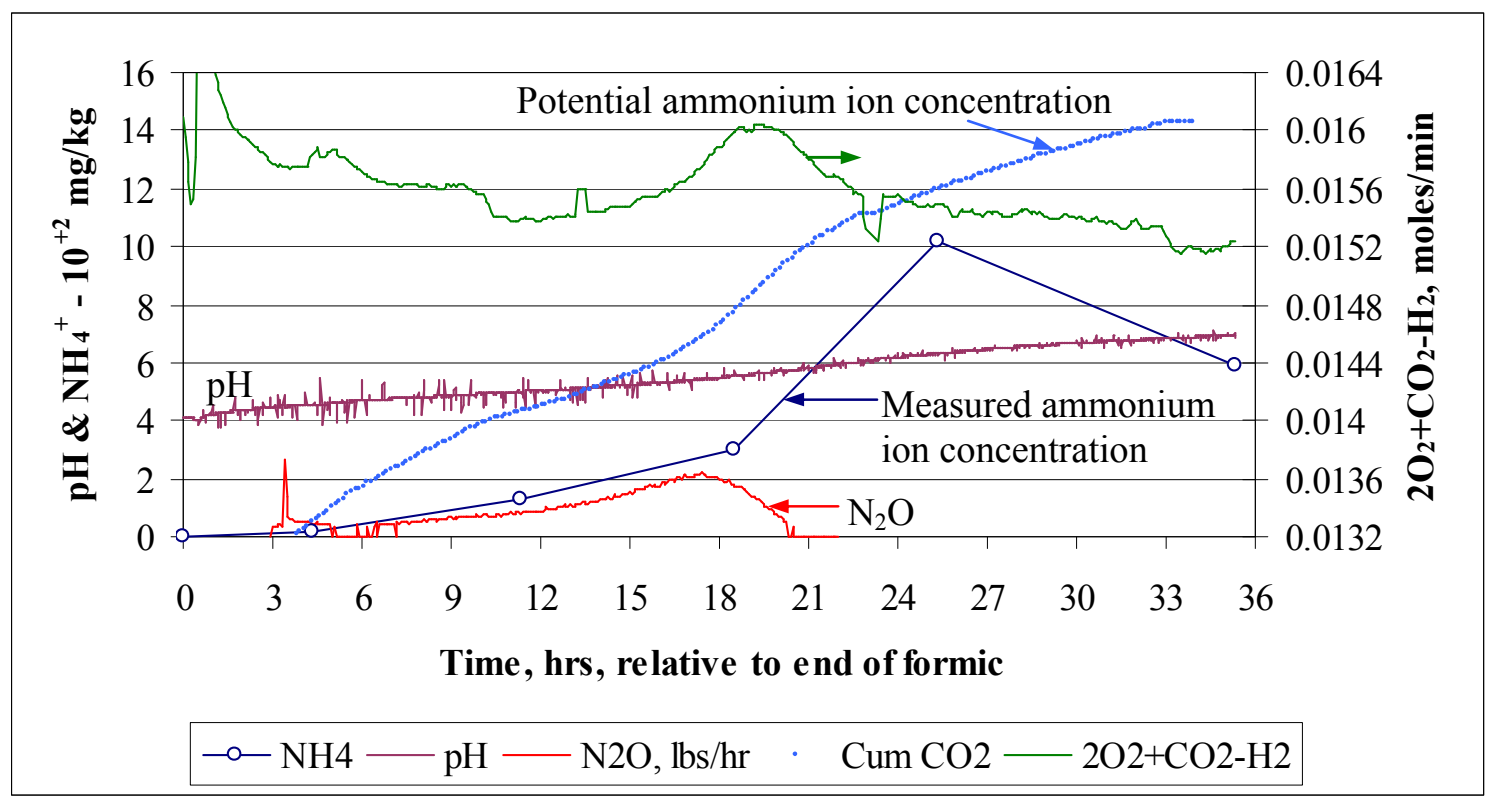

Figure 17. Expanded timeline development for SB6-22 ammonia

The dashed blue line from excess $\mathrm{CO}_{2}$ generation initially develops at a faster rate than the ammonium ion concentration in the SRAT slurry (the curve has been scaled to end at $1,430 \mathrm{mg}$ ammonium ion $/ \mathrm{kg}$ slurry, so it is actually the average potential formation rate of ammonium ion rather than the release rate of $\mathrm{CO}_{2}$ ). Simultaneously, the generation rate of $\mathrm{N}_{2} \mathrm{O}$ begins to increase until about 17 hours after formic acid addition. At that point the $\mathrm{pH}$ reaches about 5.5, and the rate of $\mathrm{N}_{2} \mathrm{O}$ formation falls off to zero over the next several hours.

An explanation for Figure 17 comes from the sequence of three reactions given at the beginning of this section.

1. As the SRAT initially became catalytically active for nitrate consumption, the $\mathrm{pH}$ of the slurry was too low for the nitrite being formed in the first reaction step to be $100 \%$ retained on the catalyst surface. The fraction of nitrite that desorbed back into the aqueous phase was destroyed by excess acid to produce $\mathrm{N}_{2} \mathrm{O}$ (and $\mathrm{NO}$ which is not being well tracked at this point). Potentially, some of the NO produced in the second reaction step may also have been desorbing rather than being converted to ammonium ion. Consequently, the initial rate of ammonium ion formation was less than could be explained by the amount of excess $\mathrm{CO}_{2}$ production. 
2. As the $\mathrm{pH}$ continued to rise, however, the equilibrium adsorption constants of the intermediates in the ammonium ion formation reaction scheme apparently shifted such that the intermediates were more strongly held by the catalyst. As desorption of intermediates fell, a higher fraction of the nitrate reacted all the way through the sequence to form ammonium. This period seemed to start at about 18 hours after formic acid addition and continued to the end of the SME cycle. The slopes of the ammonium ion concentration and excess $\mathrm{CO}_{2}$ curves became essentially parallel. During this period of efficient conversion of nitrate to ammonium ion, the $\mathrm{pH}$ continued to rise due to consumption of formic acid by the three reactions.

3. As $\mathrm{pH}$ rises, the solubility of ammonium ion is known to fall in aqueous systems. In SB6-22, some time around 25 hours after formic acid addition the ammonium ion concentration started to fall (and ammonia vapor became a significant part of the off-gas leaving the SRAT). The $\mathrm{pH}$ was about 6.5 when this occurred. At 26 hours after formic, there were 0.03 grams of ammonium collected by the ammonia scrubber. By the end of the SRAT cycle about 35 hours after formic, that had increased to $0.72 \mathrm{~g}$ of ammonium. The SRAT cycle ended with $1.57 \mathrm{~g}$ in the slurry, or about $65 \%$ of the $2.30 \mathrm{~g}$ total collected (ignoring perhaps $0.14 \mathrm{~g}$ more in samples). The ammonium data point at 25.34 hours indicates as much as $2.70 \mathrm{~g}$ may have been present in the system at that time, in which case 0.3-0.4 g of ammonia may have been lost (passed through the scrubber and FAVC). The packing in this scrubber was problematic, and it was replaced with a piece of woven wire demister screen. This change may have adversely impacted ammonia recovery by the scrubber.

While some ammonia may have passed through the ammonia scrubber, only $0.01 \mathrm{~g}$ was found in the FAVC condensate, so a more likely explanation is that there was some accumulation and/or propagation of analytical and round-off errors leading to the lack of closure on the SRAT balance. The lab-scale ammonia scrubber appeared to perform adequately if it actually recovered 0.72 of $0.73 \mathrm{~g}$ of ammonia vapor that passed through it (based on the relatively small amount in the FAVC condensate).

IC data indicate a minimum of a $9.2 \mathrm{~g}$ loss of nitrate, or at least 0.15 moles, versus perhaps as much as $2.7 \mathrm{~g}$ or more of ammonium ion formation as of about 25 hours after formic acid, or also at least 0.15 moles made. These two values indicate that the two sets of potentially interrelated data are internally consistent (moles nitrate lost should equal or exceed moles ammonium ion made). The nitrate loss neglects nitrite converted to nitrate (which can be taken as $100 \%$ lost in addition to the $9.2 \mathrm{~g}$ above).

Based on what was happening during SME cycle canister condensate collection (see 4 below), it is virtually certain that ammonia vapor was going into the SRAT off-gas in the latter stages of the SRAT cycle at a higher rate than what accumulated in the ammonia scrubber liquid. The difference in rate off-gassed from SRAT versus rate collected by the scrubber was being recycled to the SRAT vessel in the reflux stream. If not for that process, there may have been very little ammonium ion left in the SRAT product slurry after 10-12 hours of boiling at $\mathrm{pH}$ values that did not favor retaining the dissolved ammonium ion.

4. Following sampling that reduced the slurry mass by $12 \%$, the SME cycle began with a series of five identical water additions and concentrations back to constant slurry mass 
(canister decons). The $\mathrm{pH}$ continued to rise. Ammonium ion was found in all five of the dewater condensates:

Table 22. Decon dewater condensate ammonium

\begin{tabular}{|l|c|}
\hline Canister Decon period & Grams ammonium ion \\
\hline First dewater & 0.71 \\
\hline Second dewater & 0.47 \\
\hline Third dewater & 0.43 \\
\hline Fourth dewater & 0.33 \\
\hline Fifth dewater & 0.19 \\
\hline
\end{tabular}

The mass of ammonium ion collected in the canister decon condensates totaled $2.13 \mathrm{~g}$, or $54 \%$ more than was present in the slurry at the start of the SME $(1.38 \mathrm{~g})$. This difference indicates that ammonium ion formation was on-going during the SME cycle (as does the $8 \%$ nitrate loss during the SME).

The $\mathrm{pH}$ of the SME slurry fluctuated around 7 during the second and third SME canister dewaterings. It is clear that the amount of ammonium ion collected in each condensate was decreasing with time. The implication is that less new ammonium ion was being formed per unit time than was being stripped to the off-gas system. Figure 18 gives the SME cycle data analogous to Figure 16 for excess in $2 \mathrm{O}_{2}+\mathrm{CO}_{2}-\mathrm{H}_{2}$ and $\mathrm{pH}$. The SRAT cycle integration baseline from Figure 16 was rescaled by the ratio of change in air purge flowrate and plotted without any further adjustment. The $0.0004 \mathrm{~mole} / \mathrm{min}$ divisions on the $2 \mathrm{O}_{2}+\mathrm{CO}_{2}-\mathrm{H}_{2}$-axis are the same as those in the SRAT figure.

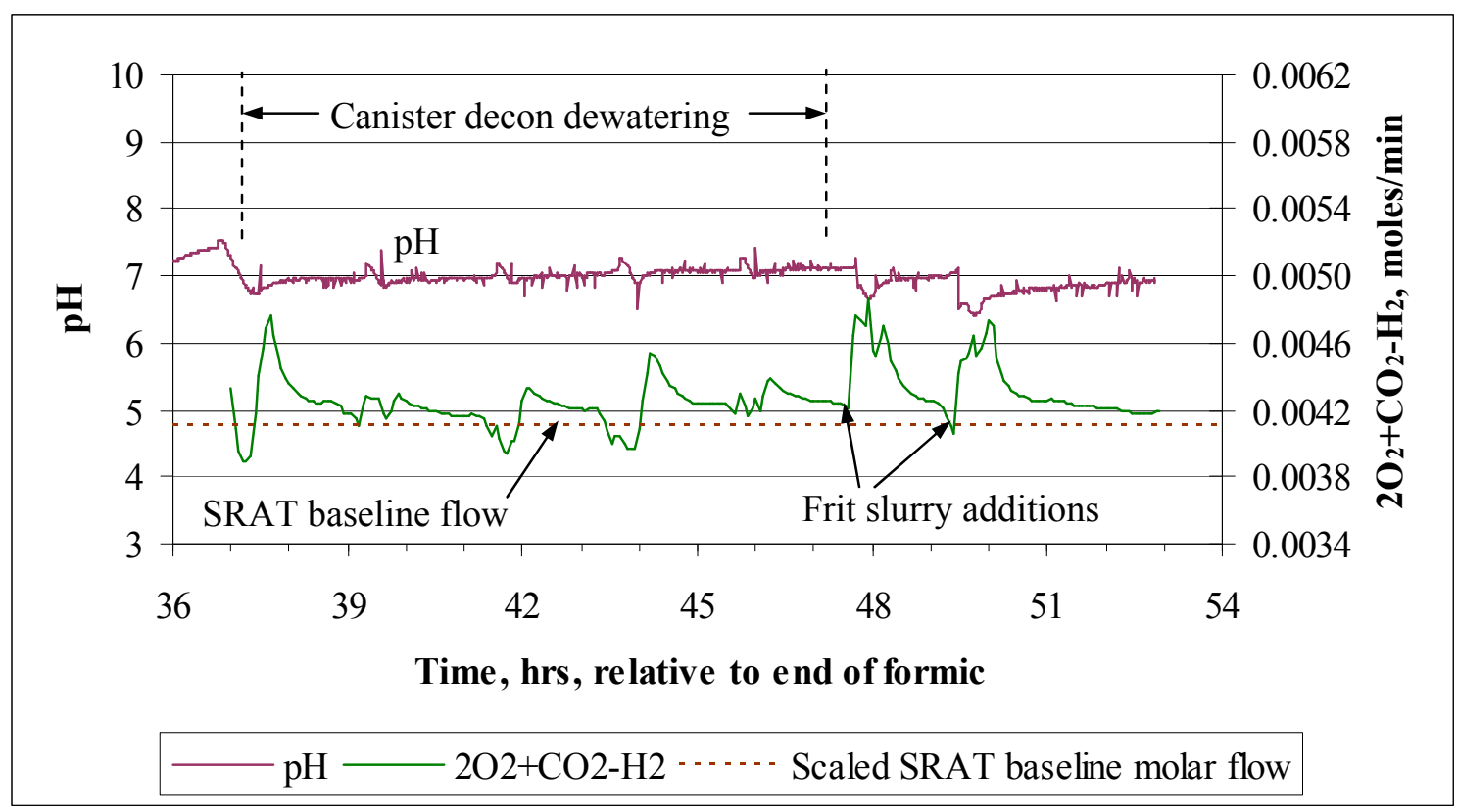

Figure 18. SB6-22 SME cycle $\mathrm{pH}$ and off-gas analysis

There was some positive activity in the off-gas molar flow group during the SME cycle, though it appeared to diminish during canister decon dewatering. The period from 38-47 hours after formic acid addition does not appear to have had very much ammonium ion formation compared 
to comparable 9 hour periods in the latter half of the SRAT cycle. The on-off nature of boiling in the SME cycle tends to complicate this analysis (many boil-up rate changes that trigger off-gas flow and composition upsets). There were two more obvious surges in excess $\mathrm{CO}_{2}$ following each of the frit-formic acid slurry additions. The slurry $\mathrm{pH}$ also dipped back below 7 from the formic acid in the frit slurries. If the catalyst(s) was still active, then ammonium ion formation may have increased in rate somewhat near the end of the SME cycle.

The two frit slurry dewatering condensates were not analyzed for ammonium ion, nor was the SME product. The ammonia scrubber, however, was analyzed, and an additional $0.09 \mathrm{~g}$ of ammonium ion was collected during the entire SME cycle versus $0.72 \mathrm{~g}$ in the SRAT. The total SRAT/SME ammonium ion production that was accounted for through sampling was $3.04 \mathrm{~g}$ or 0.168 moles. Nitrate added as acid, sludge, and trim chemicals totaled 1.335 moles, and an additional 0.307 moles was present at the end of formic acid addition due to nitrite destruction according to the sample results. Therefore, just over $10 \%$ of the available nitrate following nitrite destruction was converted to ammonium ion (depending on what was in the final frit condensates and SME product).

In just the SRAT cycle, $9.4 \%$ of the nitrate from acid, sludge, and trim chemicals was converted to ammonium (neglecting nitrite converted to nitrate for consistency with earlier reports). This conversion was less than in the $150 \%$ acid runs from the Phase II flowsheet study and SB6 qualification simulant study. In the Phase II flowsheet study run at $150 \%$ stoichiometry, at least $20 \%$ of the initial nitrate was converted to ammonium. ${ }^{14}$ In the qualification study run at $150 \%$ stoichiometry, at least $15 \%$ of the initial nitrate was converted to ammonium. ${ }^{15}$ These earlier tests did not have ammonia scrubbers. Although ammonia was absorbed by the FAVC condensate in both cases, it is not clear how this would compare to the performance of the ammonia scrubber in the Phase III work in terms of ammonia recovery efficiency. Consequently, the results for the two earlier studies may more truly be lower bounds rather than actual values for the amount of ammonium ion formation.

Mercury and noble metal concentrations were both lower in Phase III than the two earlier studies. Presumably one or both of these was responsible for the reduced ammonium ion formation. The limited SB6 data do not permit choosing between them as the single most likely explanation for the decrease in ammonium ion formation in Phase III. Going outside of SB6 studies, however, it becomes apparent that high noble metal runs have not generally led to significant ammonium ion formation when mercury concentrations were lower than in SB6. Therefore, mercury (or an amalgam of $\mathrm{Hg}$ ) is the presumed driver for ammonium ion formation.

Data from SB6-23 at nominal acid stoichiometry were developed along similar lines to the data from SB6-22, the high acid run, in Figure 19. The ammonium ion detection limit was $10 \mathrm{mg} / \mathrm{kg}$, or $1 * 10 \mathrm{mg} / \mathrm{kg}$ on the graph. 


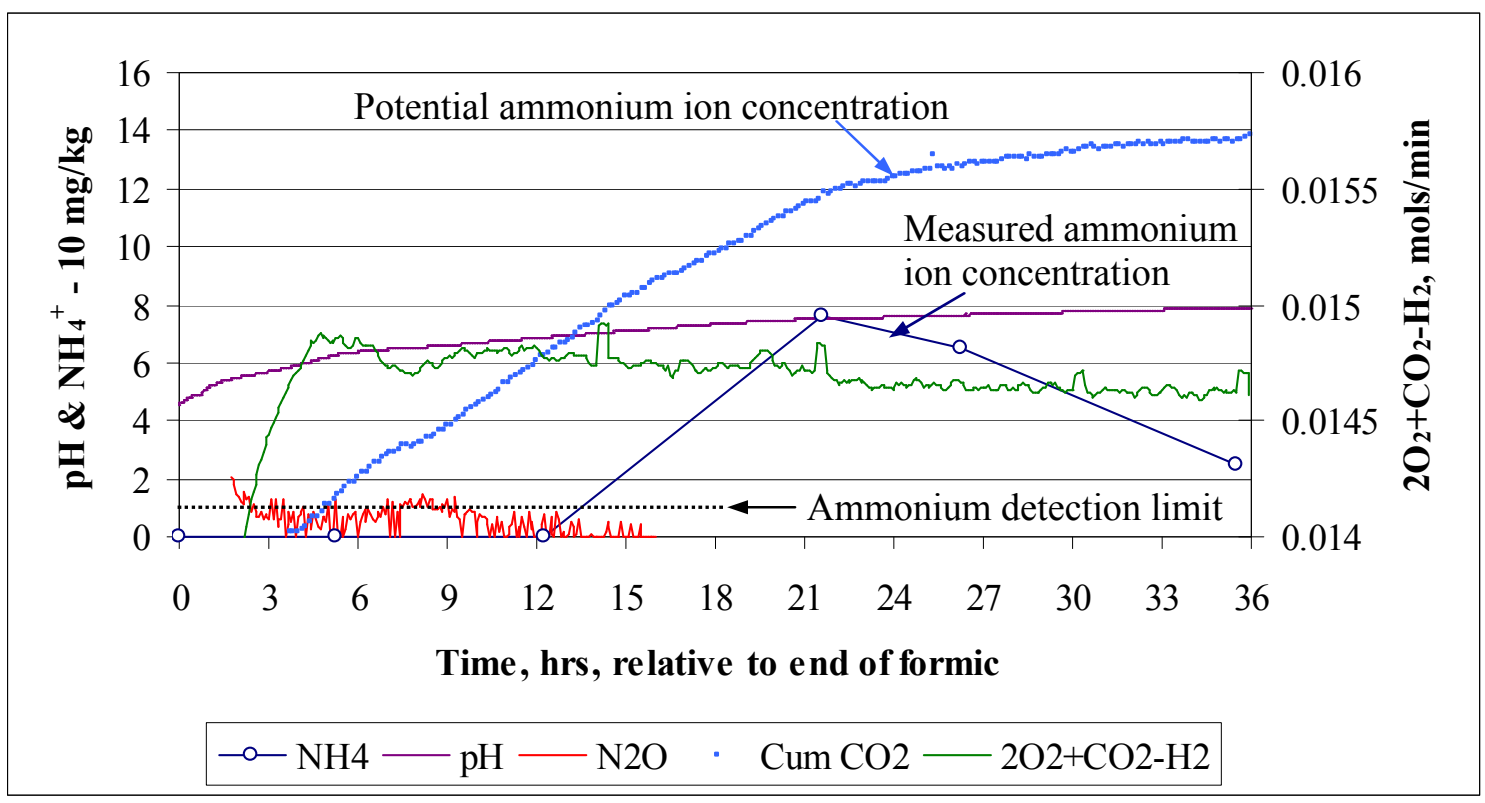

Figure 19. SB6-23 SRAT timeline for nitrate consumption/ammonium formation

The period of $\mathrm{N}_{2} \mathrm{O}$ formation 5-10 hours after formic acid addition ended sooner than in SB6-22, but the $\mathrm{pH}$ rose faster in SB6-23. Ammonium ion was just barely detectable at 12.1 hours after formic acid in the SRAT slurry sample, but the amount could not be quantified (it was a shoulder on the sodium peak rather than a distinct peak). The $\mathrm{pH}$ was postulated to control nitrite ion desorption from the catalyst in the SB6-22 discussion, and the SB6-23 data are consistent with this hypothesis. Excess $\mathrm{CO}_{2}$ production started before ammonium ion was detected, but this is also consistent with the series of reactions and intermediates and the data from SB6-22. The ammonia scrubber had only collected $0.026 \mathrm{~g}$ of ammonium ion at 26 hours after formic acid.

Ammonium ion concentration rose to only $7 \%$ of the maximum concentration seen in SB6-22. The concentration was falling for at least 14 hours at the end of the SRAT versus the last 9 hours in SB6-22. The earlier start of net loss of ammonium from the SRAT-SRAT condenser-MWWT group in SB6-23 was probably a result of the higher slurry $\mathrm{pH}$ values. (Although ammonium ion is probably being refluxed back into the SRAT slurry, vapor-liquid equilibrium considerations probably do not allow the ammonium to remain at as high a concentration in the slurry supernate as $\mathrm{pH}$ goes up.)

Less than detectable amounts of ammonium ion were found in the FAVC condensate following the SRAT cycle. The ammonia scrubber collected $1.05 \mathrm{~g}$ of ammonium ion during the SRAT. The ammonium ion lost from the SRAT slurry from 21 to 35 hours corresponds to $0.12 \mathrm{~g}$. The SRAT product slurry contained $0.06 \mathrm{~g}$ of ammonium ion. The data indicate that the SRATSRAT condenser-MWWT group lost a fairly high fraction of the ammonia vapor if 1.05 of $1.11 \mathrm{~g}$, or $95 \%$, of the ammonium produced made it to the scrubber.

The SME cycle saw significant liberation of ammonia vapor from the SRAT into the dewater condensates similar to what occurred in SB6-22. (The two condensates following the two frit slurry additions were composited into a single sample.) 
SRNL-STI-2010-00212

Revision 0

Table 23. SB6-23 SME condensate ammonium

\begin{tabular}{|l|c|}
\hline Canister Decon period & Grams ammonium ion \\
\hline First dewater & 0.28 \\
\hline Second dewater & 0.09 \\
\hline Third dewater & 0.08 \\
\hline Fourth dewater & 0.07 \\
\hline Fifth dewater & 0.06 \\
\hline Composite frit dewater & 0.01 \\
\hline
\end{tabular}

Note that more ammonium ion was captured in the first SME dewater than was present in the SRAT product slurry. This indicates that ammonium ion formation continued into the SME cycle as in SB6-22. The quantity of ammonium ion collected in the other condensates after the first canister dewatering condensate totaled just $0.31 \mathrm{~g}$, or only slightly more than in the first dewater. No surge was seen in ammonium ion from the two frit-formic acid additions in the frit dewater condensate.

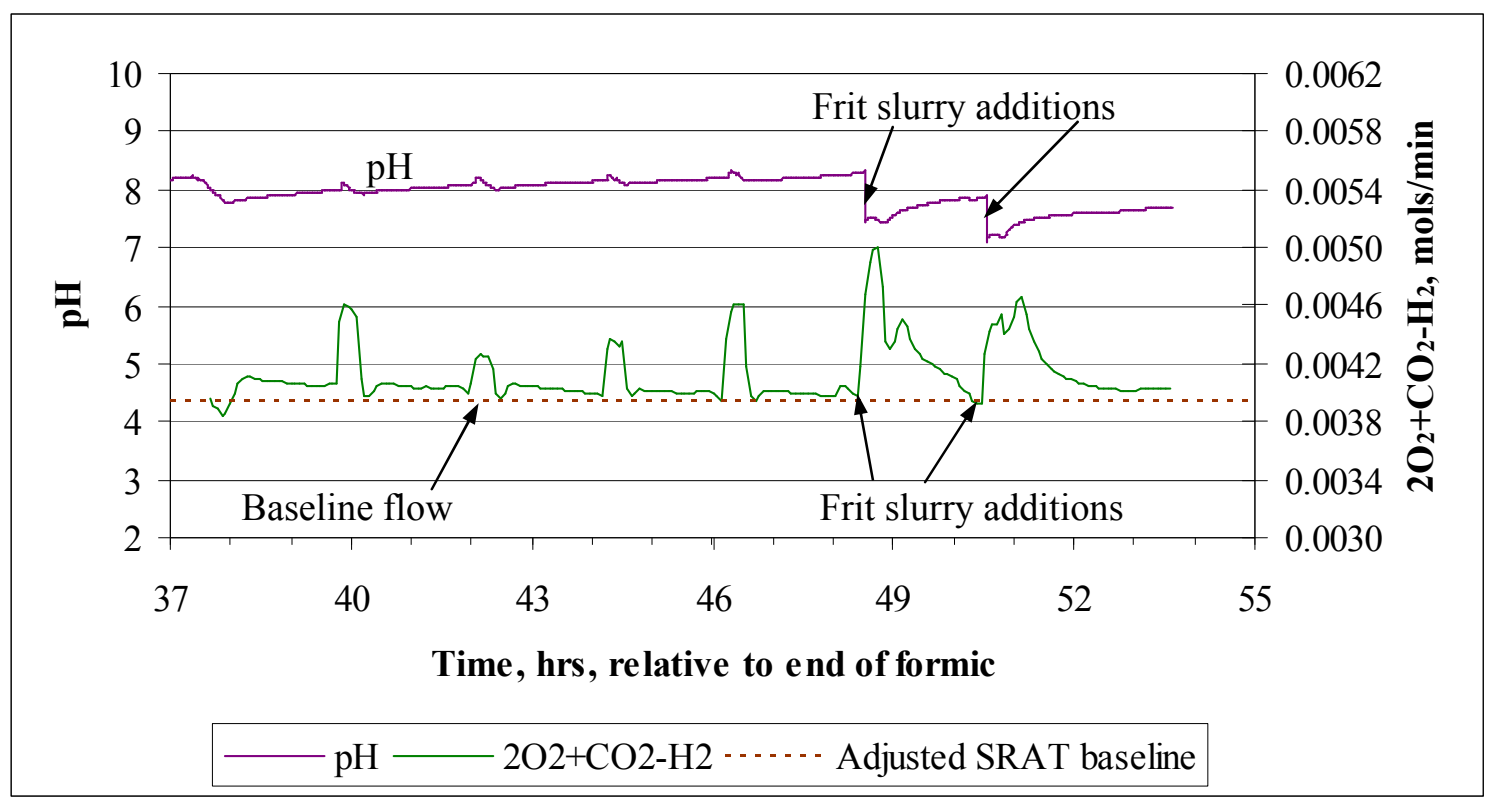

Figure 20. SB6-23 SME cycle pH and off-gas analysis

The two frit-formic acid slurries led to surges in excess $\mathrm{CO}_{2}$ production, but the $\mathrm{pH}$ stayed above 7 in this run, whereas in SB6-22 it dipped back below 7 following the frit slurry additions. As mentioned for SB6-22, the numerical analysis of the SME data is complicated by the on-off nature of boiling, and the impact this has on the time dependent concentrations in the gas hold-up volumes of the off-gas equipment.

The results of the Phase III flowsheet analysis of ammonium ion formation indicate that more attention should be given to SME cycle ammonium ion chemistry than was given in this study. More SME cycle slurry samples should be taken, and more intermediate checks should be made on the contents in the ammonia scrubber reservoir. At this point, one main issue is the form of the catalyst producing the ammonium ion. It may not be homogeneously dispersed like the $\mathrm{Rh}$ and $\mathrm{Ru}$ that produce hydrogen. If so, then data from the lab-scale tests will scale up to DWPF, 
but, if not, then the data do not scale linearly by volume of starting sludge. The observation of a mercury rich amalgam in SB6-22 that had trapped much of the available Rh and Pd would seem to narrow down the possible catalysts for ammonium ion formation to either $\mathrm{Ru}$ or the mercury amalgam. The lower ammonium ion levels seen in Phase III would probably have a minimal impact on the DWPF melter and glass properties.

\subsection{ARP/MCU Test Results from SB6-24}

SB6-24 tested the impact of ARP and MCU additions on SB6 processing with the current DWPF flow sheet. Acid stoichiometry was targeted to match SB6-23, the nominal flowsheet case, at $113 \%$ of the Koopman minimum acid equation (120\% of the DWPF equation). Post-run analytical results obtained from the SRAT receipt sample following ARP addition and concentration indicate that the stoichiometry was $111.8 \%$ Koopman or $118.4 \%$ DWPF, or slightly lower than targeted.

An ARP simulant was used that consisted of MST plus entrained sludge solids based on the ABC simulant used in the hydrogen and beaded frit programs. The same ARP simulant was used for the ARP/MCU flowsheet demonstration with SB5 simulant. ${ }^{13}$ The volume of ARP added during boiling prior to acid addition was 7/6 the starting SB6-G simulant volume. The ARP simulant was $4.7 \mathrm{wt} \%$ in total solids and $2.22 \mathrm{wt} \%$ in insoluble solids. Dewatering during the ARP addition brought the effective total solids content up to the $17.75 \mathrm{wt} \%$ of the SB6-G sludge. This required removing about $68 \%$ of the ARP slurry mass during dewatering. Design-basis ARP solids are at most $50 \%$ entrained sludge with the balance being MST. Noble metals and mercury were trimmed based on the entrained sludge portion only and used the same SB6-G target concentrations as in SB6-21 to 23. The MST solids are essentially free of mercury and noble metals. Consequently, SB6-24 had lower concentrations of mercury and noble metals at the start of acid addition than SB6-21 to 23.

The MCU simulant was made up of $0.033 \mathrm{M}$ nitric acid without any entrained organic species. Credit was taken for the small amount of acid in the MCU stream when determining how much nitric and formic acid to add. MCU addition started immediately after the normal SRAT dewatering following acid addition. MCU was added at the lab-scale equivalent of $5,000 \mathrm{lb} / \mathrm{hr}$ which was also the lab-scale boil-up rate during the addition period. The volume of MCU added was equivalent to $8 / 6$ of the starting SB6-G simulant volume. MCU addition took a little over ten hours. The 3.5 hours of SRAT dewatering plus 10.4 hours of MCU dewatering were subtracted from the total projected boiling time requirement of 35 hours to give 21.1 hours of additional reflux time to complete steam stripping of the mercury.

The SME cycle was limited to two frit-formic acid slurry additions plus associated dewaterings. The five canister decon slurry additions and dewaterings were not included. This strategy is believed to be conservative for hydrogen generation. The extra time spent on ARP addition and dewatering at the beginning of SB6-24 was off-set by deleting the canister dewaterings so that SB6-24 could be completed in essentially the same overall time as SB6-23.

A comparison of SRAT/SME bulk slurry mercury removal between SB6-24 and SB6-23 is given in Figure 17. MCU addition brought in $9 \%$ of the total nitrate in the SRAT cycle, so the predicted melter feed redox value was shifting toward more oxidizing as the MCU was being added. 


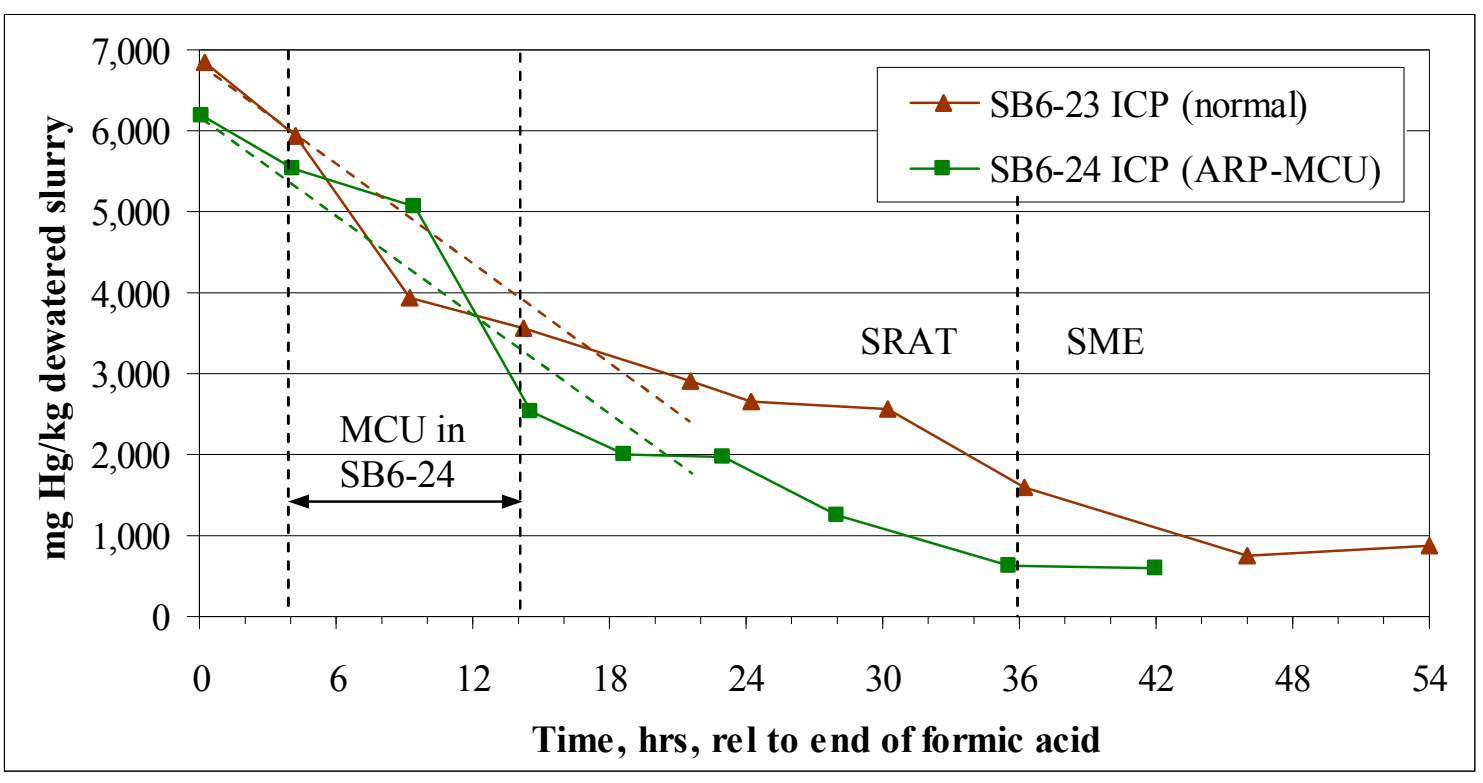

Figure 21. Change in slurry Hg concentration during SRAT

The run with ARP/MCU had 90\% the SRAT receipt mercury concentration of SB6-23. SB6-24 was lower than SB6-23 in mercury concentrations except at one point in the middle of MCU addition. It remained lower through the remainder of the SRAT and SME cycle. The average slopes were comparable for about the first 18 hours after formic acid addition, with SB6-24 running at generally lower mercury concentrations as expected from the lower initial concentration. About 18 hours after formic acid, it appears that ammonium ion formation became a significant reaction. The drop in the rate of mercury stripping may be related to the onset of ammonium ion formation in some fashion. For example, mercury going into amalgam formation may not be exerting its normal vapor pressure.

Mercury material balance closure at $69 \%$ was not as good as in SB6-23 at $82 \%$. No mercury deposits on the agitator were noted, but some discoloration was observed after the SB6-24 equipment was broken down for cleaning. The run had started with brand new impeller blades, so the discoloration definitely occurred during SB6-24 rather than a previous run.

All SRAT slurry samples from SB6-24 had less than the detection limit of ammonium ion (10 $\mathrm{mg} / \mathrm{L}$ ), and no detectable ammonium ion was absorbed into the FAVC condensate from any ammonia in the off-gas system $(<50 \mathrm{ppm}$ reported) passing through the scrubber. Ammonium was being formed, however, as the concentration in the solution refluxing the ammonia scrubber rose to $1,630 \mathrm{mg} / \mathrm{L}$ by the end of the SRAT cycle. The $1.12 \mathrm{~g}$ of ammonium ion collected in the scrubber was very comparable to the $1.05 \mathrm{~g}$ collected in the scrubber during the SRAT cycle in SB6-23 (120\% acid). SB6-22 also had $0.06 \mathrm{~g}$ in the SRAT product, while the ARP/MCU SRAT product had $<0.02 \mathrm{~g}$. The $\mathrm{pH}$ profiles in Appendix A show that the ARP/MCU run was at higher $\mathrm{pH}$ values than SB6-23 during the last half of reflux in the SRAT cycle. The SRAT product sample $\mathrm{pH}$ at room temperature given earlier was 10.21 for the ARP/MCU run versus 9.28 for SB6-23. These results are consistent with the lower SRAT product ammonium ion result for SB6-24.

The rheological properties of SB6-24 samples were better (less viscous) than those of SB6-23. SRAT and SME products from SB6-24 were at higher solids concentrations than those from SB6- 
23 yet had lower yield stresses. Further details are given in Section 3.6, and the raw flow curve data are given in Appendix A.

The incorporation of ARP/MCU into SB6-G at approximately $120 \%$ acid stoichiometry (DWPF) had a mild impact on hydrogen generation as seen in Figure 18.

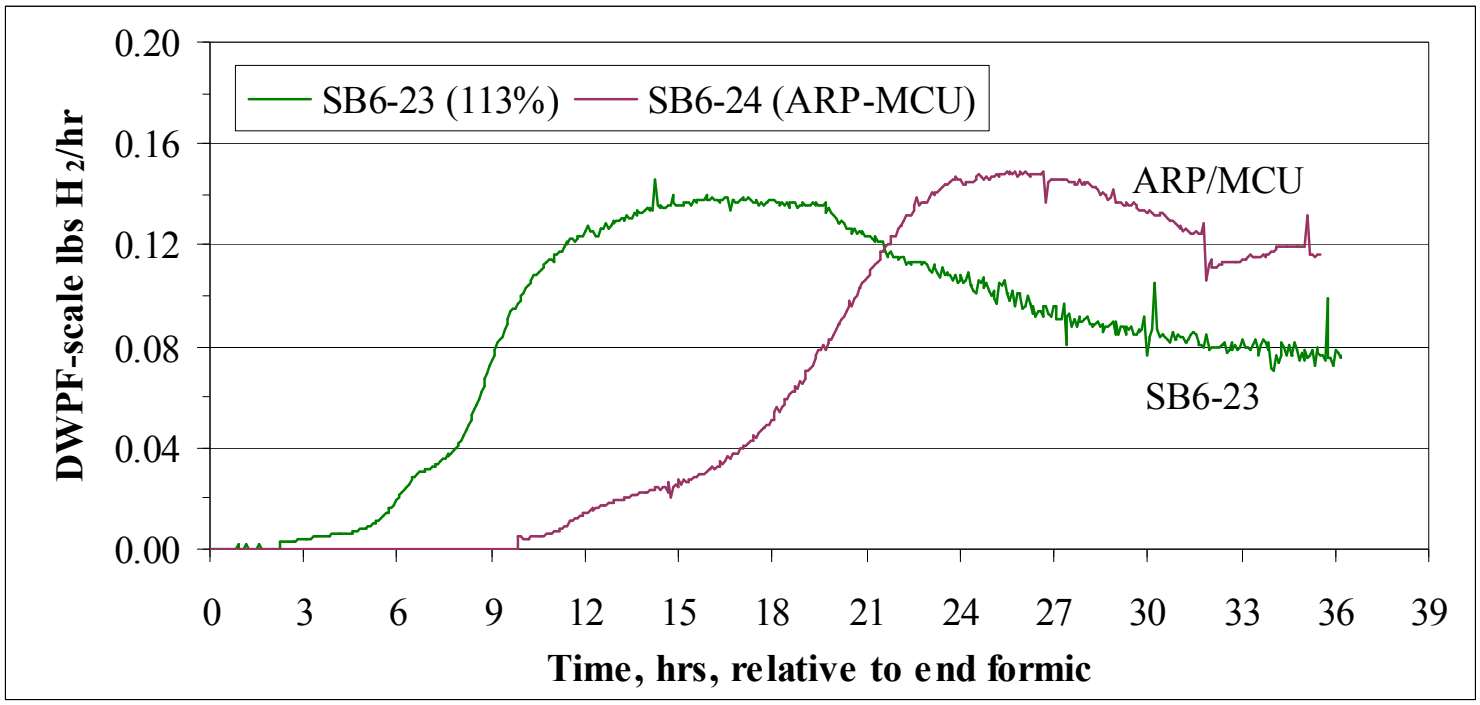

Figure 22. Impact of ARP/MCU on SRAT hydrogen generation

The impact of ARP/MCU on the maximum hydrogen generation rate was insignificant, but the peak came almost twelve hours later in the run with ARP/MCU. It was almost as if the process of hydrogen generation waited until most of the extra acid in the MCU had been combined with the SRAT slurry before it got underway. $\mathrm{N}_{2} \mathrm{O}$ destruction was on-going from the end of acid addition until 19.4 hours after formic acid addition, so nitrite ion was probably present at low concentrations when hydrogen generation started at about 9.5 hours after formic.

There were some minor differences in the profile of $\mathrm{CO}_{2}$ evolution during acid addition in SB624 compared to SB6-23. These were most pronounced around the period of nitrite destruction and $\mathrm{Mn}$ reduction in the last hour of formic acid addition and first hour after formic acid addition. 
SRNL-STI-2010-00212

Revision 0

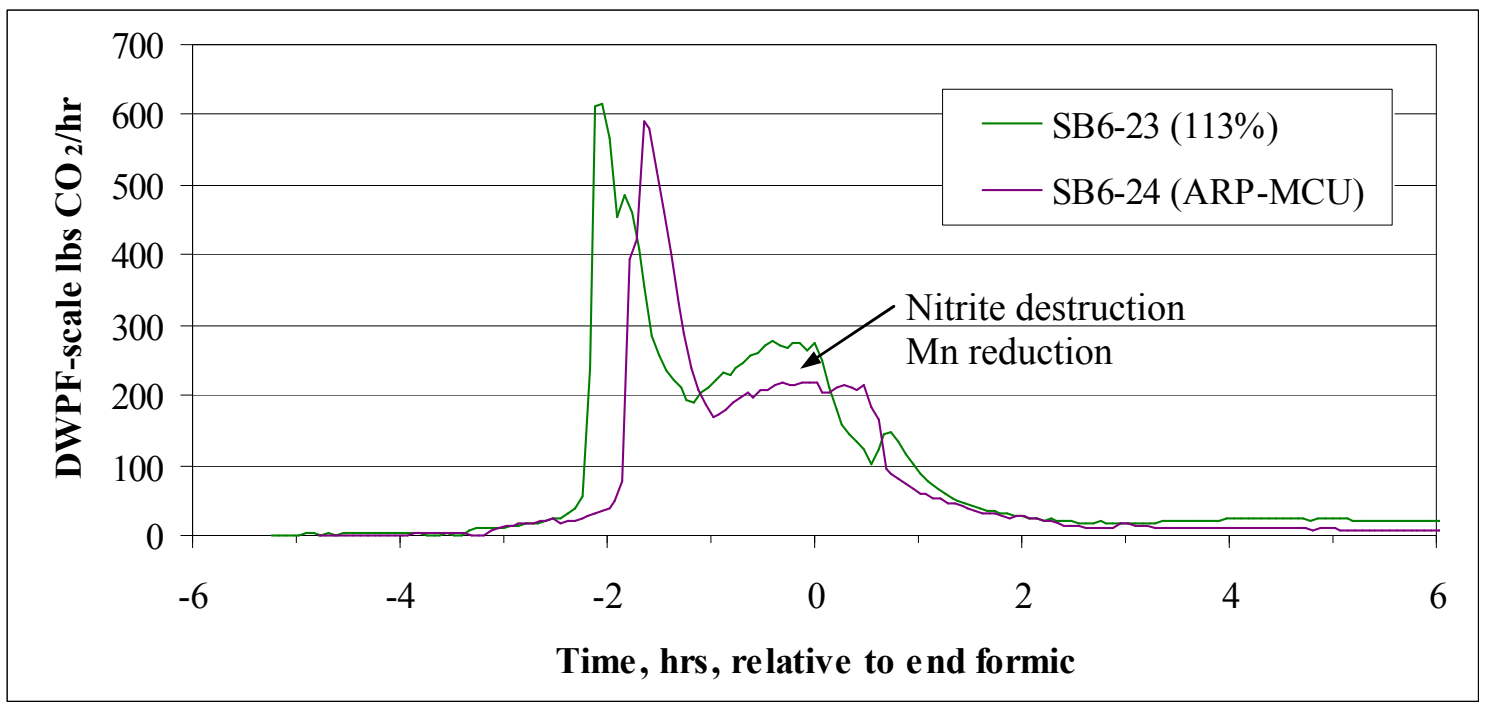

Figure 23. Impact of ARP on $\mathrm{CO}_{2}$ generation during acid addition

The profile of $\mathrm{CO}_{2}$ generation after acid addition was also different, Figure 20.

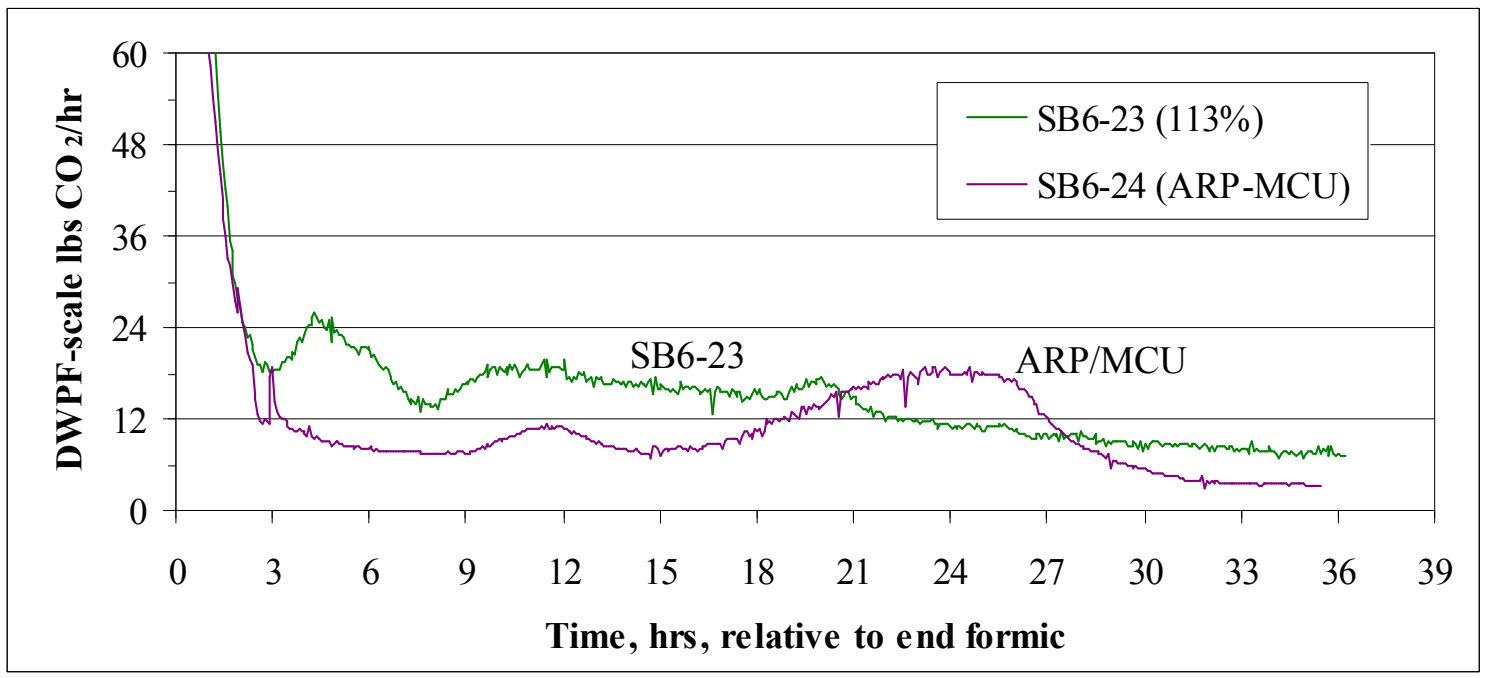

Figure 24. Impact of $\mathrm{ARP} / \mathrm{MCU}$ on $\mathrm{CO}_{2}$ generation during boiling

The carbon dioxide production level in SB6-24 was generally lower than in SB6-23 except during the period of higher hydrogen generation in SB6-24 after about 21 hours from the end of formic acid addition. The peak in $\mathrm{CO}_{2}$ generation rate about 24 hours after formic acid fell in the period where the ammonia scrubber collected the majority of the ammonium ion in SB6-24. Total $\mathrm{CO}_{2}$ mass in the SB6-24 SRAT cycle integrated to $61.4 \mathrm{~g}$ versus $79.2 \mathrm{~g}$ in SB6-23. The lower value is consistent with a general delay in catalytic attack on formate in SB6-24.

No major differences were seen in the generation of $\mathrm{N}_{2} \mathrm{O}$, Figure 21, but there were some minor differences. 
SRNL-STI-2010-00212

Revision 0

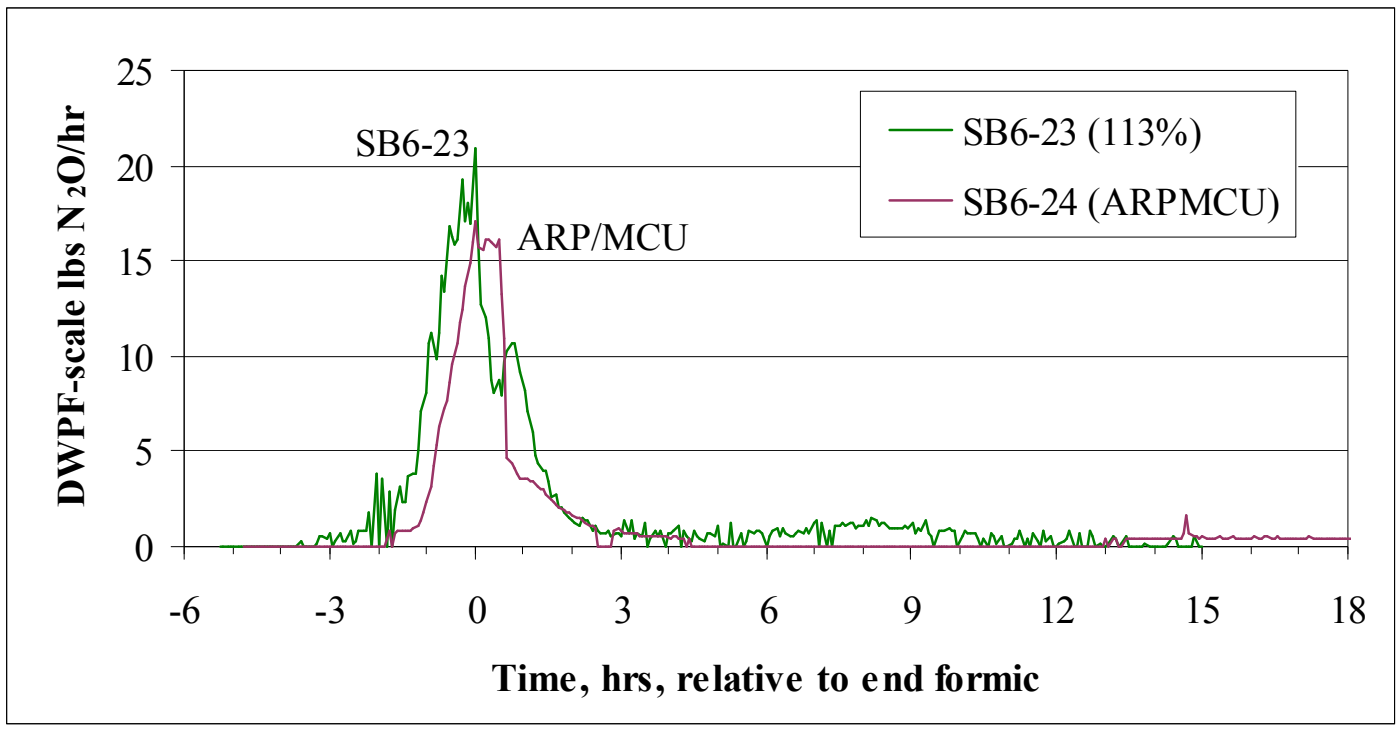

Figure 25. Impact of ARP/MCU on nitrous oxide generation

Mercury has been found to promote $\mathrm{NO}$ production at the expense of $\mathrm{N}_{2} \mathrm{O}$ production, so decreasing mercury generally leads to an increase in $\mathrm{N}_{2} \mathrm{O}$ production. The $10 \%$ reduction in mercury added to SB6-24 probably would have led to a detectable increase in the maximum $\mathrm{N}_{2} \mathrm{O}$ production rate, but the amount of nitrite present initially in SB6-24 was only $84 \%$ as high as in SB6-23. Because there was less initial nitrite, both $\mathrm{NO}$ (and $\mathrm{NO}_{2}$ ) production and $\mathrm{N}_{2} \mathrm{O}$ production (1.6 versus $2.3 \mathrm{~g} \mathrm{~N}_{2} \mathrm{O}$ ) were lower in SB6-24 (41 versus $48 \mathrm{~g}$ was the calculated $\mathrm{NO}_{2}$ difference). SB6-23 also appeared to be producing more $\mathrm{N}_{2} \mathrm{O}$ than the ARP/MCU run during boiling after formic acid addition particularly from 5 to 13 hours after formic acid addition (also the period of MCU addition in the ARP/MCU run). This $\mathrm{N}_{2} \mathrm{O}$ in SB6-23 may have been associated with the reaction sequence that produces ammonium ion. SB6-24 resumed a low level of $\mathrm{N}_{2} \mathrm{O}$ formation about 13 hours after formic acid, which also may have been a precursor to ammonium ion formation.

SME cycle hydrogen generation rate data are shown for SB6-24. The two frit slurry additions are aligned with the two frit slurry additions from SB6-23. As discussed earlier, SB6-24 did not have the five canister water additions. 


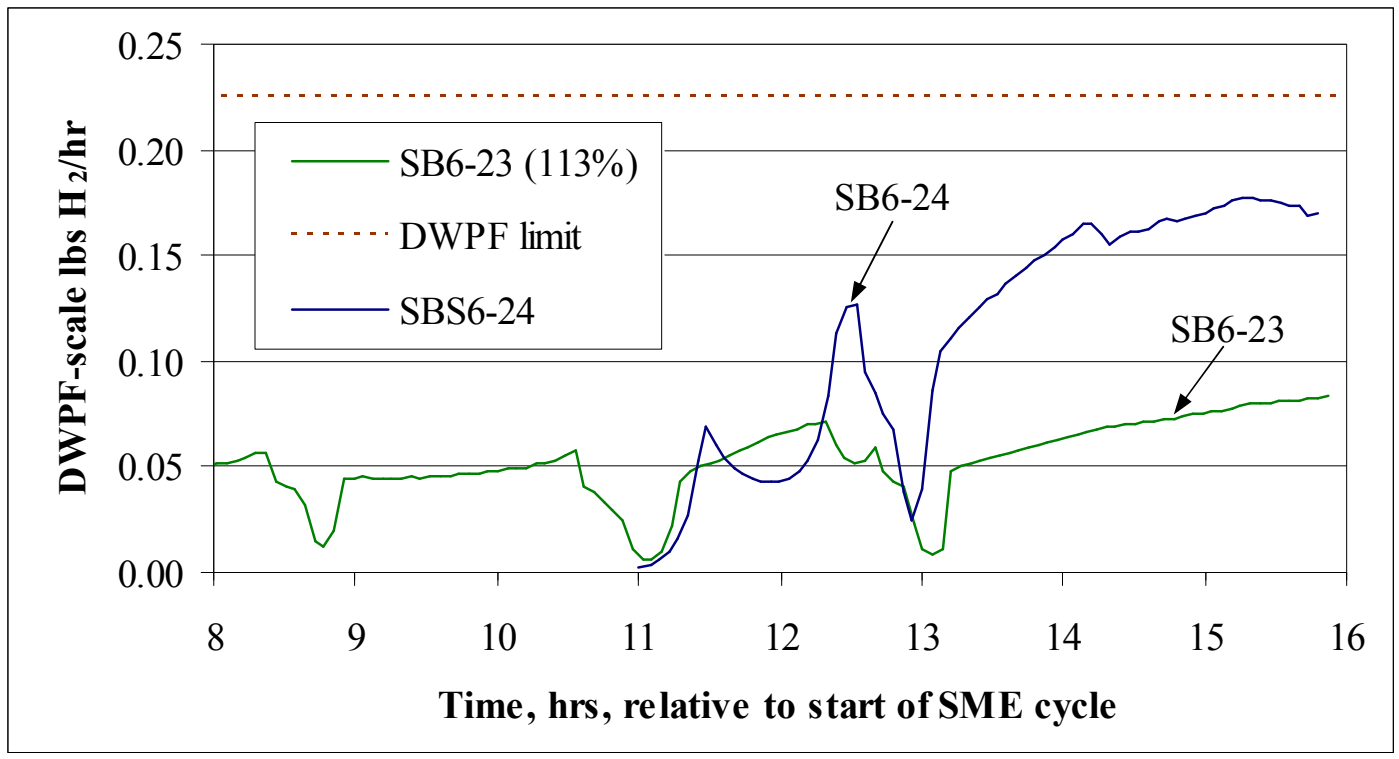

Figure 26. SME cycle hydrogen with and without ARP/MCU

The effect of the first frit addition was not too dissimilar to SB6-23, but the cumulative impact of two frit slurry additions appeared to lead to more excess formic acid. Another issue was that water losses were higher in SB6-24 than the other three runs (which ended in the 50-51.5\% range). The SME cycle ended at $55 \mathrm{wt} \%$ total solids versus a target of $48 \%$. Consequently, the acid and noble metals were more concentrated in the final SME slurry than they should have been, and more concentrated than SB6-23, and this led to increased catalytic hydrogen generation over what should have occurred if the water losses had not occurred.

\subsection{Rheology Data}

Flow curves for samples of the four SRAT and four SME product slurries were obtained using the Haake RS600 rheometer and standard DWPF simulant rheology protocols. ${ }^{16}$ The up flow curves and down flow curves were both fit to the Bingham plastic rheological model equation to get a yield stress (intercept) and a consistency (slope) for the flow curve. The eight sets of duplicate flow curves are given in Appendix A. The summary of the flow curve analysis is given below. Rheological properties in Table 21 and Table 22 are averages of two measurements.

Table 24. SRAT product rheology summary

\begin{tabular}{|l|c|c|c|c|}
\hline & SB6-21 & SB6-22 & SB6-23 & SB6-24 \\
\hline $\mathrm{Wt} \%$ total solids & 27.2 & 25.3 & 27.0 & 29.2 \\
\hline $\mathrm{Wt} \%$ insoluble solids & 16.0 & 14.0 & 14.2 & 16.0 \\
\hline $\mathrm{pH}$ & 9.47 & 8.45 & 9.28 & 10.21 \\
\hline Slurry density, g/mL & 1.191 & 1.188 & 1.266 & 1.222 \\
\hline Up yield stress, $\mathrm{Pa}$ & 6.5 & 4.7 & 4.5 & 3.2 \\
\hline Up consistency, cP & 15.5 & 4.7 & 12.0 & 12.3 \\
\hline Down yield stress, $\mathrm{Pa}$ & 5.5 & 2.6 & 4.2 & 3.1 \\
\hline Down consistency, cP & 16.1 & 7.8 & 12.8 & 12.5 \\
\hline
\end{tabular}


The SRAT products fell between 32 and 65 dynes $/ \mathrm{cm}^{2}$ for yield stress (3.2-6.5 Pa), which is somewhat higher than the assumed operating range of $15-50$ dynes $/ \mathrm{cm}^{2}$. Consistencies ranged from 4.7-16.1 cP which went slightly above the nominal range of 5-12 cP.

Table 25. SME product rheology summary

\begin{tabular}{|l|c|c|c|c|}
\hline & SB6-21 & SB6-22 & SB6-23 & SB6-24 \\
\hline $\mathrm{Wt} \%$ total solids & 50.3 & 49.9 & 51.5 & 55.0 \\
\hline $\mathrm{Wt} \%$ insoluble solids & 39.8 & 39.2 & 39.4 & 43.7 \\
\hline $\mathrm{pH}$ & 8.70 & 8.23 & 8.91 & 8.65 \\
\hline Slurry density, g/mL & 1.43 & 1.44 & 1.44 & 1.50 \\
\hline Up yield stress, $\mathrm{Pa}$ & 28.4 & 22.2 & 37.9 & 32.2 \\
\hline Up consistency, cP & 48.4 & 39.7 & 52.7 & 62.2 \\
\hline Down yield stress, $\mathrm{Pa}$ & 34.7 & 26.6 & 44.3 & 42.2 \\
\hline Down consistency, cP & 30.2 & 28.1 & 31.1 & 30.2 \\
\hline
\end{tabular}

The SME products had yield stresses from 220-450 dynes $/ \mathrm{cm}^{2}$ (22-45 $\mathrm{Pa}$ ), all of which exceeded the DWPF upper design basis yield stress of 150 dynes $/ \mathrm{cm}^{2}$. Consistencies ranged from $26-63 \mathrm{cP}$, with three exceeding the $40 \mathrm{cP}$ design basis.

Both SRAT and SME product flow curves showed a certain amount of hysterisis, or shifting of the down flow curve data relative to the up flow curve data. The SRAT products generally had a slightly lower yield stress and slightly higher consistency in the down curve data, while the SME products generally had a somewhat higher yield stress and lower consistency in the down curve data. These differences are fairly common in simulant SRAT and SME product rheology data.

\subsection{Foaminess}

Some residual tendency to foam was noted while following a fairly liberal antifoam addition strategy. The nominal case at $120 \%$ stoichiometry, SB6-23, formed and sustained a modest foam layer during reflux. 


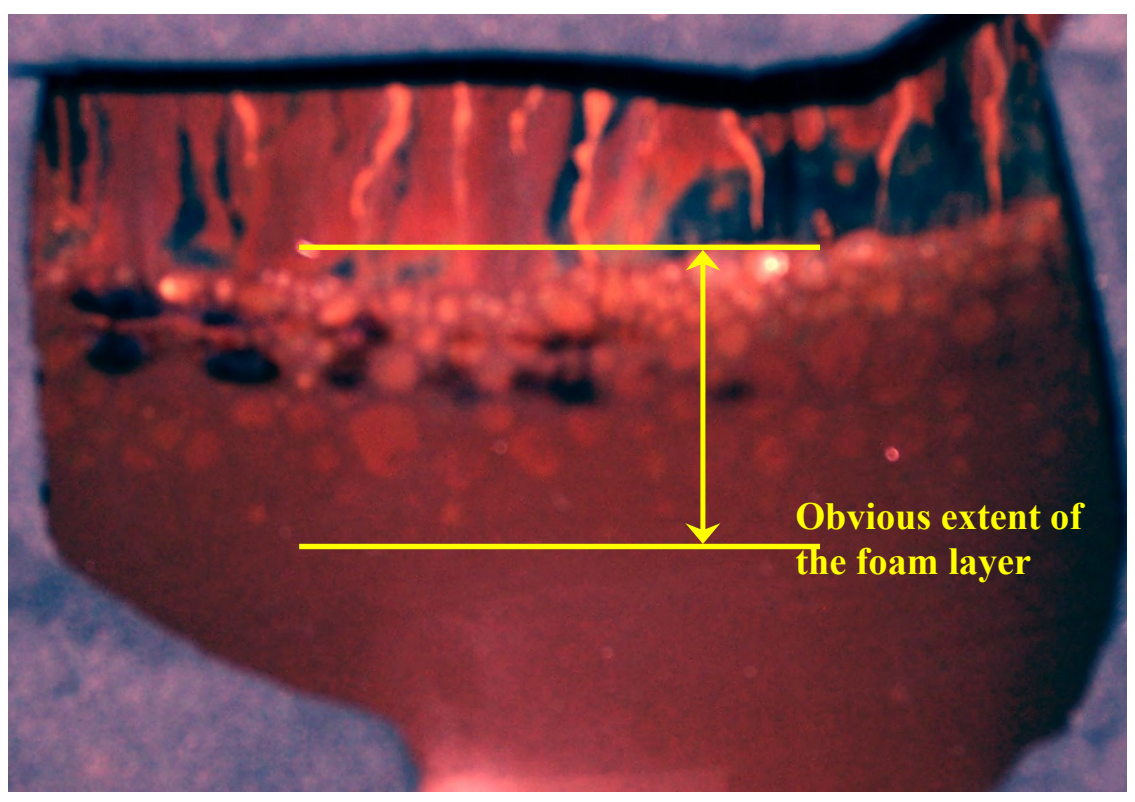

Figure 27. Reflux foaming in SB6-23

The black marks are ink on the outside of the glass SRAT vessel. The view is through an opening in the insulation layer that normally covers the SRAT vessel walls that are out of the heating mantle. The opening is about 2-3 inches high. Generally only a single or double layer of foam bubbles are observed during reflux. The antifoam additions up to this point had been $200 \mathrm{ppm}$ prior to nitric acid, $100 \mathrm{ppm}$ prior to formic acid, and $500 \mathrm{ppm}$ prior to going to boiling.

A second episode of foaming was noted during SB6-24, the ARP/MCU run. The foaming was observed during caustic boiling of the SRAT while adding the ARP slurry, Figure 24. A foam layer was present for most of the ARP addition/dewatering. This layer was somewhat thicker than the SB6-23 reflux foam layer.

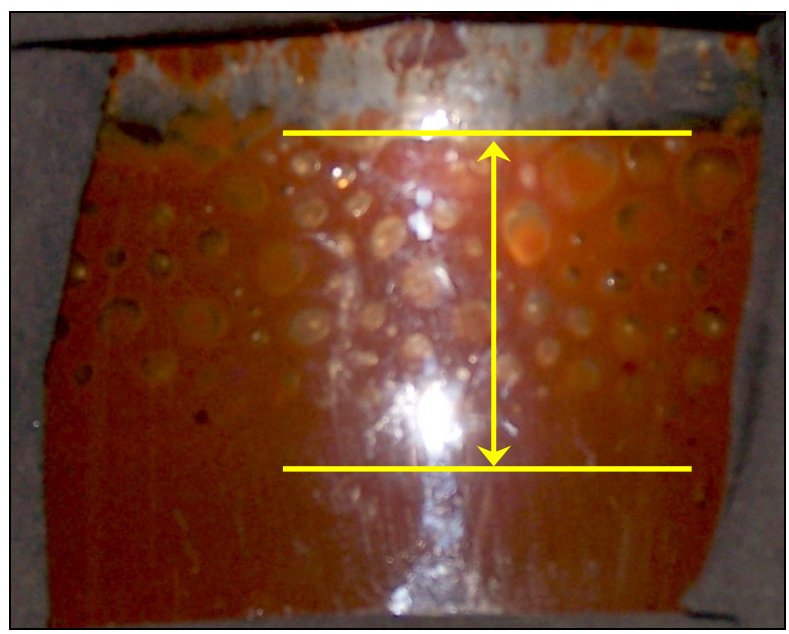

Figure 28. Foaming during caustic boiling with ARP addition

A $200 \mathrm{ppm}$ antifoam addition was made prior to starting caustic boiling. The foam layer was much thicker than normally seen during caustic boiling of simulant, but it showed no tendency to 
increase in thickness over time. No additional antifoam was added during the 6.5 hour period of ARP addition. It is presently unknown whether something in the SB6-G sludge or something in the ARP solids was stabilizing the foam layer.

\subsection{Conclusions}

Phase III simulant flowsheet testing was completed using the latest composition estimates for SB6/Tank 40 feed to DWPF. The goals of the testing were to determine reasonable operating conditions and assumptions for the startup of SB6 processing in the DWPF. Testing covered the region from $102-159 \%$ of the current DWPF acid equation (96-150\% of the Koopman minimum acid equation).

Nitrite ion concentration was reduced to $90 \mathrm{mg} / \mathrm{kg}$ in the SRAT product of the $102 \%$ acid run. The $159 \%$ acid run reached $60 \%$ of the DWPF Sludge Receipt and Adjustment Tank (SRAT) limit of $0.65 \mathrm{lb} \mathrm{H}_{2} / \mathrm{hr}$, and then sporadically exceeded the DWPF Slurry Mix Evaporator (SME) limit of $0.223 \mathrm{lb} \mathrm{H}_{2} / \mathrm{hr}$. Rates as high as $112 \%$ of the SME limit were measured, but higher than targeted $\mathrm{wt} \%$ total solids levels may have been partially responsible for high rates seen. A stoichiometric factor of $120 \%$ met both objectives. A processing window for SB6 exists from $102 \%$ to something approaching $159 \%$. An initial recommendation for SB6 processing is at 115 $120 \%$ of the current DWPF stoichiometric acid equation. The addition of simulated Actinide Removal Process (ARP) and Modular Caustic Side Solvent Extraction Unit (MCU) streams to the SRAT cycle had no apparent impact on the preferred stoichiometric factor.

Hydrogen generation occurred continuously after acid addition in three of the four tests. The three runs at $120 \%, 118.4 \%$ with $\mathrm{ARP} / \mathrm{MCU}$, and $159 \%$ stoichiometry were all still producing around $0.1 \mathrm{lb}$ hydrogen/hr at DWPF scale after 35 hours of boiling in the SRAT. The $120 \%$ acid run reached $23 \%$ of the SRAT limit and $37 \%$ of the SME limit. Conversely, nitrous oxide generation was subdued compared to previous sludge batches, staying below $29 \mathrm{lb} / \mathrm{hr}$ in all four tests or about a fourth as much as in comparable SB4 testing.

Two processing issues, identified during Phase II flowsheet testing and qualification simulant testing, were monitored during Phase III. Mercury material balance closure was impacted by acid stoichiometry, and significant mercury was not accounted for in the high acid run. Observations were made of mercury scale formation in the SRAT condenser and MWWT. A mercury amalgam with $\mathrm{Rh}, \mathrm{Pd}$, and $\mathrm{Cu}$, plus some $\mathrm{Ru}$ and $\mathrm{Ca}$ formed on the impeller at high acid. It contained a significant fraction of the available $\mathrm{Pd}, \mathrm{Cu}$, and $\mathrm{Rh}$. Free (elemental) mercury was found in all of the SME products after air-drying them to solid form.

Significant ammonium ion formation was again observed during the SRAT cycle, and ammonia gas entered the off-gas as the $\mathrm{pH}$ rose during boiling. Much of the activity was during the second half of reflux. Both sample and off-gas data supported this timing for the reaction. Off-gas data supported the proposed overall stoichiometry of ammonium ion formation based on the quantity of $\mathrm{CO}_{2}$ produced as a by-product. Nitrate loss was consistent with ammonium formation in the high acid run (nitrate loss could not be accurately estimated in the other runs). Comparable ammonium ion formation occurred in the ARP/MCU simulation compared to the $120 \%$ acid run. The ammonium was only found in the ammonia scrubber liquid, perhaps due to the higher $\mathrm{pH}$ in the slurry. Ammonia scrubbers were used during the tests to capture the ammonia for material balance purposes. Some ammonia went through the scrubbers without being absorbed and was collected in the FAVC condensate, but the relative ammonium ion masses in the FAVC 
condensates were quite low. The location(s) of the catalyst for ammonium ion formation has not been identified, which has the potential to impact scale-up of the ammonium ion results from labscale to DWPF. The two likeliest catalyst candidates are Ru and the mercury amalgam.

Over $5 \%$ of the slurry mass was lost as fugitive water vapor emissions in each run. This caused the SRAT and SME product slurries to be higher in wt $\%$ total solids than targeted. The higher losses were attributed to a combination of the longer cycle times plus the higher SRAT pressures caused by the addition of a packed scrubber to the off-gas system. Consequently, the rheological properties of the SRAT and SME products were toward the more viscous end of the scale. The more concentrated slurries also potentially produced hydrogen at higher rates than if they had been at target solids concentrations.

Two periods of foaminess were noted. Neither required additional antifoam to control the foam growth. A steady foam layer foamed during reflux in the $113 \%$ acid run. It was about an inch thick, but was 2-3 times more volume of bubbles than is typically seen during reflux. A similar foam layer also was seen during caustic boiling the simulant during the ARP addition. Foaminess during caustic boiling with simulants has been relatively rare.

\subsection{Recommendations and Future Work}

It is recommended that DWPF process SB6 at 115-120\% of the current DWPF stoichiometric acid equation value. Should processing issues warrant a higher stoichiometry than DWPF could make incremental increases, e.g. 5\% steps, while monitoring their process for hydrogen. Operating near either of the DWPF SRAT and SME hydrogen limits while processing variable amounts of ARP and MCU might warrant conversion to the Koopman minimum acid equation, which handles soluble acid consumers more appropriately than the current DWPF equation.

A supporting SRAT test with SB6-G simulant at the intermediate acid stoichiometry was performed several weeks after the tests in this report. The SRAT used a lower formic acid addition rate and a lower boil-up rate than the other flowsheet tests. The lower rates are closer to actual DWPF operating practice. A related test using a more viscous (ultrasonicated) version of SB6-G simulant was performed at the same time to evaluate the effects of higher yield stress on processing. The more viscous simulant was about five times closer to the yield stress of the Shielded Cells SB6/Tank 51 qualification sample than the as-made SB6-G simulant. The process of data and sample analysis are underway. Results from these two follow-up study tests will be documented separately.

Further testing of the ammonia scrubbers was performed during the follow-up SB6-G SRAT testing. Both tests experienced problems with column flooding.

The mercury deposits found on the SB6-22 impeller were a substantial fraction of the starting mercury and were also enriched in copper and noble metals. Potentially all of the Pd and Rh may have been in mercury amalgams (assuming there may have been some besides those on the impeller blades, where $50-100 \%$ of these elements were found). The mercury amalgam may be resistant to steam stripping. Further research/analysis of this substance would be needed to determine how much of the mercury material balance closure issues are being driven by its formation. The amalgam is one of the prime candidate catalysts for ammonium ion formation, which could be a source of scale-up issues for ammonium formation and the species that its formation is impacting (nitrate and formate). 
SB6-G simulant had a higher tendency to foam than the majority of prior sludge batch simulants, so antifoam quality and performance could be issues that DWPF needs to track more closely than in the past (assuming the real waste exhibits similar behavior). 
SRNL-STI-2010-00212

Revision 0

\subsection{References}

${ }^{1}$ Bricker, J. M., Sludge Batch 6 Flowsheet Studies, HLW-DWPF-TTR-2008-0043, Rev. 0, Savannah River Site, Aiken, SC 29808 (2008).

${ }^{2}$ Lambert, D. P., Sludge Batch 6 Simulant Flowsheet Studies, SRNL-RP-2008-01341, Rev. 0, Savannah River Site, Aiken, SC 29808 (2009).

${ }^{3}$ Pareizs, J. M., C. J. Bannochie, et al., Sludge Washing and Demonstration of the DWPF Flowsheet in the SRNL Shielded Cells for Sludge Batch 5 Qualification, SRNS-STI-2008-00111, Rev. 0, Savannah River Site, Aiken, SC, 29808 (November 2008).

${ }^{4}$ Koopman, D. C., J. M. Pareizs, et al., Sludge Batch 4 Follow-up Qualification Studies to Evaluate Hydrogen Generation, WSRC-TR-2007-00212, Rev. 0, Savannah River Site, Aiken, SC, 29808 (June 2007).

${ }^{5}$ Pareizs, J. M., D. C. Koopman, et al., Sludge Batch 3 Qualification in the SRTC Shielded Cells, WSRC-TR-2004-00050, Savannah River Site, Aiken, SC, 29808 (May 2004).

${ }^{6}$ Fellinger, T. L., J. M. Pareizs, et al., Confirmation Run of the DWPF SRAT Cycle Using the Sludge-only Flowsheet with Tank 40 Radioactive Sludge and Frit 200 in the Shielded Cells Facility, WSRC-TR-2002-00076, Rev. 0, Savannah River Site, Aiken, SC, 29808 (April 2002).

${ }^{7}$ Newell, J. D., Simulant Development for Sludge Batch 6, SRNL-STI-2010-00219, SRNL, Aiken, SC, 29808 (April 2010).

${ }^{8}$ Pareizs, J. M., J. M. Bricker, M. T. Keefer, and H. B. Shah, Tank 51 SB6 Qualification SRAT Receipt Characterization, SRNL-L3100-2010-00027, Savannah River Site, Aiken, SC, 29808 (March 11, 2010).

${ }^{9}$ Koopman, D.C., A.I. Fernandez, B.R. Pickenheim, Preliminary Evaluations of Two Proposed Stoichiometric Acid Equations, Rev. 0, SRNL-L3100-2009-00146, Savannah River Site, Aiken, SC 29808 (2009).

${ }^{10}$ Marek, J. C. and R. E. Eibling, Calculational Algorithms for Nitric Acid Sludge Adjustment, SRTC-PTD-92-0050, Savannah River Site, Aiken, SC, 29808 (September 1992).

${ }^{11}$ Jantzen, C. M. and M. E. Stone, Role of Manganese Reduction/Oxidation (RedOx) on Foaming and Melt Rate in High Level Waste Melters, WSRC-STI-2006-00066, Savannah River Site, Aiken, SC, 29808 (March 2007).

${ }^{12}$ Koopman, D. C., D. P. Lambert, D. R. Best, and M. J. Barnes, DWPF Simulant CPC Testing in Support of Sludge Batch 4 Qualification, WSRC-STI-2006-00062, Savannah River Site, Aiken, SC, 29808 (October 2006).

${ }^{13}$ Lambert, D. P., et al., Sludge Batch 5 Simulant Flowsheet Studies, SRNS-STI-2008-00024, Savannah River Site, Aiken, SC, 29808 (October 2008).

${ }^{14}$ Koopman, D. C. and D. R. Best, Sludge Batch 6 Phase II Flowsheet Simulations, SRNL-STI2010-00041, Savannah River Site, Aiken, SC, 29808 (February 2010).

${ }^{15}$ Koopman, D. C. and D. R. Best, Sludge Batch 6/Tank 51 Simulant Chemical Process Cell Simulations, SRNL-STI-2010-00173, Savannah River Site, Aiken, SC, 29808 (April 2010).

${ }^{16}$ Koopman, D. C., Rheology Protocols for DWPF Samples, WSRC-RP-2004-00470, Savannah River Site, Aiken, SC, 29808 (October 2004). 
SRNL-STI-2010-00212

Revision 0

Appendix A - Additional Data 
The SRAT product elemental composition is given in Table A-1 on a calcined basis. SB6-G simulant composition is given for comparison. The SB6-24 results reflect the presence of monosodium titanate and entrained generic sludge solids combined with SB6-G simulant.

Table A-1. SRAT product elemental wt \%'s calcined at $1100{ }^{\circ} \mathrm{C}$

\begin{tabular}{|c|c|c|c|c|c|}
\hline & SB6-G & SB6-21 & SB6-22 & SB6-23 & SB6-24 \\
\hline $\mathrm{Al}$ & 13.0 & 13.3 & 13.3 & 13.0 & 11.6 \\
\hline $\mathrm{Ba}$ & 0.13 & 0.14 & 0.14 & 0.13 & 0.12 \\
\hline $\mathrm{Ca}$ & 0.63 & 0.59 & 0.59 & 0.63 & 0.71 \\
\hline $\mathrm{Ce}$ & 0.20 & 0.19 & 0.19 & 0.20 & 0.15 \\
\hline $\mathrm{Cr}$ & 0.17 & 0.18 & 0.18 & 0.16 & 0.14 \\
\hline $\mathrm{Cu}$ & 0.09 & 0.09 & 0.03 & 0.10 & 0.07 \\
\hline $\mathrm{Fe}$ & 20.6 & 19.1 & 19.5 & 18.6 & 16.3 \\
\hline $\mathrm{K}$ & 0.19 & 0.20 & 0.19 & 0.17 & 0.17 \\
\hline $\mathrm{La}$ & 0.10 & 0.10 & 0.10 & 0.10 & 0.08 \\
\hline $\mathrm{Mg}$ & 0.50 & 0.55 & 0.55 & 0.51 & 0.54 \\
\hline $\mathrm{Mn}$ & 6.18 & 5.89 & 5.95 & 5.66 & 4.81 \\
\hline $\mathrm{Na}$ & 17.6 & 18.1 & 18.4 & 17.5 & 19.3 \\
\hline $\mathrm{Ni}$ & 2.8 & 2.7 & 2.7 & 2.6 & 2.1 \\
\hline $\mathrm{P}$ & $<0.1$ & $<0.1$ & $<0.1$ & $<0.1$ & $<0.1$ \\
\hline $\mathrm{Pb}$ & $<0.1$ & $<0.1$ & $<0.1$ & $<0.1$ & $<0.1$ \\
\hline $\mathrm{S}$ & 0.39 & 0.44 & 0.43 & 0.42 & 0.49 \\
\hline $\mathrm{Si}$ & 1.3 & 1.2 & 1.2 & 1.3 & 1.1 \\
\hline $\mathrm{Ti}$ & 0.03 & $<0.1$ & $<0.1$ & $<0.1$ & 2.8 \\
\hline $\mathrm{Zn}$ & 0.09 & $<0.1$ & $<0.1$ & $<0.1$ & $<0.1$ \\
\hline $\mathrm{Zr}$ & 0.26 & 0.24 & 0.25 & 0.28 & 0.25 \\
\hline
\end{tabular}

SRAT product results suggest that the total manganese content of the initial sludge in the acid calculations may have been overstated slightly.

The SME product elemental composition is given in Table A-2 on a calcined basis. 
Table A-2. SME product elemental wt \%'s calcined at $1100{ }^{\circ} \mathrm{C}$

\begin{tabular}{|l|c|c|c|c|}
\hline & SB6-21 & SB6-22 & SB6-23 & SB6-24 \\
\hline $\mathrm{Al}$ & 4.70 & 4.61 & 4.82 & 4.17 \\
\hline $\mathrm{B}$ & 1.64 & 1.63 & 1.41 & 1.59 \\
\hline $\mathrm{Ba}$ & 0.045 & 0.046 & 0.050 & 0.042 \\
\hline $\mathrm{Ca}$ & 0.225 & 0.233 & 0.269 & 0.265 \\
\hline $\mathrm{Ce}$ & 0.069 & 0.070 & 0.071 & 0.059 \\
\hline $\mathrm{Cr}$ & 0.064 & 0.064 & 0.072 & 0.064 \\
\hline $\mathrm{Cu}$ & 0.043 & 0.019 & 0.046 & 0.038 \\
\hline $\mathrm{Fe}$ & 7.33 & 7.20 & 7.15 & 6.46 \\
\hline $\mathrm{K}$ & 0.08 & 0.09 & 0.08 & 0.06 \\
\hline $\mathrm{La}$ & 0.035 & 0.035 & 0.035 & 0.028 \\
\hline $\mathrm{Li}$ & 2.24 & 2.26 & 2.20 & 2.39 \\
\hline $\mathrm{Mg}$ & 0.21 & 0.21 & 0.21 & 0.21 \\
\hline $\mathrm{Mn}$ & 2.24 & 2.18 & 2.09 & 1.76 \\
\hline $\mathrm{Na}$ & 10.3 & 10.2 & 10.6 & 10.8 \\
\hline $\mathrm{Ni}$ & 0.94 & 0.93 & 0.92 & 0.76 \\
\hline $\mathrm{P}$ & $<0.1$ & $<0.1$ & $<0.1$ & $<0.1$ \\
\hline $\mathrm{Pb}$ & $<0.1$ & $<0.1$ & $<0.1$ & $<0.1$ \\
\hline $\mathrm{S}$ & 0.15 & 0.14 & 0.13 & 0.17 \\
\hline $\mathrm{Si}$ & 22.5 & 22.9 & 23.8 & 23.7 \\
\hline $\mathrm{Ti}$ & 0.013 & 0.014 & 0.052 & 1.018 \\
\hline $\mathrm{Zn}$ & 0.030 & 0.029 & 0.039 & 0.034 \\
\hline $\mathrm{Zr}$ & 0.075 & 0.070 & 0.187 & 0.096 \\
\hline
\end{tabular}

The $\mathrm{pH}$ profiles from the four SRAT cycles are shown in Figure A-1. The period from 13 to 6 hours prior to the end of formic acid addition contains the $\mathrm{pH}$ data for ARP addition at boiling in SB6-24. The probes held calibration to within $0.4 \mathrm{pH}$ units, except for the initial probe in SB6-22 which failed during nitric acid addition and was replaced prior to formic acid addition. 
SRNL-STI-2010-00212

Revision 0

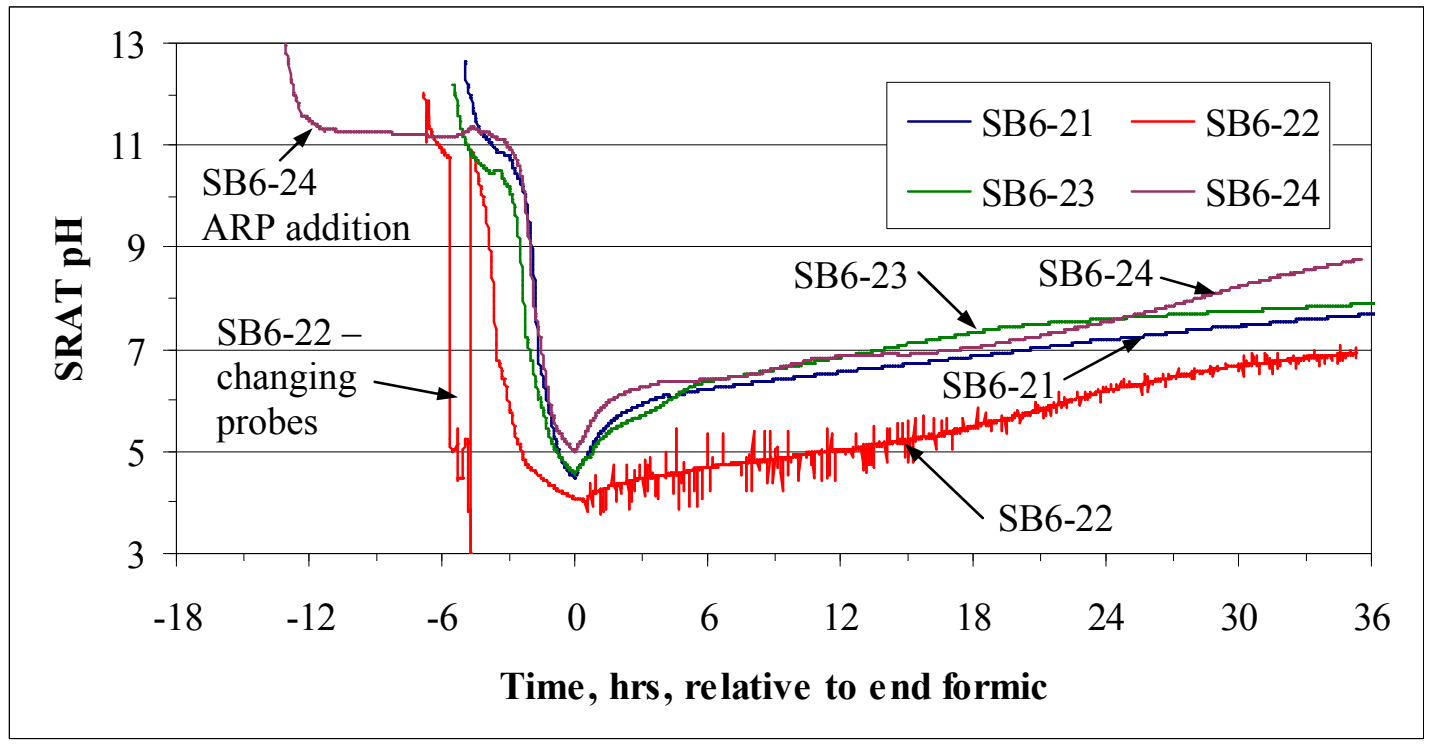

Figure A-1. The SRAT pH profiles for the four tests

Cold PSAL sample data supports nearly a $\mathrm{pH}$ unit difference between the SB6-23 and SB6-24 final SRAT $\mathrm{pH}$ readings (with and without ARP/MCU). Ammonium was found in SB6-22 and SB6-23 SRAT products, but was below detection limits in SB6-24, perhaps due to the higher $\mathrm{pH}$. The SB6-22 pH data became noisy shortly after the end of formic acid addition, and the trend shown may be biased due to ground fault issues. Such issues do not show up in the end of run probe calibration check because the probe has to be disconnected from the data acquisition cable to perform calibration checks. The cold SRAT product $\mathrm{pH}$ of SB6-22 was about one $\mathrm{pH}$ unit lower than the others on the PSAL probe, so the SB6-22 pH-time data are possibly noisy but still valid (it is also possible that there may have been a small mercury amalgam deposit on the probe tip like those found on the agitator impeller and impacting the readings, in which case the probe data indicates deposit formation occurring shortly after the end of formic acid addition).

Some electronic $\mathrm{pH}$ data were obtained on the dilute nitric acid contents of the ammonia scrubber reservoir during the final pair of runs. These data are shown in Figure A-2. 
SRNL-STI-2010-00212

Revision 0

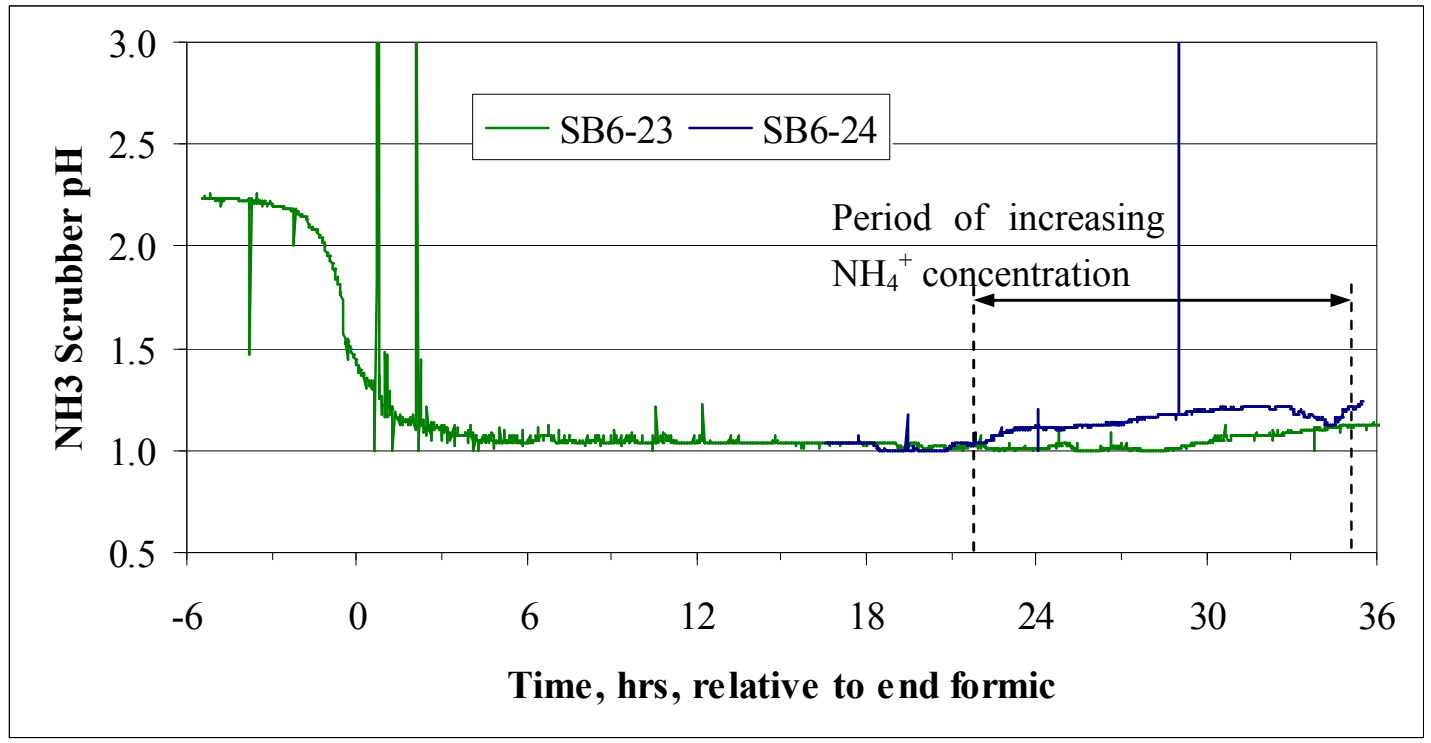

Figure A-2. The ammonia scrubber pH profiles for the final tests

The $\mathrm{pH}$ values from the scrubber reservoirs tended to be noisy on the local monitors, but the data recorded by the $\mathrm{PC}$ only showed a few instances of extreme fluctuations. The starting acid typically had a $\mathrm{pH}$ of about 2.3 for all four runs. Absorption of $\mathrm{NO}_{2}$ during nitrite destruction near the end of formic acid addition dropped the $\mathrm{pH}$ near 1.0 in all four runs. The subsequent absorption of ammonia in SB6-23 appeared to have little impact on the $\mathrm{pH}$, though weak increasing trends are seen in the last 10 hours of the SRAT when data from the ammonia scrubber solution showed increasing concentrations of ammonium ion approaching $1,600 \mathrm{mg} / \mathrm{L}$ at the end of the SRAT cycle.

Data on the SRAT boil-up rate were obtained and logged during these runs. Each step change represents a new measurement of the boil-up rate. Figure A-3 shows the data following formic acid addition. Similar data in appearance were obtained for SB6-24 during ARP addition prior to nitric acid addition. Several small spikes generally represent instances where incorrect data were entered into the boil-up rate calculator on the control PC plus the time it took to reenter the data correctly. 


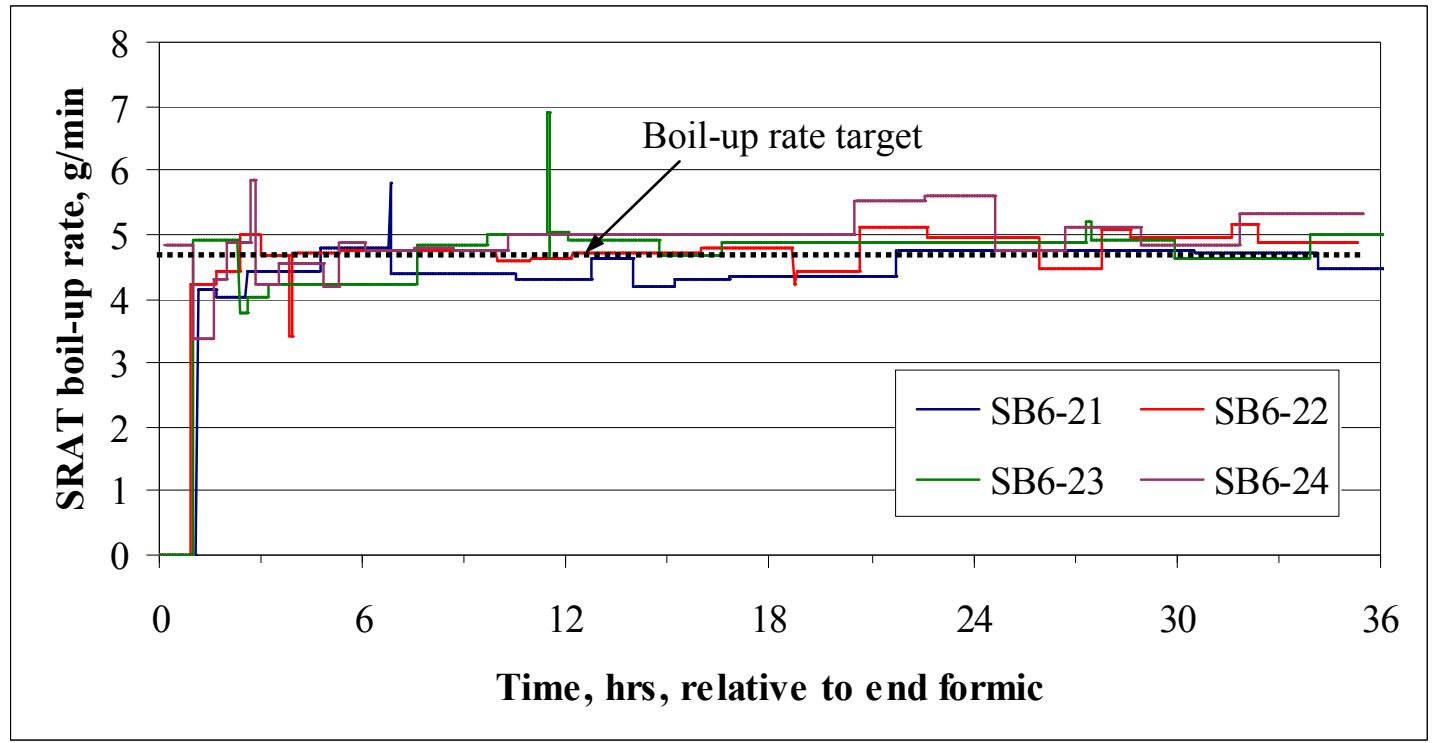

Figure A-3. The SRAT boil-up rate measurement data

The target boil-up rate was $4.8 \mathrm{~g} / \mathrm{min}$, corresponding to $5,000 \mathrm{lbs} / \mathrm{hr}$ in DWPF. The data are presented here in support of the effort to evaluate steam stripping of mercury during the SRAT cycle.

Rheology measurements were made on the four SRAT products and the four SME products. The flow curve data for all eight samples are given below. The four SRAT products are given first. All samples were run in duplicate (runs 1 and 2). The SRAT products were run using the Z41 inner cylinder, while the SME products were run using the Z38 inner cylinder (a larger annular gap to avoid bridging of the gap by frit). Data were taken at $25^{\circ} \mathrm{C}$.

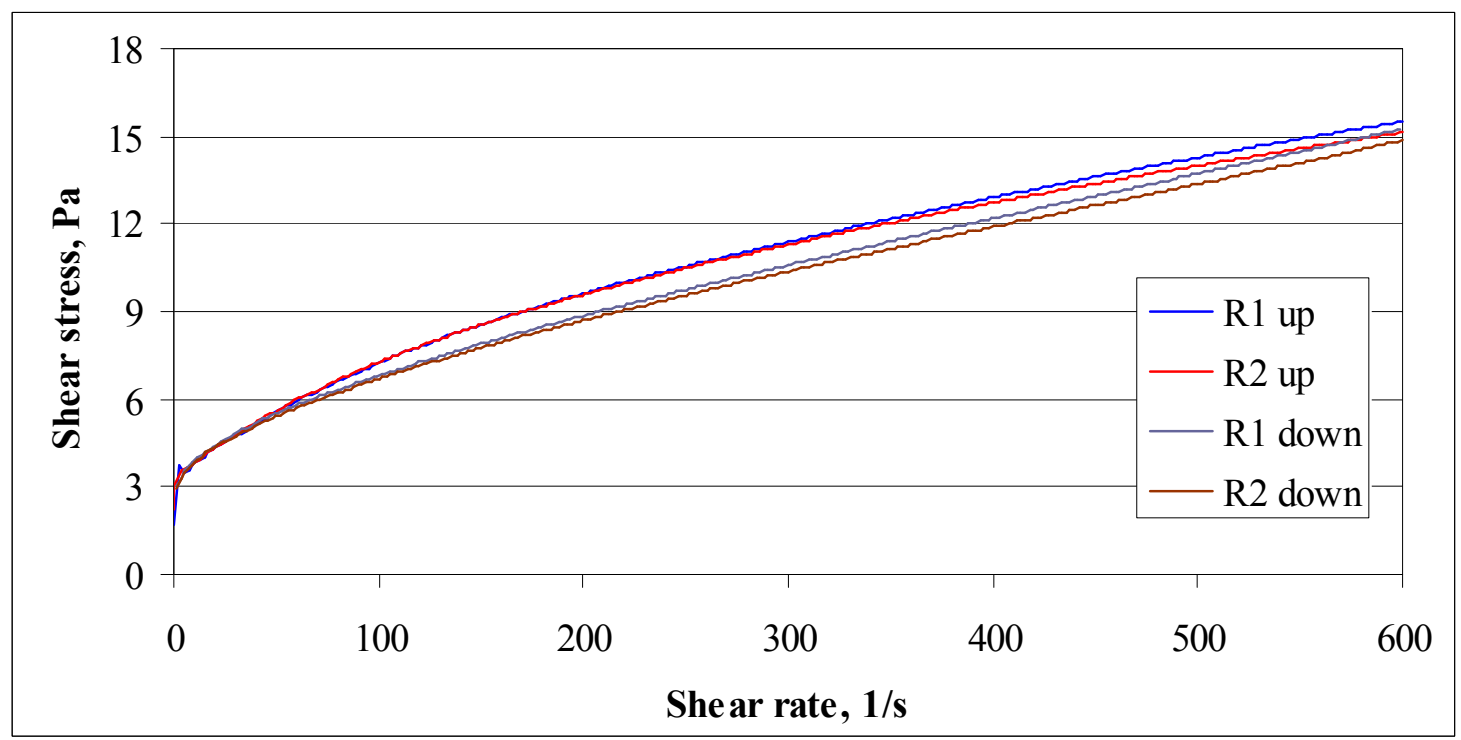

Figure A-4. SB6-21 SRAT product flow curves (duplicate) 
SRNL-STI-2010-00212

Revision 0

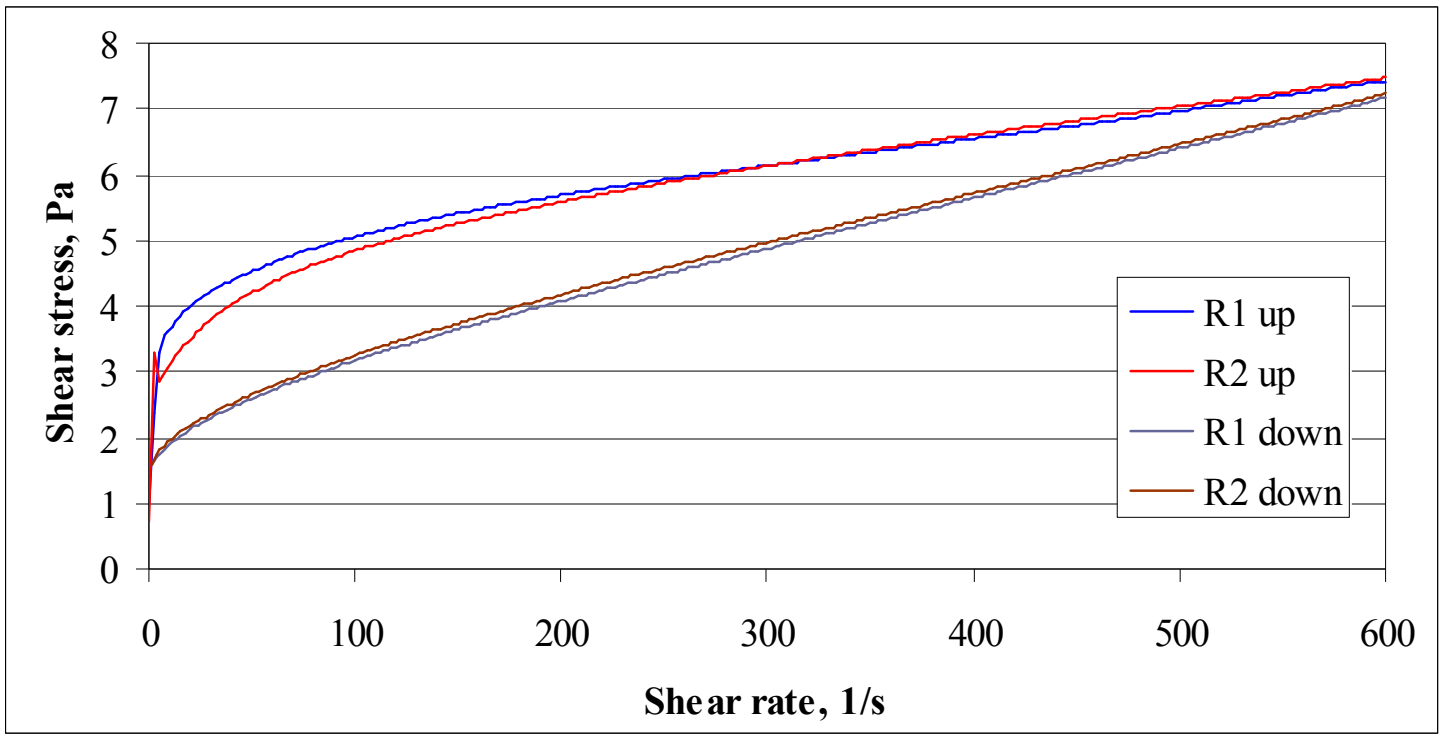

Figure A-5. SB6-22 SRAT product flow curves (duplicate)

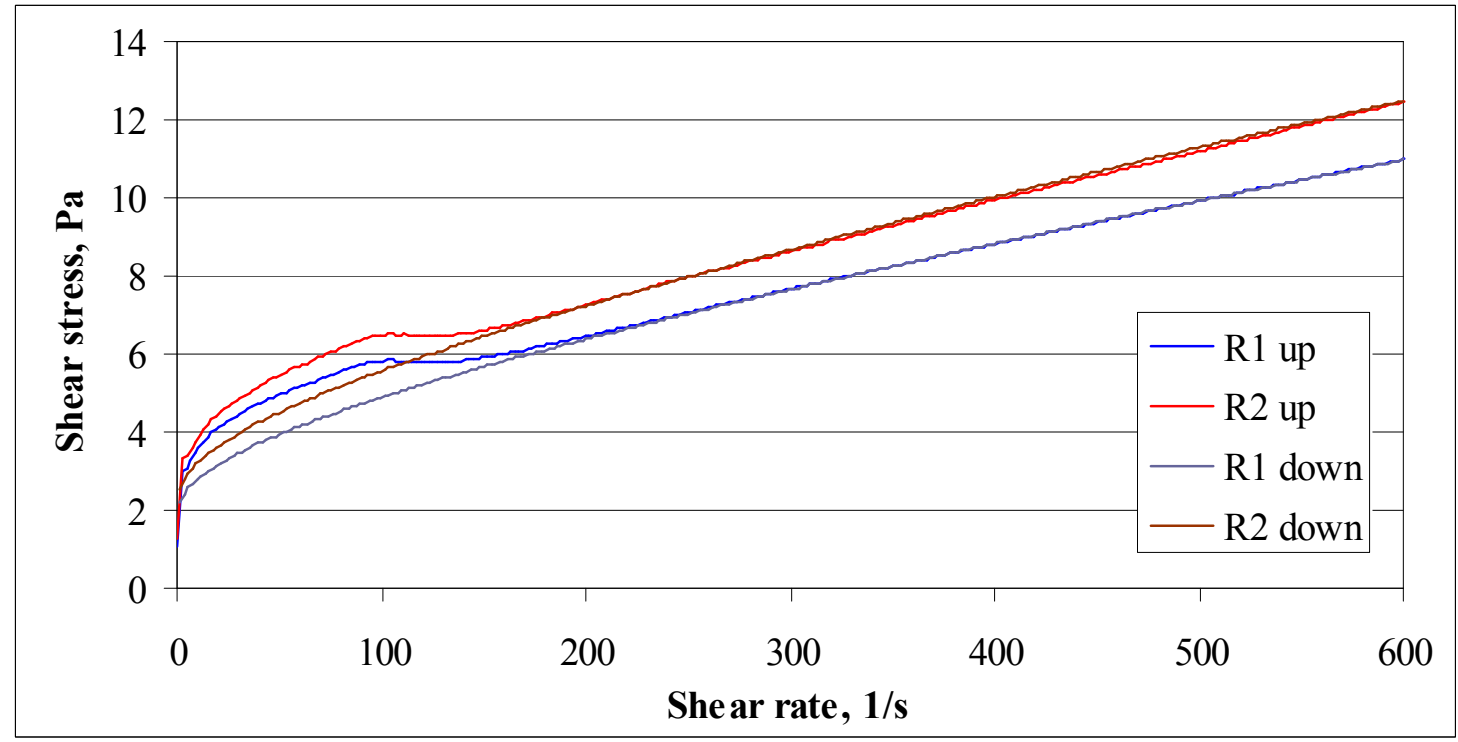

Figure A-6. SB6-23 SRAT product flow curves (duplicate) 
SRNL-STI-2010-00212

Revision 0

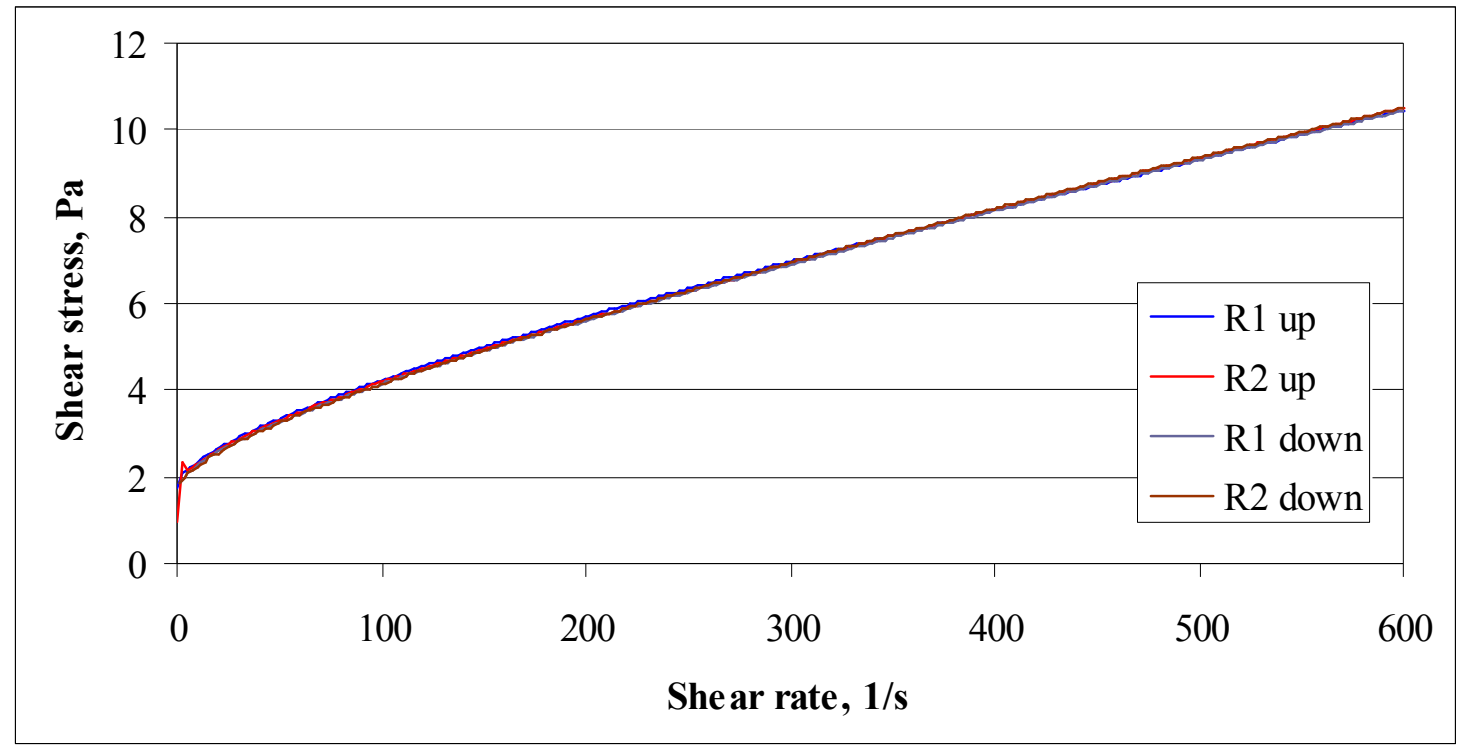

Figure A-7. SB6-24 SRAT product flow curves (duplicate)

The SB6-23 SRAT product flow curves were the only ones that showed any unusual features, and those were relatively minor aberrations at the start of the two up ramps suggesting some shortterm structure formation in the slurry beyond that in the other three cases.

The SME data are given in the next four graphs.

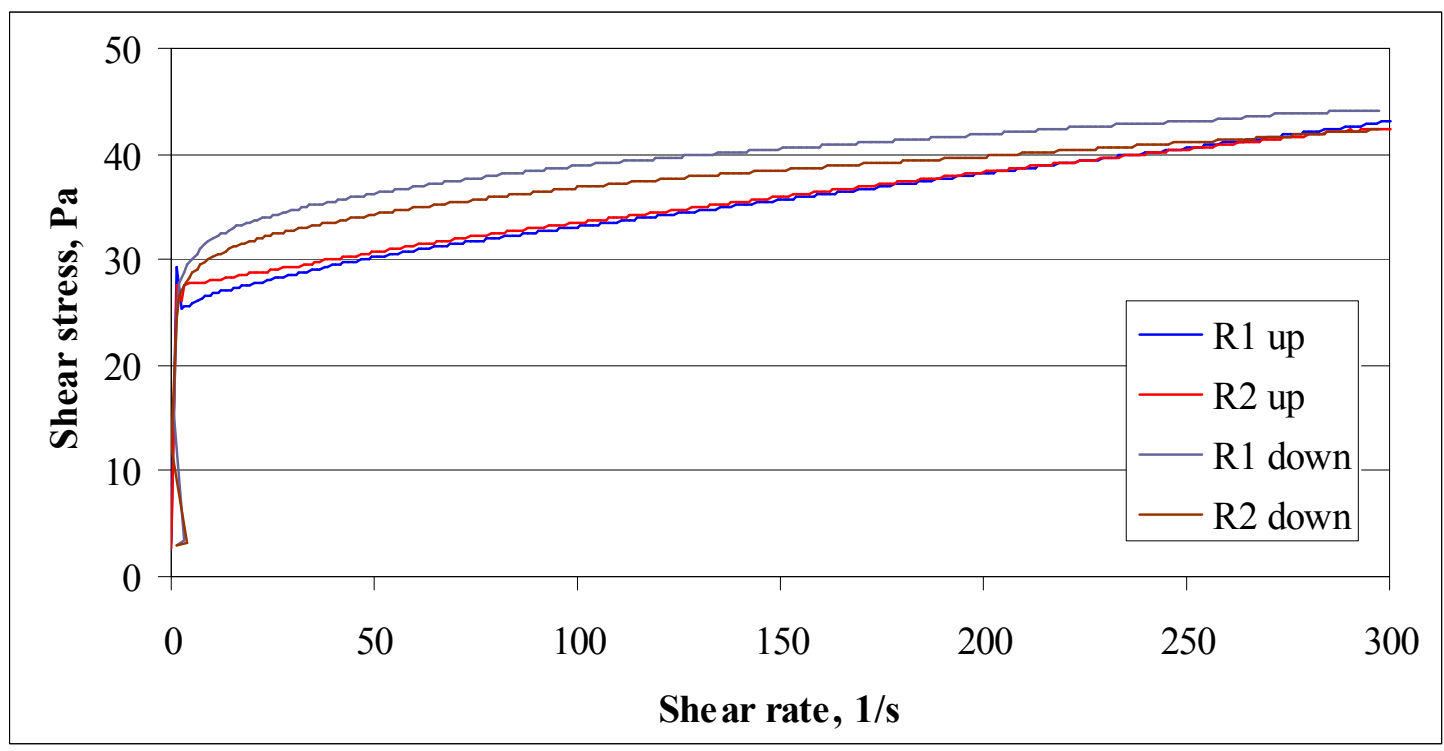

Figure A-8. SB6-21 SME product flow curves (duplicate) 
SRNL-STI-2010-00212

Revision 0

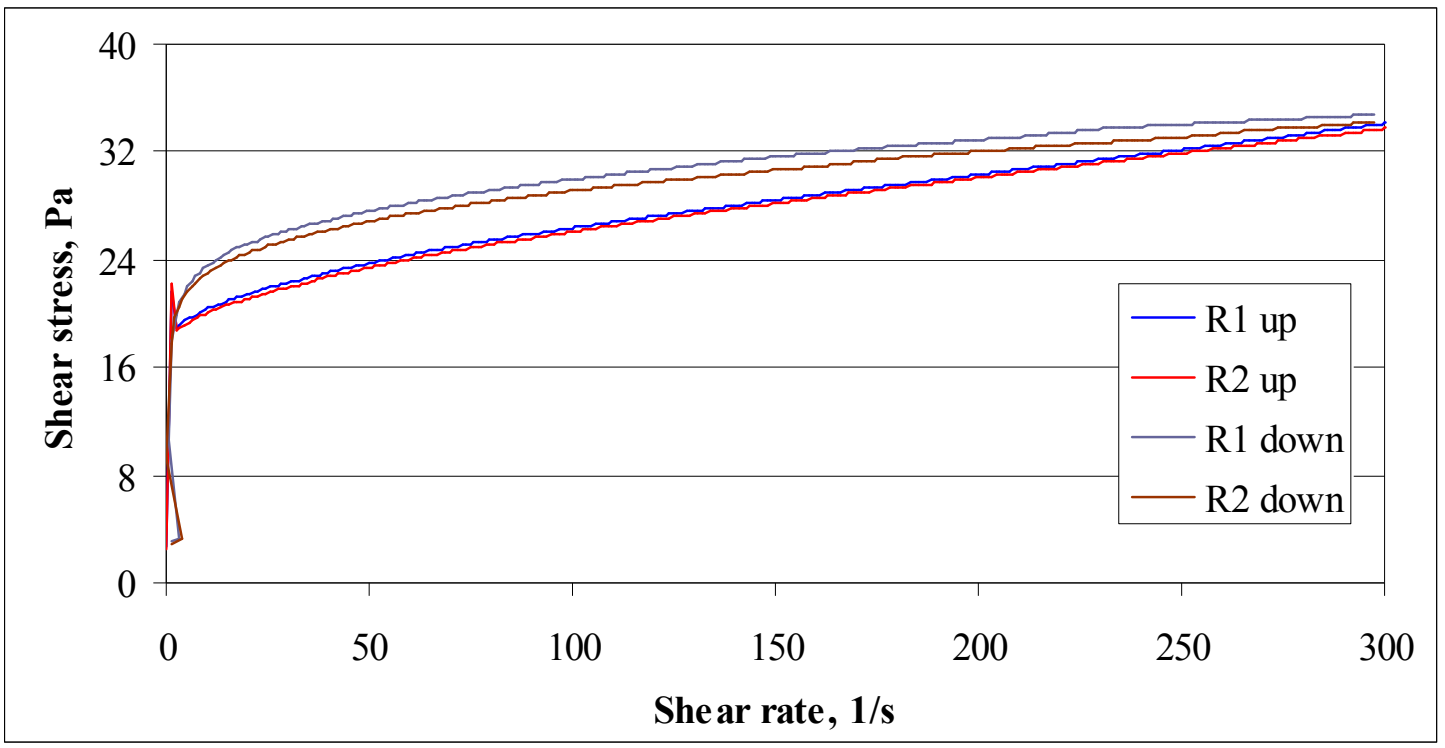

Figure A-9. SB6-22 SME product flow curves (duplicate)

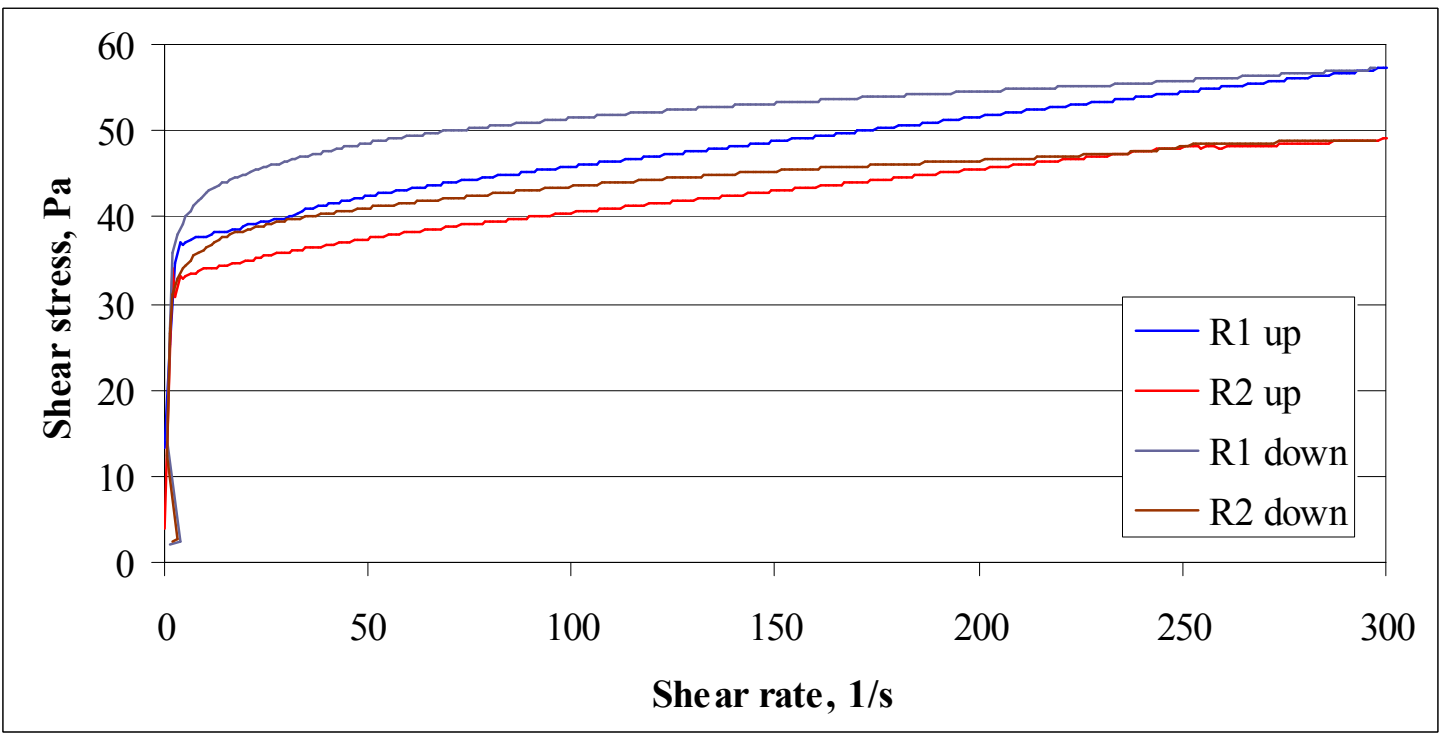

Figure A-10. SB6-23 SME product flow curves (duplicate) 


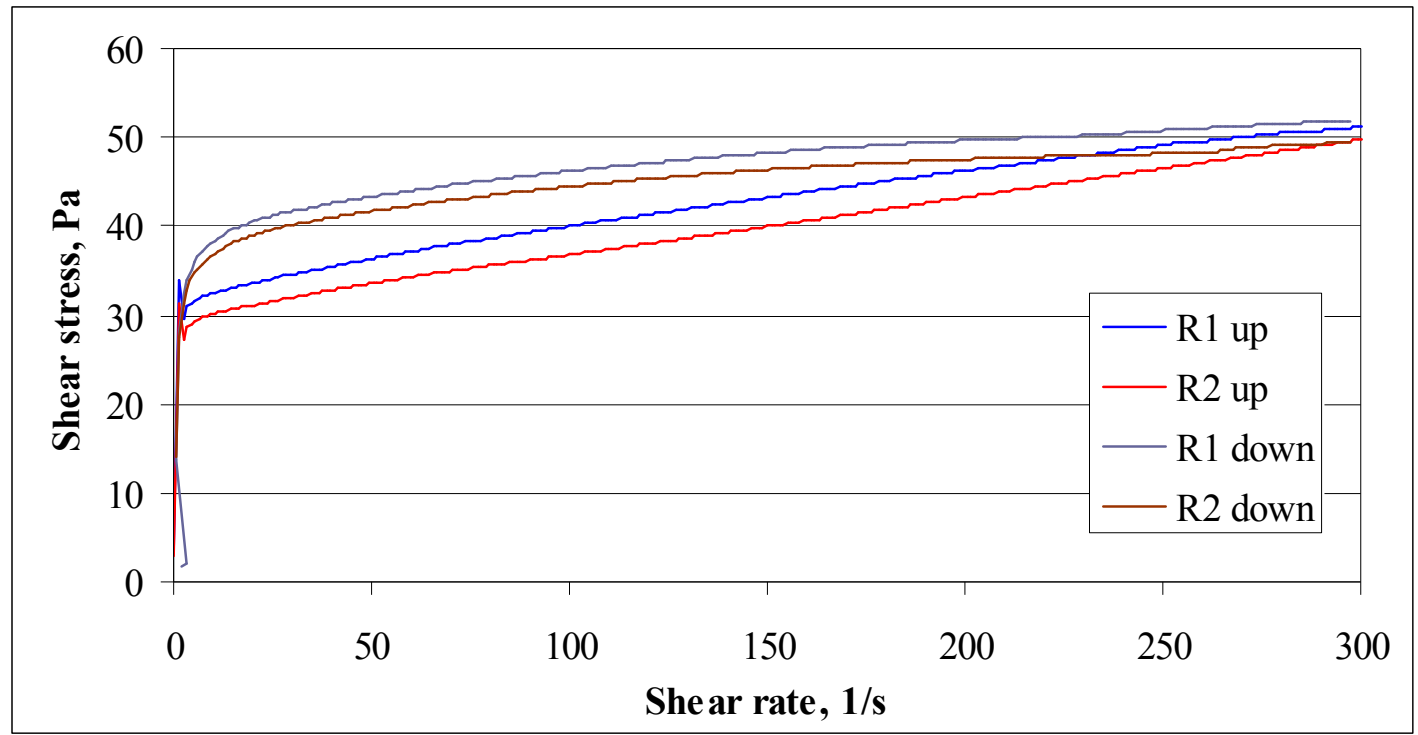

Figure A-11. SB6-24 SME product flow curves (duplicate)

Most of the SME flow curves had the down ramp data above (at higher stresses than) the up ramp data. This pattern has been fairly common for the more viscous samples run at ACTL. Reproducibility of the data in duplicate runs was fairly good, especially when considering the high viscosities of some of the SME products that made the samples difficult to mix prior to loading the cup on the rheometer. An N35 viscosity standard was used to validate the performance of the rheometer before making sample measurements. 


\section{Distribution:}
A. B. Barnes, 999-W
D. A. Crowley, 773-43A
S. D. Fink, 773-A
B. J. Giddings, 786-5A
C. C. Herman, 999-W
S. L. Marra, 773-A
A. M. Murray, 773-A
F. M. Pennebaker, 773-42A
J. H. Scogin, 773-A
W. R. Wilmarth, 773-A
C. J. Bannochie, 773-42A
J. M. Bricker, 704-27S
T. L. Fellinger, 704-26S
A. I. Fernandez, 999-W
J. M. Gillam, 766-H
B. A. Hamm, 766-H
E. W. Holtzscheiter, 704-15S
J. F. Iaukea, 704-30S
M. T. Keefer, 766-H
D. P. Lambert, 999-W
D. D. Larsen, 766-H
D. J. McCabe, 773-42A
R. T. McNew, 704-27S
J. D. Newell, 999-W
J. E. Occhipinti, 704-S
J. M. Pareizs, 773-A
D. K. Peeler, 999-W
B. R. Pickenheim,, 999-W
J. W. Ray, 704-S
S. H. Reboul, 773-A
H. B. Shah, 766-H
D. C. Sherburne, 704-S
M. E. Stone, 999-W
J. R. Zamecnik, 999-W
A. S. Choi, 773-42A 